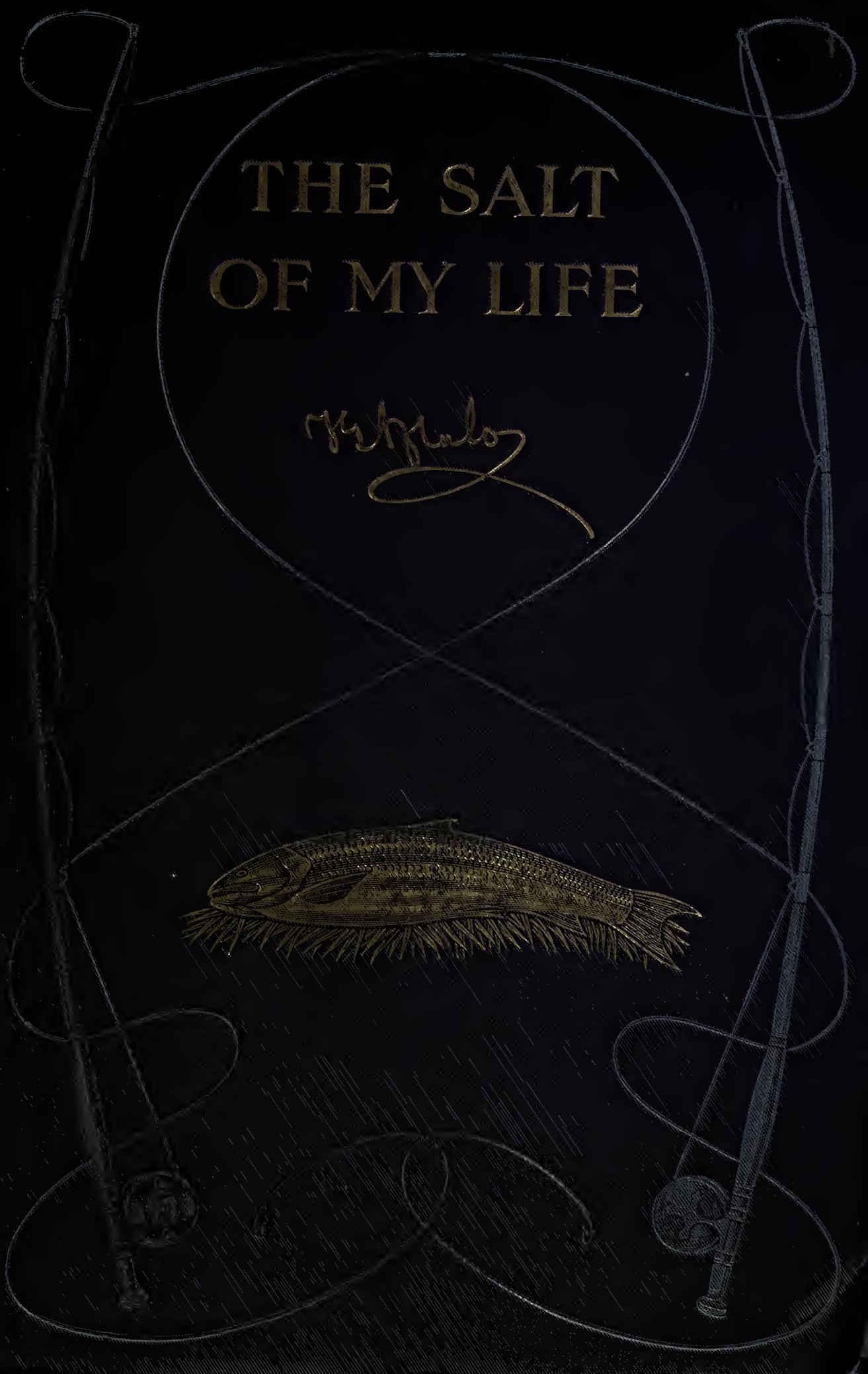




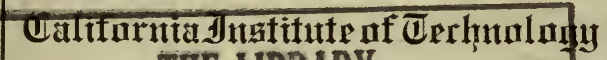 THFupRARY

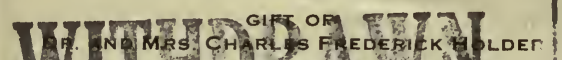

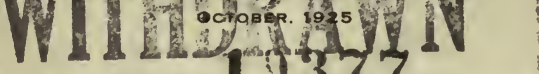

Arrekgian 2 Na.

$19377^{2}$

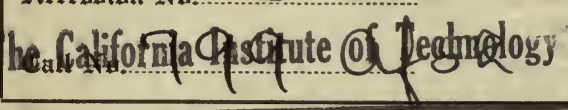

0

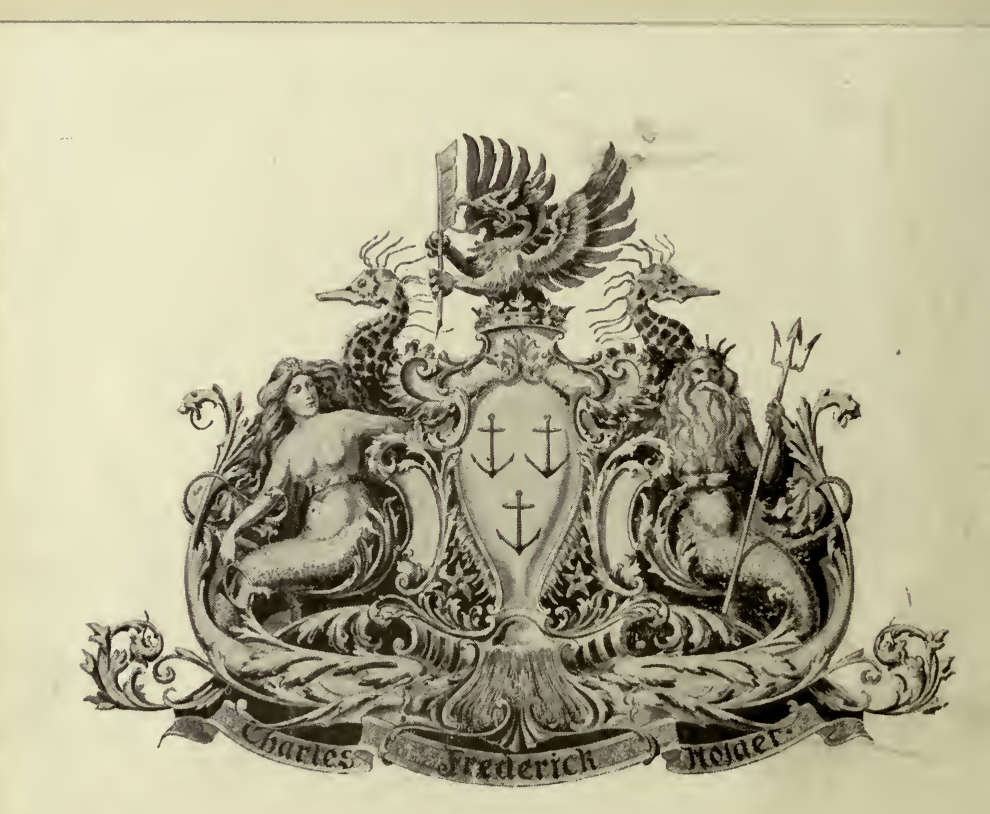

0

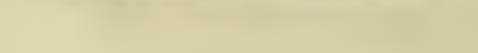

BEREtey GENERAL LIBRARY UNIVERSITY OF

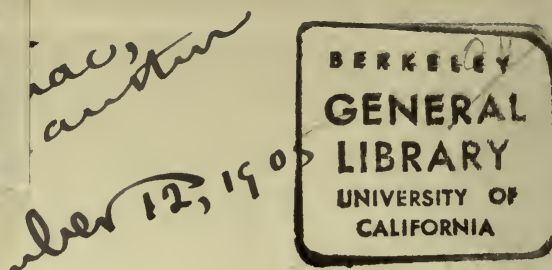

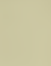

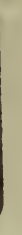

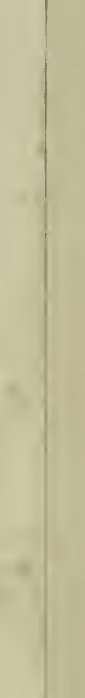




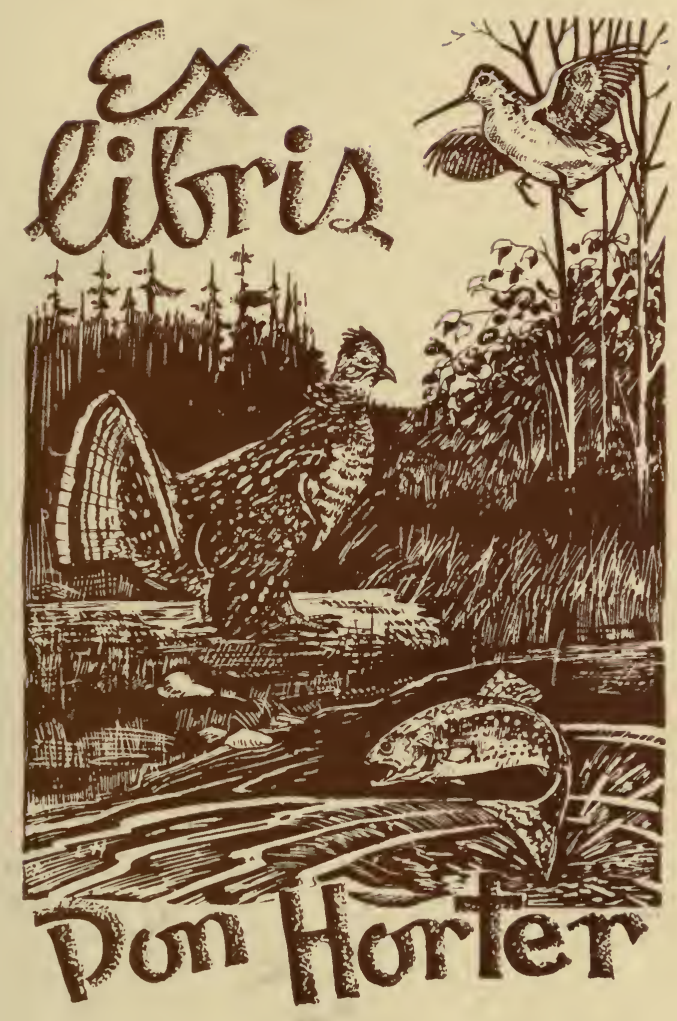


$=$

=

1

$$
\bar{e}
$$$$
1
$$$$
\frac{A}{2}
$$

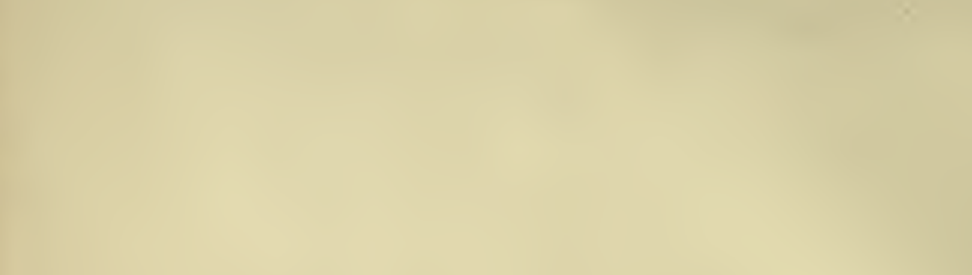

.

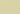


THE SALT OF MY LIFE 


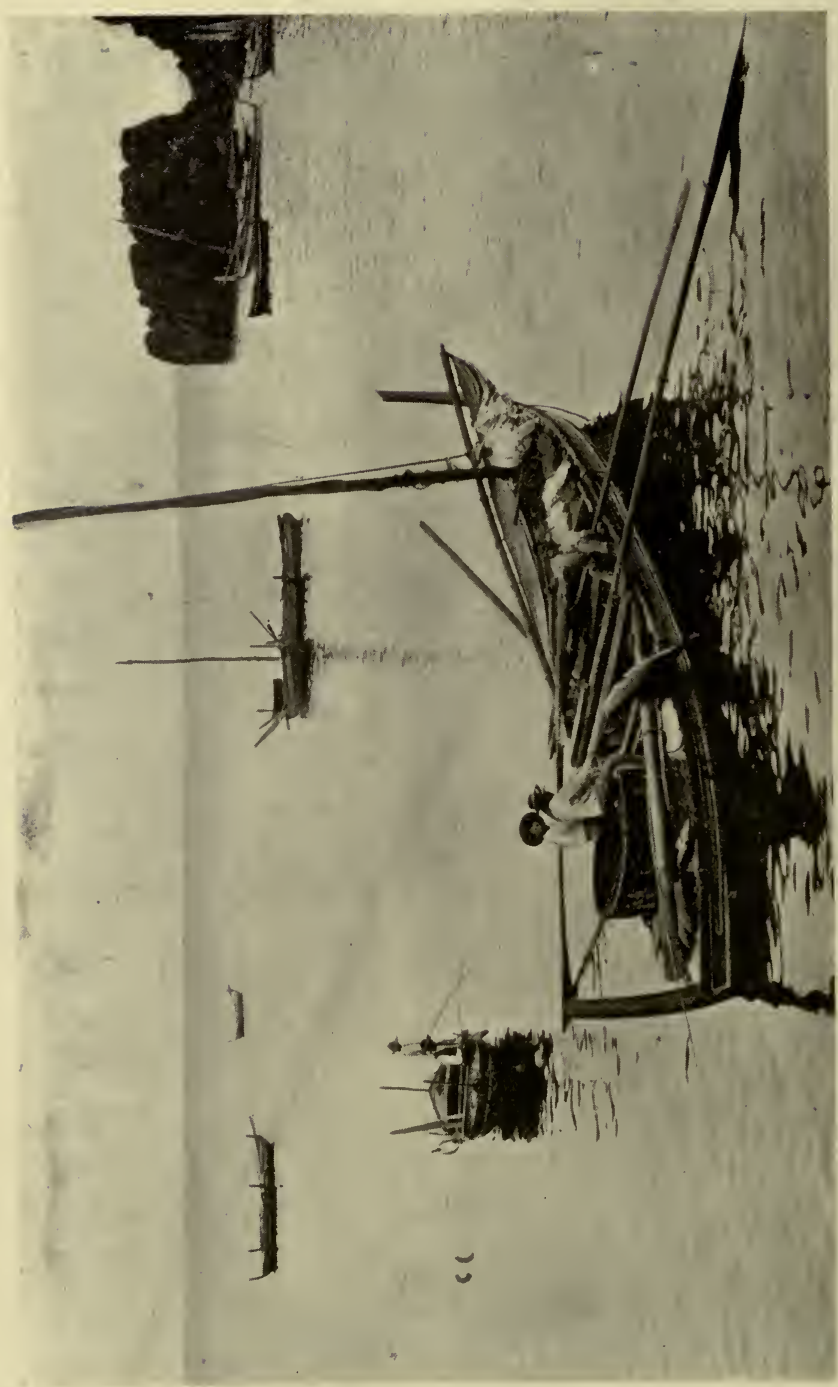

है

点

点

告

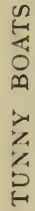

के
है
है
के
के 


\title{
The Salt of My Life
}

\author{
By
}

\author{
F. G. AFLALO \\ F. Z. S.
}

EDitor of the "Encyclopedia of Sport"

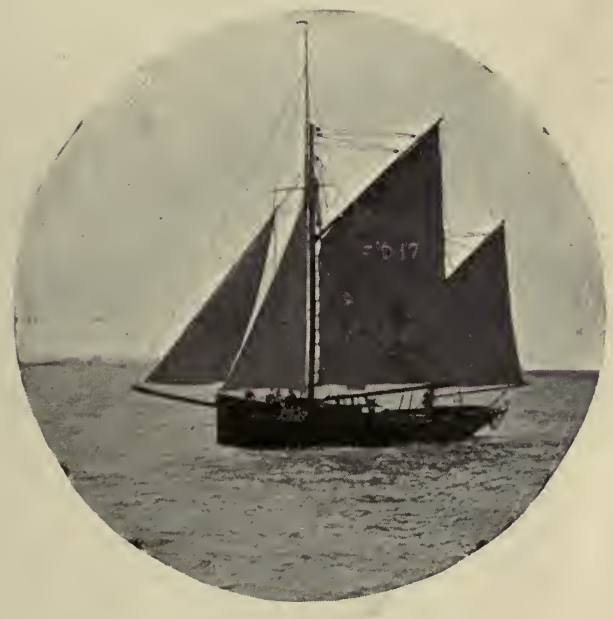

LONDON: SIR ISAAC PITMAN AND SONS, LTD., No. 1 AMEN CORNER, E.C. 1905 
Printed by

Sir IsaAc Pitman \& Sons, LtD., BATH.

(2272) 


\section{SH+39 \\ A355}

\section{THREE QUOTATIONS}

I. "OF such mighty importance every man is to himself, and ready to think he is so to others, without once making this easy and obvious reflection, that his affairs can have no more weight with other men than theirs have with him : and how little that is, he is sensible enough."

\section{Swift: Hints Towards an Essay on Conversation.}

II. "Keep to the personal note throughout the book. . ." Extract from Publishers' Letter to the Author.

III. "He who pays the piper calls the tune."

Old Saying. 
Digitized by the Internet Archive in 2007 with funding from Microsoft Corporation 


\title{
CON'TENTS
}

\author{
CHAPTER I
}

SPEAKING GENERALLY

Apologies for Sport-Otter-hunting-Cost of SportCoarse Fishing-Sport and Food-Popularity of Sea-fishingAngling Competitions-Critics of Sea-fishing-Cases where no Skill is Required-Ways of Catching a Bass-Danger and Discomfort-Sea-fishing in Winter-Night-fishing-Sea-sickness-Pier-fishing-South Coast as Good as Anywhere Abroad

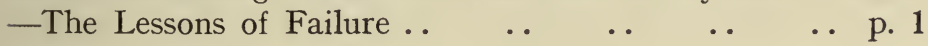

\section{CHAPTER II}

\section{EARLY MEMORIES}

Lowestoft in 1880-Bournemouth Pier, 1881-Hastings in the Eighties-Pout-fishing in Sussex and Cornwall-Originality sometimes the Secret of Success-Pier Crowds-A Conger . caught and a Bass Lost-Sport with a Stingray off AdelaideRambles among the Rocks-Digging Lugworms for BaitThe Unregenerate Use of "Night-hooks"-The Aboriginals of East Sussex-Small Game at Bognor-Wrasse instead of Mullet-Littlehampton-Imaginary Bass in the ArunFishing in Canals-Modern Development of Bournemouth-A Good Bag-Trouble with the Steamers-Rocks in Bournemouth Bay-Dogfish-Pollack-Kent-Ramsgate and a Failure-Deal and Its Competitions-The Admiralty Pier and Other Spots at Dover-Changes at that Port-Early History of the British Sea Anglers' Society. . . $\quad \ldots \quad$. . p. 31 


\section{CHAPTER III \\ BY TIDELESS SEAS}

Two Memories-Warnemünde and Leghorn-A Deserted Pier-River and Sea Together-A German University-Rostock-The Warnow-Tyranny of Professional FishermenAn Expedition after Pike-Fellow Students-The Season at a Baltic Watering Place-Easy Fishing-A Fillet of BreamA Fight with an Octopus-Grey Mullet at Last-A Night with Dynamite Bombs-A Private Mullet Stew-Mr. Sheringham's Bridge-fever-Spearing Murænas by TorchlightA Stroke of Luck at Naples

\section{CHAPTER IV}

\section{POLLACK AND PILCHARDS}

The Charm of Mevagissey-The Realm of the PilchardHard Work of the Fishermen-Our Bag in 1894-A Burning Village-The Late Matthias Dunn-Other Cornish ResortsA Day's Pollack-fishing at Mevagissey-Catching a SharkA Lost Anchor and a Dead Calm-Mixed Fishing nearer Shore-Catching Squid-A Night's Congering-Harold Frederic

$\cdots$

\section{CHAPTER V}

\section{SCHNAPPER AND BLACK BREAM}

Difference of Surroundings-Little Freshwater Fishing in Australia-Sydney Harbour-An Outing after SchnapperFishing in Broken Bay-Fallen Among Sharks-Schnapper and Sundries-Rods Unsuitable-Losing a Big Fish-Bright Colouring of Australian Fishes-Middle Harbour-Black Bream in Still Waters-"Berley"-Blackfish-Rods More Popular in Queensland-Possible Legacy of "Redspinner "Flathead and Jewfish-Sharks and Catfish in Moreton BayCalm-water Fishing-Rock-fishing-Dreadful Climbs-A Relation of Thackeray- "Cungevoi "-A Caution about Seaurchins-Leather Jackets-Failure to catch Hobart Trumpeter and Fitzroy Perch-Shooting Kangaroo and Duck-A Queensland Estuary and Quinine. . . . . $\quad$. p. 127 


\section{CHAPTER VI}

WITH BASQUES AND MOORS

Biarritz in March-Discouraging Reports-A Pelota Match before the King of Sweden-Two Kinds of Broken FrenchGitouche-Toujours D'Artagnan-Good Whiting-fishingPeculiarities of Basque Fishermen-A Little AltercationFishing at Tangier with Abslam-His Fatalism and Patience -With José, who lacked both-Blackmouthed Dogfish at Casablanca-Barbel in the Wad Tensift near Morocco CityWater-tortoises-Grey Mullet at Mogador .. $\quad$ p. 163

\section{CHAPTER VII}

\section{BASS AND MULLET}

Bass and Mullet Compared-Luck of Young FishermenA Mullet Caught on Pollack-tackle-Another on a LegerThe Bass in Two Different Moods-Night-lines-Better Sport on Live Bait-Attractions of Fishing in Estuaries-A Morning's Sport in the Teign-Memories of that River-Difficulties with Buoy-chains and Weeds-Trouble with other Fishermen -Remedies Indicated-Bait Not Always Procurable-The Grey Mullet-Its Appetites and Habits-My Repeated Ill Luck-Visit to Mr. Gomm at Margate-Experts beneath Margate Jetty-A Day's Success-Importance of Groundbait -A Mullet at Last-Importance of Local Guidance with Mullet and Bass

p. 177

\section{CHAPTER VIII}

\section{A FORLORN QUEST AND SOME COMPENSATIONS}

Success and Failure-Welsh Adders-Other Failures : Arun and Teign Mullet-Poole Bass-Bexhill Cod-Lulworth Pollack-Eddystone Whiting-Sydney Grouper-Queensland Perch-Maldon Brill-The Worst Failure of all: Madeira 
Tunny-Origin of Plan to Catch them on the Rod-Preparations and Arrangements for the Trip-Arrival at FunchalOur First Outing-We catch a Turtle, but no Tunny-Our Second Failure-We Follow the Tunny to Porto SantoCamp three nights on the Ilheo de Cima-With C. B. Cossart Fishing in the Rock-pools-Barbary Type of Our FishermenBringing Spiders Home for the Zoo-We Catch a Variety of Fish in Trammels-Other Rod-fishing: Sargo-fishing at Sunset-Novel Way of Getting Crab-bait-The Birds of our Island-Padre Schmitz-Trailing for Garoupa-A Last Try tor Tunny-A Rough Sea for Fishing-Chances of Catching Madeira Tunny on the Rod-Different Classes of TunnyDifficulties-Mr. Holder's Advice-Fishing for Mackerel and Muræna at Funchal-Torches and Groundbait-An Incanta-

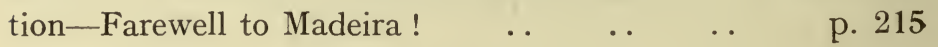

\section{CHAPTER IX}




\section{LIST OF ILLUSTRATIONS}

PAGE

Tunny Boats off the Coast of Madeira ... Lazy Mackerel Fishing ... $\quad \ldots \quad \ldots$ The Pier Fisherman $\quad \ldots \quad \ldots$... The Peaceful Scenes of River Fishing ... Low Tide in the Harbour Hastings Pier

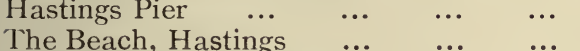
Hastings, from the Cliff $\begin{array}{llll}\ldots & \ldots & \ldots & \cdots\end{array}$ Early Morning at Folkestone $\quad \ldots . \quad \ldots$ Ramsgate at Daybreak ... $\quad \ldots \quad \ldots$ The Rocky Shore $\quad \ldots \quad \ldots . \quad \ldots$

A Muræna on the Rod $\ldots \quad \ldots . \quad \ldots$ Mevagissey : the Pool $\ldots$... $\quad \ldots$ Mending the Nets $\quad \ldots \quad \ldots \quad \ldots$ Mevagissey Quay ... $\quad \ldots \quad \ldots \quad \ldots$

$\begin{array}{lllll}\text { The Schnapper } & \ldots & \ldots & \ldots & \ldots\end{array}$

$\begin{array}{lllll}\text { The Nannygai } & \ldots & \ldots & \ldots & \ldots\end{array}$

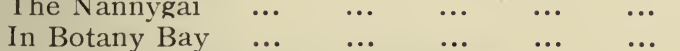
... ... Frontispiece

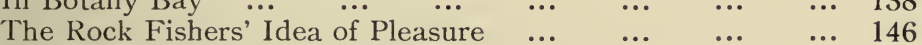

Catching Shad in the Um Erbeya $\quad \ldots \quad \ldots \quad \ldots \quad \ldots \quad \ldots 165$

A Bridge over the Tensift, Morocco City $\quad \ldots \quad \ldots \quad \ldots \quad \ldots 17$

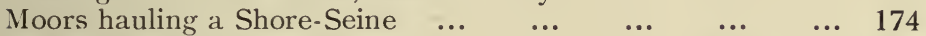

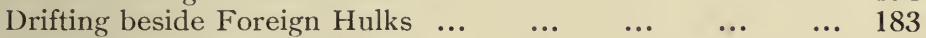

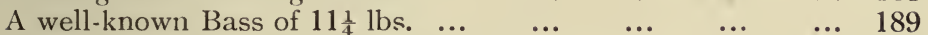

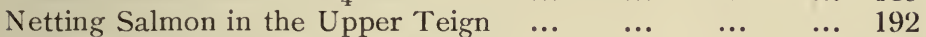

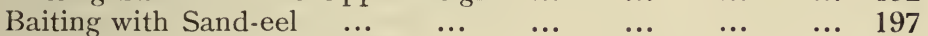

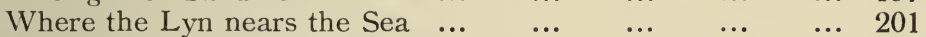

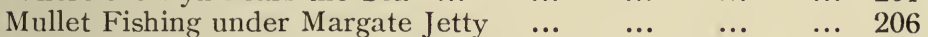

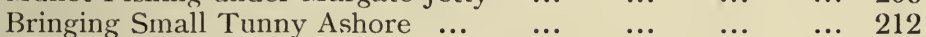

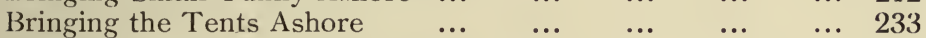

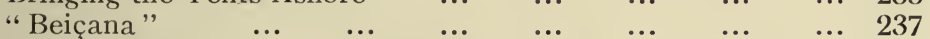

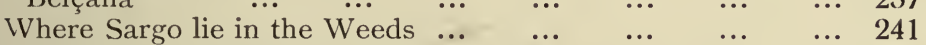

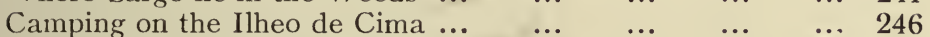

$\begin{array}{llllll}\text { Tunny Boats at Cama de Lobos } & \ldots & \ldots & \ldots & \ldots & 246\end{array}$

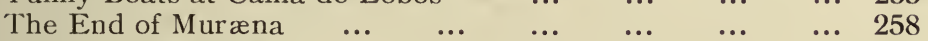

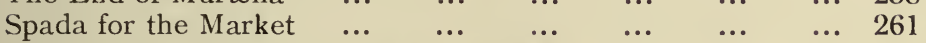

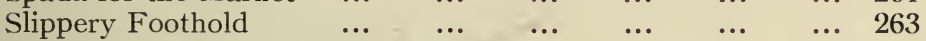

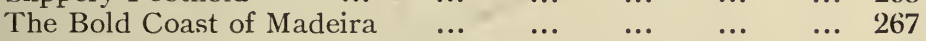

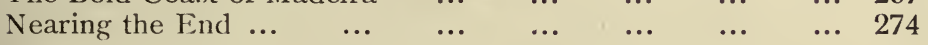





\section{THE SALT OF MY LIFE}

I

SPEAKING GENERALLY

Apologies for Sport-Otter-hunting-Cost of SportCoarse Fishing-Sport and Food-Popularity of Sea-fishingAngling Competitions-Critics of Sea-fishing-Cases where no Skill is Required-Ways of Catching a Bass-Danger and Discomfort-Sea-fishing in Winter-Night-fishing-Sea-sickness-Pier-fishing - South Coast as Good as Anywhere Abroad -The Lessons of Failure.

AN honest Scotsman once sat in a bar at Huddersfield and listened with ill-concealed impatience to the shallow pretexts with which one apologetic tippler after another addressed himself to the ladyin-waiting. The first, it seemed, suffered from a sudden pain in his head; the second had been compelled to work and forego his sleep the night before; a third had only that moment been the recipient of news of a family bereavement.

"Miss," roared Donald at length, when he could stand it no longer, "just gie me a dram o' whisky-because I LIKE IT!”

Outspoken. Donald always comes to my mind whenever I hear a sportsman apologising for his $2-(2272)$ 
love of fishing, shooting, or hunting. I should not dream of apologising even for having once had ideas about the beauties of otter-hunting, though for me its joys are of the past. I have seen it north and south. I have driven across the Menai Bridge with the late Mr. Assheton-Smith; with whom I was staying at Vaynol, at an hour when we should both have been better in bed. The whole forenoon we scoured the ponds and streams of Anglesea for an otter that may, or may not, have existed there. I have no good reason for supposing either that it did, or that it is not there still. I once walked with that crack pack, the Culmstock, fourteen miles in a downpour of rain, round Bolham Weir and Bampton. Strange to say, hounds did not find on that occasion. Next week I was out with the Dartmoor. Hounds found a water-hen.

In spite of the outcry against "mudded oafs" and "flannelled fools," sport, which does not necessarily mean dreaming of other people playing cricket, or backing horses without ever going to a race, seems in some form or other necessary to the primitive, well-balanced mind. Though a good sportsman should not grudge his hobby what he can reasonably afford without prejudicing the interests of those dependent on him, the amount spent is no gauge whatever of the sportsman. A passion for riding may be indulged by playing polo 
at Hurlingham or pony-racing over Ramsgate sands. As good fishermen sport with roach on the Lea as with salmon in the Tay. Dives shoots stags, and Lazarus rabbits, but each can play the game; nor is he who drives a 70 horse-power motor necessarily a better sportsman than his poorer neighbour who drives a 1-horse-power dog-cart. These are platitudes, yet they are often ignored. While some games, like hockey and football, seemingly afford little range of expenditure, others, like golf or polo, can obviously be adapted to a variety of income.

In the sport of fishing, the range of expenditure is a very wide one indeed. The ambition most costly to gratify is the command of high-class trout-fishing in the vicinity of London. Indeed, both trout and salmon are expensive objects for the angler, unless he is prepared to travel in search of them far from the comforts of civilisation, spending time and money on the journey and seeking his sport in remote northern lakes and rivers so inaccessible to the world's business centres as to be not yet overfished. The cheapest fishing in this country is that known, somewhat unfortunately, as "coarse," a term used by naturalists to distinguish members of the carp family, eels and one or two other groups from the "game" salmon and trout and their kind. No offence whatever can have been intended towards 
those who, from choice of necessity, angle only for the "coarse" fish, seeing that Izaak Walton himself dubbed the carp "Queen of Rivers," and drew his companion's attention to the choice sport afforded by barbel. It perhaps needs no argument to shew that the habits of the tench and eel may fairly be described as "coarse" by comparison with those of the Salmonide, while as food, at any rate in any hands but those of a German cook skilled in the dressing of freshwater fish, most of the "coarse" fish are contemptible.

The precise extent to which considerations of the cuisine should have weight with the sportsman in choosing his quarry is always a debateable question, and one that hardly gains much by discussion. On the one hand, the old foraging spirit, in which Esau went forth after venison, burns in every sportsman, while the most plausible platform justification of game-preserving is that it cheapens game in the food-market. On the other hand, we eat neither otters nor foxes, and if any justification has to be given for the field-sports of which these are the objects, it has to take the shape of a rather questionable appeal to the damage they do as vermin of the farm or troutstream, a feeble argument of which the critics of sport are not backward to make capital. On the other hand, we have the undeniable fact that, as the little girl retorted when reproved for eating 
a wasp alive, tastes differ. There are not in British seas three fishes that give the fisherman better sport than the bass, pollack and grey mullet, yet not one of them, save perhaps when quite small, is to my mind pleasant eating, though some folks appreciate them, and I never find any difficulty in giving them to grateful friends. Food, however reasonable a motive of sport, has long ceased to count for much, and there are few anglers so successful that they could not buy at marketprice as much as they catch for a fraction of what it cost when caught for sport.

In the matter of the expense entailed, sea-fishing probably ranks midway between the two kinds of sport previously named. On the one hand, it is free from the heavy rentals charged for stretches of salmon-water; on the other; it can rarely be regarded as quite rent-free, like, for instance, roach-fishing from the banks of Thames or Lea, because, unless pursued from a crowded beach or an overfished and disturbed harbour, there is usually something to pay for admission to a pier or hire of a boat. The sport is a development of comparatively recent date. Twenty years ago, anyone who unpacked a rod on a pier was almost as certain of drawing a crowd as if he had produced a performing bear. To-day, a score of rods wave unnoticed from the piers at Deal, Brighton, Plymouth and a hundred other resorts 
east and west, while the old-fashioned throw-out line is less in evidence every year. Influential clubs, societies, federations are established round the island, and anglers assemble at the different watering-places to take part in monster competitions. Of such functions the patient reader of what follows is asked to expect no account. I was never present at an angling competition and there is no reason for supposing that I ever shall be. It would be ungracious, and it could serve no useful purpose, to criticise meetings which give great pleasure and do little harm. I simply do not like them and therefore stay away.

In view of the hold which it has of late years taken on the public, apology for sea-fishing is no longer looked for as it used to be. Occasionally, of course, it is still named in clubs with a snort of contempt. Most clubs cultivate a species of Culex, which buzzes around on hot afternoons and irritates its neighbours. There is no bye-law which empowers the committee to get rid of obnoxiously dogmatic members who were so ingenious as to reserve their opinions until elected, and the only thing is to put up with them. I was tackled in this way in a provincial club not long ago by a man whose only sport, as I afterwards learnt, was occasional golf of the foozling order. $\mathrm{He}$ had nothing else to do one morning and evidently thought that I was similarly employed, 
so he introduced the subject by saying that he heard I was an enthusiastic sea-fisherman, and

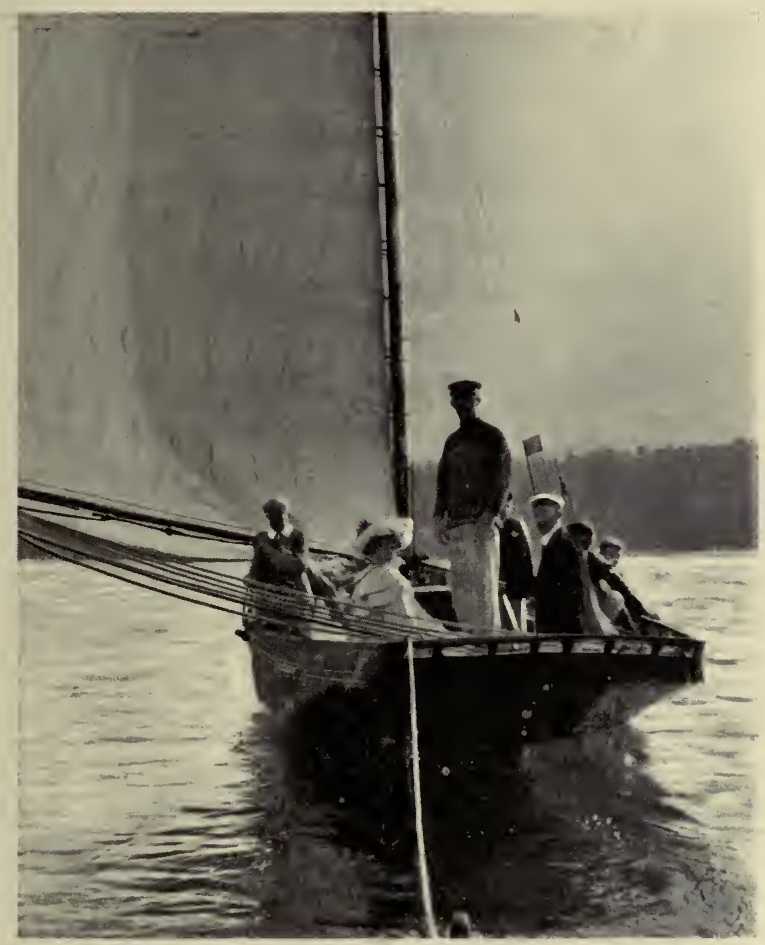

LAZY MACKEREL FISHING

that sea-fishing required no skill. The matter was not argued to a conviction, and I have since met him only in the hall.

As a matter of fact, there are some forms of 
sea-fishing, in which skill is at a discount, but to class in one category every style of salt-water angling is about as reasonable as bracketing deerstalking and pigeon-shooting from traps.

Fishing for mackerel from a sailing-boat, or "plummetting" as it is called on parts of the Cornish coast, is one of the modes in which no skill is required. A heavily leaded line is towed astern, and the way on the boat hooks three mackerel out of four that tamper with the bait. All the fisherman has to do is to haul in the line the moment he feels a fish on it, take the mackerel off the hook, put on a fresh bait if necessary, and fling the lead over the side again. Shelling peas is a problem to it! As a means of picking up fresh bait on the way out to the pollack-grounds, this manner of fishing has its uses, and it may even amuse those with whom a sail occupies the same position with regard to fishing as, with so many hunting folk, a gallop with regard to venery ; but it cannot by any stretch of the imagination be seriously reckoned as artistic sport. Very little higher in its demands on skill is the old style of hand-lining for small pout or whiting. You bait the hooks (unless you prefer to let your boatman do so) and let the lead run out till it touches bottom; then you haul in the obliging fish that hook themselves on. Worse in a measure than either of these is the too common practice of baiting 
a hook, throwing the line out from a pier-head, and leaving it to take its chance, trying it every few minutes to ascertain if any fish is fighting for its liberty at the other end. Most of us have, it must be admitted, fished in this unsportsmanlike manner in unregenerate days, but there is very little more skill or sport in such ways than in the setting of night-lines.

Yet the existence of such practices should no more condemn sea-fishing generally than some ways in which poachers use guns should cast discredit on shooting. The old style of fishing with handlines, which may be found in caricature in back numbers of Punch, is no longer in general favour with those who make a study of the sport. The variety of ways in which, for example, the bass may be caught by the fisherman will compare favourably with that associated with any fish. I do not for one moment contemplate instituting comparison between the bass and the salmon, for I know far too little of the latter fish for such comparison to carry any weight. Of the bass alone it suffices to say that it may be taken on a fly, on live bait, with dead bait, or on a spinner. The dead bait may be used with floattackle in mid-water or with a heavy lead on the ground. The fish may be sought from piers, from rocks, from beaches of sand or shingle, in sheltered estuaries or in the open sea, at high tide, 
low tide, or any time between. Since it is caught at sea, as well as in rivers, it gives an even greater range of situation than the salmon, whose wanderings in salt water are still a profound mystery. We catch it only in our rivers, at a period when, paradoxically enough, it is not feeding in the normal sense of the word ; during the remainder of the year it is putting on flesh very rapidly, living probably in water too deep for either trawlers or hooks to disturb it. The bass, it is true, is not taken in our estuaries at all times, but less mystery attends its absence from the shallows, since it is taken in the trawl almost all the year round. As, moreover, it enters estuaries in pursuit of small fishes, and not for spawning purposes, its movements are less regular. Thus, in the River Teign, in Devonshire, more detailed reference to which will be found later, we did not, during the five summers 1900-4, catch more than a few small fish before the second or third week of June, whereas in the present summer (1905) a resident angler and his boatman made a catch weighing in the aggregate $40 \mathrm{lbs}$., largest fish $4 \mathrm{lbs}$., during the last week of May, the continued warm weather of the previous fortnight having doubtless accelerated the arrival of the brit shoals, to prey on which the bass come inshore.

The bass has been selected as a type of fish that is many things to many men, but the same 
might be said of the pollack or mackerel, either of which will, under suitable conditions, take the same variety of natural or artificial baits, though both are fish of the open sea, rarely entering brackish water.

These three fishes alone prove how erroneous it is to speak or write of "sea-fishing," derisively or otherwise, as if there were any homogeneity in so protean a sport. There is not more difference between mayfly-fishing for trout and babbing for eels than between, let us say, handline-fishing for conger at midnight and bass-fishing with a trout-rod at mid-day, or between using a stout line and heavy lead for schnapper on Australian reefs and throwing a single fly for billet into the deep water alongside Filey Brigg. No man with any sense of logic could speak disparagingly and collectively of all these styles of catching sea-fish as requiring no skill.

Two considerations appear to have prejudiced the sport of sea-fishing in the eyes of many people, who might otherwise have learnt its delights, and these are the fear of danger and the impatience of discomfort. As a matter of fact, the danger may usually be avoided with a little care; and discomfort is, after all, a relative term, for what irks one man leaves his fellow unmoved. No one can prevent, or always even anticipate, a sudden squall in apparently fair weather, but there can 
rarely be any need to start from shore with the least evidence of a coming change in the sky. Certain simple rules of safety also govern the manner of getting in and out of boats, of launching or returning on open beaches, of climbing over slippery rocks, or of handling such fishes as are armed with spines willing to wound and not afraid to strike. Now and then one meets with a man who wilfully disregards these precautions and reckons himself a better sportsman for doing so. (In reality, that word "sportsman " is sadly in need of revision. Indeed, I am looking forward with curiosity to its definition in the New English Dictionary now in course of publication.) Such a man is a fool, and for folly like his there is but one remedy. Whether your sport be motoring, big game shooting, or skating, danger should always be avoided where possible. There are but two forms of recreation in which to court it is to command applause; these are mixed hockey and football.

Discomfort, as has already been said, means differently to different people. The luncheonbasket does not as a rule contain champagne and truffles, but it may do so without having any prejudicial effect on sport, provided you catch your fish first and lunch on the way home. The smacks and luggers, in which we usually go a'fishing, are not as a rule fitted out in imitation 
of His Majesty's State Barge, but they may be so decorated to order. Of the little discomforts which no expenditure will avert, a little salt water on the face and hands should hurt no one; and those who go sea-fishing in clothes that they mean to use ashore deserve all they get. The seat up to windward, the sudden duck of the head when the sail comes over, may not make up the comforts of a camp-stool in a Thames punt, but the brisk sail is more health-giving.

At the same time there are forms of discomfort, for which I confess to having parted with my earlier enthusiasm. Fishing in winter and fishing at night time are for me only rare experiences where once such zeal was chronic. I have done that winter-fishing with the maddest ; blown on my fingers before daybreak on Deal pier and knocked the rime off my sea-boots in many a boat that cleaved wintery seas, but ever since my return from the Australian Colonies I saw no humour in such sallies, and my fishing has been an intermittent idyll of summer seas and estuaries, with corn on the hills, not snow, with the shriek of the swifts in my ears, not the calling of wildfowl, with early sunrises and long, warm sunsets, not with that hurried transition between day and night that chills those whom it finds on the water. Everyone to his taste. I bask in flannels, others shiver in tarpaulins. True, I have to give 
up fishing for half the year and give the cod and whiting the go-bye but I am content to amuse myself for the other half with bass and pollack, mackerel and mullet, and then send my rods to the maker. I must own to having an alternative amusement for the short days, thanks to the kindness of friends, whose hospitality stands the yearly test of a more than averagely miserable performance with the gun. Were it not for such interludes on the moors, among the roots, or beside the coverts, it may be that the sulking cod and hungry whiting would still win me forth as they did of yore, but for ten years at any rate their spell has not worked, and a predisposition to rheumatism makes me grateful that this is so.

Now and then, on a more than commonly balmy November day, I still go after the whiting and mackerel, but the Babbacombe ground lies too far away from Teignmouth to be reached those short afternoons with any comfort, unless you have the aid of steam power. Sometimes a friendly motor-boat, of which several are owned in the harbour, gives the "Hirondelle" a tow out and back, which is not only a saving of time, but also sparing of my boatman's labour, as it is a dreadful pull on the very calm days, on which alone fishing is much pleasure. The most enjoyable hour's fishing that I remember on that ground was with poor Aubrey Harcourt, in October, 
1900. He had asked me to go with him on a fishing cruise on the "Heloise," and I joined at Cowes, from which, after staying the night at the Squadron Castle, we got away next afternoon and had a splendid run to the West Bay, our chief amusement being the loss of box-kites, of which, easily amused with such toys, he had bought up a stock in Southampton. Daybreak next morning found us lying off Teignmouth in a dense white fog, and at high water the red-bearded pilot took us into the river, not without a word of protest from the Scotch skipper. That was the week of very low springs, and the little there was to spare under her keel that night gave me a very agreeable quarter of an hour with the Scotchman on deck next morning, before mine host was out of his cabin. Never again, he vowed with truly boreal vigour, not for all Mr. Harcourt's (qualified) guests, would he ever take yacht of his into such a (minutely described) river. As a matter of fact, not only did "Heloise" leave the river as spick and span as she entered it, but she was there again for a week, same skipper and all, two years later. On our second afternoon, Harcourt fancied a couple of hours fishing, so my boatman got some mussel bait ready, and after tiffin we fared forth in the yacht's gig, towed by the tug, which we hired for the occasion. It was a perfect autumn afternoon, with not a breath of air to stir the sea, and 
in a little over an hour's fishing the basket was a hundred and twenty-five whiting and mackerel, the latter taking the bait so greedily at the top of the water, that it was only by using a heavy lead, to get the hooks past them, that we could pick up the whiting at the lower levels. While the fun was hot, Harcourt was very amused, but he never pretended to be a fisherman, and the first lull in the biting was the signal to go back to the yacht and there fly the last of our kites. That night it came on to blow, and we went down to Plymouth ignominiously by train, leaving the yacht to follow round, and next afternoon we spied her beating round the Yealm, but it was too rough for any more fishing that trip. Two months later I spent ten days at Nuneham for the shooting, having great times in the Pinetum and Lockwood, where pheasants and wild duck fell together. I can see Harcourt before me now as he stood on the little bridge and, shooting with his father's old hammer-gun and black-powder, brought down bird after bird. Walking with the beaters, tapping lustily with sticks, and adjuring the running birds with nautical warmth, were the skipper and steward of the yacht, their professional uniform striking a strangely discordant note in the woodland scenery. The only approach to fishing on that occasion was when Alfred Shaw, also of the party, taught me how to catch a pike 
Nottingham fashion. That wonderful bowler is not so well known as a fisherman, but the accuracy with which he threw from the reel into a tiny patch of deep water among the reeds was beautiful to watch, though I found it impossible of acquisition in so short a time. Still his patience was inexhaustible, and we spent some very agreeable hours, in the intervals of shooting, I casting with great precision into the thickest of the reeds, and the two of us then punting across to disentangle my trace and line.

The interest of an occasional night's congerfishing cannot be gainsaid, and, of the two, there is far less discomfort on a warm and calm night in August than on the cold, rough seas of November. The stillness, the twinkling lights of fishing fleets, the strange sounds from unseen birds and porpoises, the thrilling sensation of fighting with a big fish in the darkness, all combine to afford an experience, which every fisherman should be able to call his own, but which soon loses its first novelty. It is therefore not without satisfaction that I have learnt the whereabouts of isolated lighthouse-rocks and other sites, where large conger may be caught in broad daylight any fine week in August. The blackness of night, to say nothing of losing your rest, is a comfortless handicap.

Sea-sickness is the worst form of discomfort, $3-(2272)$ 
with which the salt-water angler has to contend. Scrope, author of one of the most delightful books ever written on salmon-fishing, owned himself too sick to trust himself on the sea, so that his criticism of sea fishing, on grounds already alluded to, is wholly without value. Anglers with a predisposition towards the distressing malady need not therefore conclude that sea-fishing and comfort cannot be made synonymous. They can either fish from the beach or the pier, or they can, better still, choose a holiday resort with an estuary that affords fishing grounds as smooth as the Thames at Oxford. There are many rivers in England, of which the tidal reaches give in summer bass of $10 \mathrm{lbs}$. and over, and in autumn codling and whiting in numbers. Round the island of Santa Catalina, in California, the tuna, or tunny the largest fish which sportsmen seek with the rod, is taken of immense weight in water nearly as calm, while in many an Australian creek the sea-fishing is most artistic where no ripple stirs the surface, and the boat, moored fore and aft, lies as still as on a pond. Now and again, during a spell of very fine July weather, we also get the open sea as calm as this six or eight miles from land; but such conditions cannot be relied upon for long together, and those who have any fear of sickness will do well to choose an estuary, where they can be sure of calm water, no matter from 
what direction the wind blows. Next best to an estuary is a place, like Looe or Mousehole, with an island immediately opposite, for this usually affords smooth water on one side or the other.

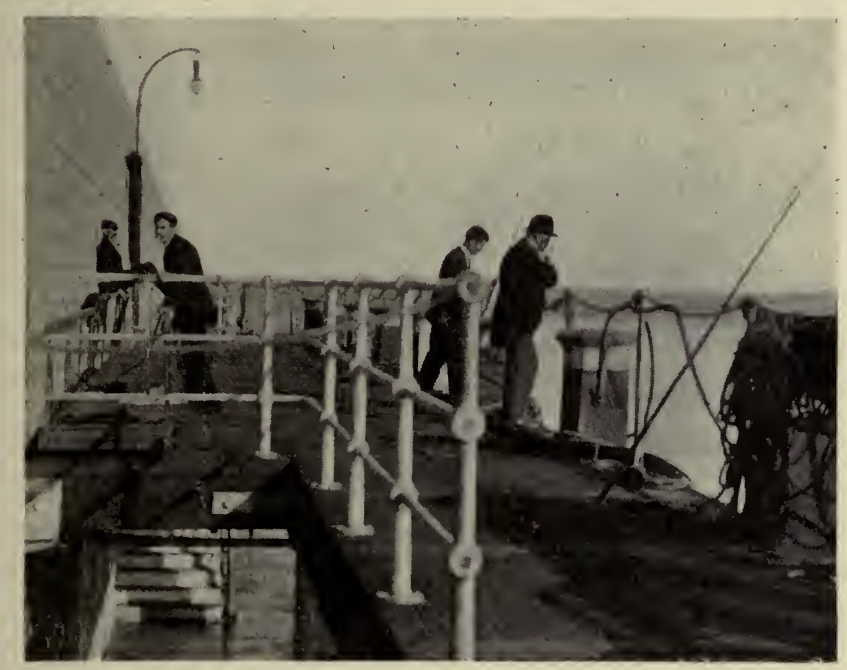

THE PIER FISHERMAN

Looe is doubly favoured, having, both estuary and island.

To night-fishing and fishing in winter time let me here add a third recantation, pier-fishing. A few piers contrive, by charging a high entrance or fishing fee, to exclude all but anglers from the stages. On the Prince of Wales' Pier, at Dover, for instance, the charge for fishing is one shilling 
a day, higher, I believe, than on any other in the Kingdom. At Folkestone Harbour, the proprietary railway company charges fourpence to anyone wishing to fish from the splendid pier that has lately been built at great cost. Such charges look high, but they are really beneficial to the angler, since they keep the crowd at a distance, and the crowd is the chief drawback of pier-fishing. Fifteen or twenty years ago I spent many happy days under various piers, often alone with the plosh of the water against the limpet-covered piles. Not even sport was essential to the charm of those hours, for there was so much to watch : the dory stalking its prey with sidelong stealth, the pollack dashing out on unsuspecting victims from its weed zareba, the crabs scuttling in a follow-me-leader race over the clusters of mussels, sometimes even a trusting guillemot or puffin diving within a stone's throw after sand-eels that sought vain shelter behind the posts. On calm days, when the light was good and the water clear, one looked down into nature's aquarium, where no restraining glass modified the natural behaviour of the inmates. Those delights have left such pleasant memories that it would need very little inducement to return to my first love, though this has been wanting in the Devon town where I have spent the last few summers, for the pier, however convenient to bathe from, is of little 
more use to the fisherman than the parade. Moreover, I returned from abroad ten years ago to find the piers no longer peaceful, but thronged with many kinds of humanity and giving for the most part the poorest of sport. Now and again, it must be admitted, one hears of better catches on piers than in boats, but these are the exception. Nevertheless, a cod weighing $18 \mathrm{lbs}$. and a lobster of $8 \mathrm{lbs}$. are a proud record for one week, and these go to the credit of Deal, while Clackton can show a bass of over $14 \mathrm{lbs}$., and the neighbouring resort of Walton boasts of a pier-skate of $10 \mathrm{lbs}$. Sometimes, too, piers yield most unexpected booty, and those who angle from such structures must expect anything from a crab to a victim of shipwreck. During the present summer, for instance, a Brighton angler, fishing on one of the piers, landed a garfish, a customer that we usually look - for with the mackerel shoals some miles from shore. Among recent records of the jetty at Yarmouth, from which sport is at times better than from the longer pier, is a diving-bird, of a species apparently unknown in the Tollhouse Museum, which took a fisherman's hook and was duly brought to the net. As another proof of the strange company found in the neighbourhood of piers I may finally mention a newt, which showed signs of having been but recently swallowed by a whiting caught off the pier at St. Leonards. A good deal of 
speculation was printed with regard to that newt, but there is no great difficulty in concluding that it was washed out to sea from either Fairlight Glen, or from the east side of Dungeness, for newts abound in the famous Warren at Folkestone, living in little ponds within a hundred yards of the shore.

I hope that the modest geographical range of the few reminiscences recalled in the following pages may not disappoint those who seem to labour under the false impression, for which I am in no way responsible, that I have fished every sea from Shoreham to Shanghai. A triangle on the Mercator map, having Christiania, Funchal and Sydney at its corners, would include all the bays that I have fished and more that I have not. Some of the fishing scenes within those limits I have endeavoured, with I know not what success, to depict less for the practical instruction of those who may visit the waters reviewed than perchance to amuse a few who lack the opportunity or inclination to go abroad. There is, for one constitutionally addicted to travel, but tied by work to England, a grain of consolation in the retrospect, which others may like to share. Those foreign memories are very sweet and very often mitigate the bitterness of thwarted plans for further foray of the kind : the "fond credulity of silly fish" in the Baltic, the romance of nights spent on the Mediterranean, 
the unaffected hospitality of brothers of the angle in Australia, the merry Basque knaves with whom I fished at Biarittz, the blaspheming Spaniards and pious Mussulmin who took me out at Tangier and Dar-el-Beida, the glories of spring weather at Madeira all have their place in my affections. Yet it may fairly be doubted whether, for all their schnapper and a score of other fishes that we know nothing of in our cold northern seas, any coast north or south of the Equator, east of Greenwich or west, can offer on the whole better sport than a little knowledge and patience will discover on the coast of Britain that faces south between Dungeness and the Land's End. Discarding for the moment the hundred bays and estuaries of the east and west sides, the unrivalled lythe-fishing among the Scottish isles, with almost virgin grounds on the west coast of Ireland, we may find in four out of the six Channel counties every kind of sea-fishing known in South Britain. The chalk foreshore of Kent, the sandy bays and shingle beaches of Sussex, and the rocky grounds of Devon and Cornwall yield the finest chance of bass and mullet, or mackerel, cod, pollack, whiting, conger, every sea-fish, great and small, that means anything to the fisherman or epicure. Here and there, over-fishing has unquestionably worked the evil on the home grounds, of which it is capable, but the fishes most favoured by the sportsman, 
the bass, the pollack and the grey mullet, are in no danger of being trawled much nearer to extinction, since that devastating engine captures them only incidentally and not of set purpose. The pollack keeps to the rocks, and the worst intruder in its stronghold is the trammel or handline: The other two thrive in sheltered estuaries and shallow creeks, equally beyond reach of the most effectual commercial methods of capture. Now and again we hear accounts of bass being driven away by dynamite, but such practices are much less rife with us than on southern shores, where indeed the indiscriminate use of bombs has ruined once productive home grounds.

No attempt has been made in the following pages to conceal failures. At most, explanation of the circumstances under which they were scored is offered for the reader to accept or reject, and not to excuse them would be more than human. One chapter, indeed, will be found to treat of little else. Part of the charm of fishing lies in its light and shade, in the success which follows on the failure, sometimes thanks to lessons learnt in time. It rarely happens that the loss of a fish is unaccountable. For the moment perhaps the angler's face wears an expression of baffled purpose attributable only to ill luck, and he may, if in company, even keep up the pleasant fiction of 
1gnorance where to lay the blame. In his heart of hearts he knows right well that he forgot to test that knot tied hurriedly at starting, or that he used yesterday's hook, of which he saw the gut was frayed when he unhooked the last fish. In other cases, he knows that no part of his tackle was at fault, but that his own manner of fishing brought about the parting of the ways. Too great a strain, or too little; too prolonged a fight, or too much a hurry to end it; too much or too little confidence in his tackle; such, according to circumstances, are the explanation. Failure in shooting does not convey the same morals. A miss is as good as a mile, and little good comes as a rule of analysing the cause. You do not, whenever you miss a bird, examine your gun or your cartridge. If you did so, your host would not unreasonably conclude that you were suffering from sunstroke. Failure to hit the birds may be a matter of temperament (as it is with a man I have shot with as long as I can remember shooting at all) or of abnormal condition. I assume that the gun fits, though you occasionally see men out with guns that fit them about as well as their wife's boots would. When a man misses bird after bird he will sometimes tell everyone that he was carousing the night before, and it is then long odds that he is a teetotaller and was abed by ten. In fishing no such excuses serve, or are indeed wanted. 
There is individuality in a fish fighting for its existence that cannot be looked for in birds, driven or otherwise; and even with both the fisherman and his tackle all that could be desired, an unusually big or cunning fish will sometimes make good its escape.

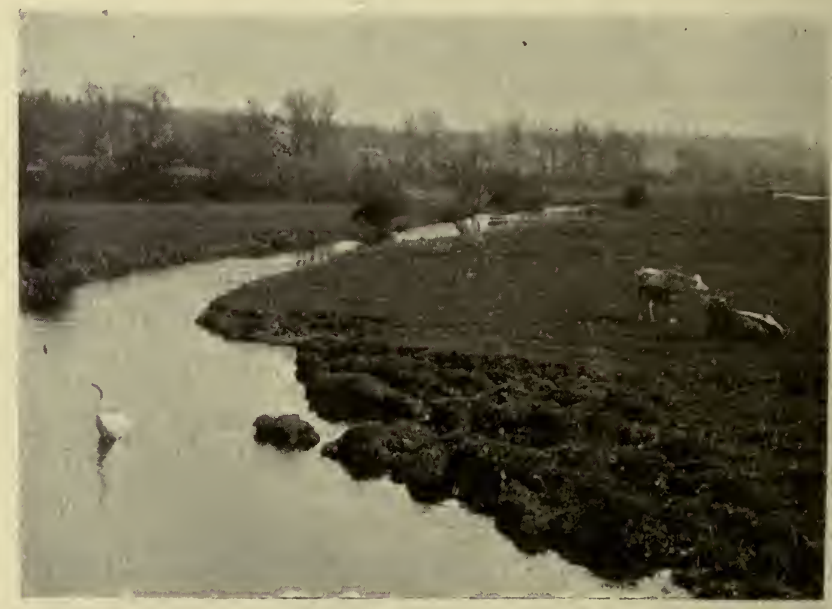

THE PEACEFUL SCENES OF RIVER FISHING

Of such few experiences of river fishing as have fallen in my way this retrospect takes no account. Indeed, I am the poorest of performers with the fly-rod, and my most recent efforts, over the broad pools of the lovely Orchy, left the salmon unmoved, while on Loch Etive, where fresh mingles with salt, and.sea-trout, brown trout, and 
lythe (i.e., pollack) may die on the same hook in successive casts, I was scarcely more fortunate. The pike of a snow-bound Norfolk Broad, the barbel at Datchet, the roach in a pond very famous for those fish, have alike voted me the most transparent of deceivers.

Forth then fares my tale, over the seas of memory; over the world's waters. It is good to get away from the present, to join hands once again with dead or absent shipmates, to feel the sting of Pacific spindrift and the grandeur of the tropical storm. It is also good to get back from the dream to the reality, from the far off seas and coral strands when

" The Coastwise Lights of England give you welcome back again!"

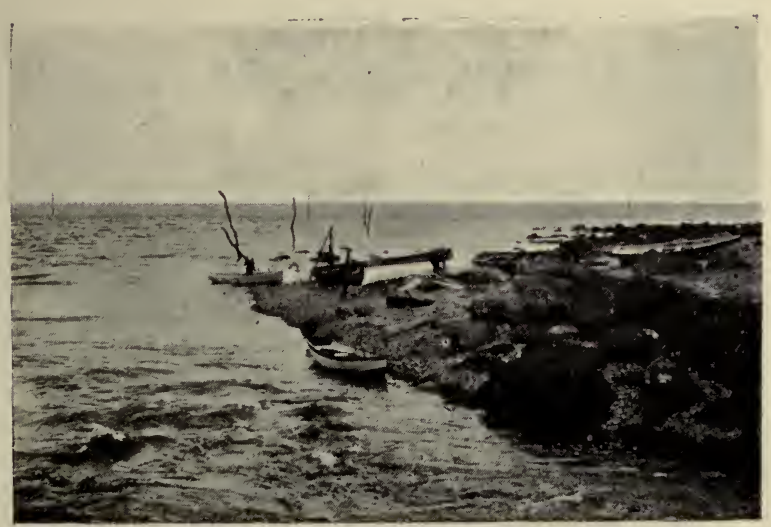



EARLY MEMORIES 



\section{II}

\section{EARLY MEMORIES}

Lowestoft in 1880 -Bournemouth Pier, 1881-Hastings in the Eighties-Pout-fishing in Sussex and Cornwall-Originality sometimes the Secret of Success-Pier Crowds-A Conger caught and a Bass Lost-Sport with a Stingray off AdelaideRambles among the Rocks-Digging Lugworms for BaitThe Unregenerate Use of "Night-hooks"-The Aboriginals of East Sussex-Small Game at Bognor-Wrasse instead of Mullet-Littlehampton-Imaginary Bass in the ArunFishing in Canals-Modern Development of Bournemouth-A Good Bag-Trouble with the Steamers-Rocks in Bournemouth Bay-Dogfish-Pollack-Kent-Ramsgate and a Failure-Deal and Its Competitions-The Admiralty Pier and Other Spots at Dover-Changes at that Port-Early History of the British Sea Anglers' Society.

In order to stretch this retrospect to that quarter of a century which is commonly accepted as the minimum range allowed to the vanity of autobiography, I must conjure up dim memories of the Lowestoft quays in the year eighteen hundred and eighty, where, close beside a drawbridge, that was usually open when one had to catch a train, we angled, unsuccessfully for the most part but with the application of zealots, for the smelts that foregathered among the piles. A fond parent misspent much of his leisure in holding firmly to 
my trousers in order that I might not be drowned in the dock. I have often thought that if in a drowsy moment he had relaxed his hold . . . . so have others; but it is too late for vain regrets. The smelts are recalled only as few and far between, also as occasioning much unpleasantness with a typical Mrs. Lirriper who did not like the job of cooking such fry ; but the rod I shall never forget. Since those unsophisticated days the same hands, grown stronger and more difficult to please, have grasped all manner of length and weight, of bamboo, greenheart, hickory, yet never again so strange an implement as we used for those Lowestoft atherines, a Japanese pattern, each joint of which packed within the next, and the whole into the butt from which it could be expelled telescope fashion by blowing down a hole. When not actually employed in its legitimate work, such a rod afforded endless variety and recreation by being discharged against the ears of friends and acquaintances, who received the salute according to their individual temperament, but when a cousin had missed the loss of one eye by about an eighth of an inch, these innocent pleasures were sternly interdicted. Sea-fishing for sport has been taken more seriously in the years that have since elapsed, but, though I have since visited Lowestoft's marine laboratory, in which Mr. Garstang sifts the evidence of North 
Sea investigations, I shall always remember the place five and-twenty years ago. Always, alas, I shall associate its quays with the merry laughter of one who fished beside me, and who later played for his school at Lord's, but whom the gods loved too well to leave with us below.

It cannot be pretended that those early fishing memories are very vivid, for my diaries date back only as far as 1885 , and the previous period has left few landmarks. There was some primitive pier-fishing at Bournemouth in the summer after the Lowestoft visit, chiefly for sand-smelts and flat-fish. Save when an affectionate relation could be persuaded to finance a day's boat, which used to mean half-a-crown an hour, an extortion mitigated more recently by the energy of the British Sea Anglers' Committee and its agents round the coast, those early memories are bound up with piers and harbours, Bournemouth, Hastings, Bognor, Littlehampton and Portsmouth among the rest. The summer of 1882 was spent far from the noisy shore, on gliding stretches of the winding Mole, near Esher, where I succeeded in catching a number of very small roach, and failed to account for a single very large pike, of which I dreamed all through my holidays. For the rest of the early eighties, in fact for the next three summers, Hastings Pier was the scene of much slaughter $4-(2272)$ 


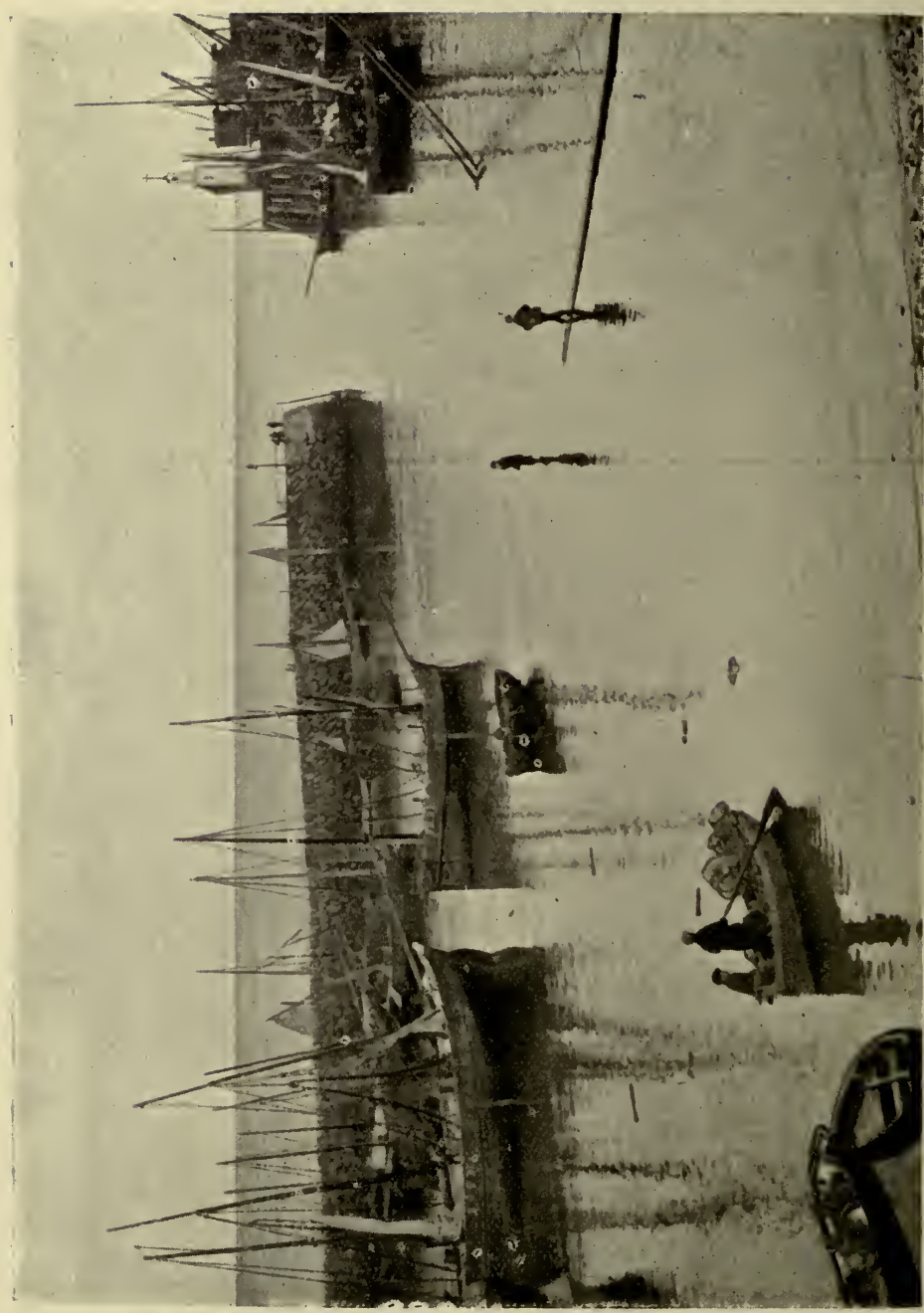

공 
of whiting-pout, a confiding fish that, to my unspoilt taste, gave capital sport on a light rod and fine gut tackle. Early and late on half a hundred August mornings I would squeeze under the turnstiles before the official hour of opening, a breach of the bye-laws with which I reconciled a not too squeamish conscience by the reflection that I held a monthly ticket. - The fishing was of the simplest and never frustrated our modest ambitions. The rod was put together on the upper deck, for fear of losing a joint through the grating down below, and the small hooks on the gut paternoster were baited with fragments of peeled boiled shrimp or raw mussel. Then a favourite position was chosen with due regard to the direction of the wind and set of the tide, and within an hour or two the wicker creel was once more too full of bronze pout for the lid to shut down. The best of these were fried for luncheon or even, when I could tear myself from the waterside in time, for breakfast, at which meal, eaten within a few minutes of their having swum to their destruction, they were much better eating than many a more pretentious fish bought several days after it is caught. As one of the rock-dwelling fish not commonly caught in the trawl, the pout is rarely seen at the fishmonger's, in spite of which it is, if perhaps less delicate food for the convalescent stomach, quite as agreeable eating as the true 
whiting and rather less insipid. On some parts of the Sussex coast, it is true, the trawlers fish over the rough ground, but even so they catch few pout. In Cornwall, on the other hand, some of the hookers anchor their small boats over favourite gulleys and catch these fish by the hundred, but

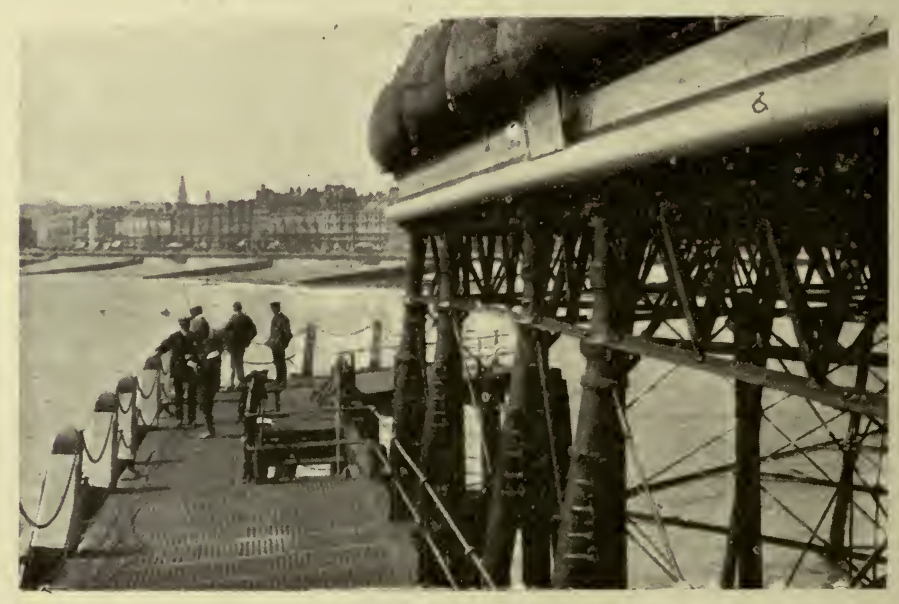

HASTINGS PIER

they fetch only a low price and are invariably bought up by the "jowders," who retail them among the farms and villages in the neighbourhood. I have caught pout in Cornwall weighing a couple of pounds, and at Folkestone I lately saw one brought ashore that must have weighed more than three, but one of half-a-pound was a monster in those days under Hastings Pier. 
The only other fishes that we lads used to catch there was an occasional lean plaice or, after a spell of east wind, a weever, evil incarnate, which was treated with either foolhardy indifference or exaggerated terror. One man I remember to this day with respect. He used, all through the August of 1884 , to catch large bass at high tide,

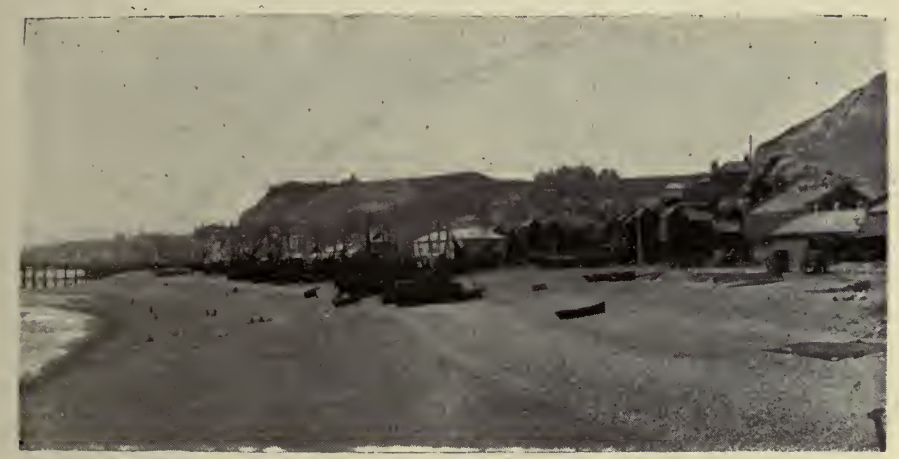

THE BEACH, HASTINGS

some of them fine fish. Baiting with squid, which he was known to procure from the trawlers that send their harvest ashore each morning opposite the fishmarket, he used a couple of handlines, always fishing inside the pier, among the piles. On calm days, morning or afternoon as the tide suited, he would take off his shoes and socks, roll up his breeches above the knee, and stand in the water at the lower end of the east stage. Whether his 
purpose was to get clear of the crowd, or to reach deeper water, we never asked, but the plan succeeded, and day after day he earned our unappreciated adoration bystalking off the pier with several good fish. I always respected not so much his success, which was due solely to the deadly bait which he alone used at the time, as his indifference to the chaff launched at his bare legs by envious rivals, or by such festive trippers as herded on the upper deck. Had these latter indeed been content with launching chaff only, all might have been well. But the August excursionist of the roughest type always was a muddy knave, and not all the solicitude of a County Council, which places Charles Lamb on the Index Expurgatorius of school prizes, can do much to mend him.

Fifteen years later I came across another case of profitable contempt of the carping crowd, this time at Littlehampton, where a crafty angler waded, without regard to the jeering of the Philistine, out into the surf and there, casting with some bait, of which he contrived to keep the secret, more than once caught a creel load of bass and other fish. In sea-fishing at any rate, though a respect for local methods is not always out of place, he often succeeds who throws tradition to the winds.

Those were happy mudlarking days at Hastings twenty years ago. Of clothing we wore no more than decency prescribed; if anything, rather less ; 
and if more bait was urgently needed before the turn of the tide, off sped one of the company to the fishmonger's in Robertson Street, without wasting the precious moments in replacing shoes and stockings that had been removed that he might fish far from the dry-footed crowd. Hastings Pier knew me and my tackle at intervals down to the year 1889, since which time I have not passed its turnstiles at any rate in angling mood. One afternoon that August, when the discoloured waves were still rolling in after a three days' gale from the south-west, I baited a throw-out line with half a bloater and flung it out in the surf. Within five minutes it stiffened out, as if it had got foul of a torpedo, and I soon had a lively conger of six or seven pounds slipping about on the gratings. So grisly a prey would not evoke raptures to-day, but it is when we are grown more fastidious in our sport that we recall with regret the unsophisticated times when that delighted which might now disgust. Anyhow, I killed the conger before an admiring crowd and stalked off the pier as proud as if I had found an okapi. (This is a shocking anachronism, for which Sir Harry Johnston will hardly forgive me, but it conveys some idea of my pride.) Nor was the conges done with, for a slice of it figured that night in a very excellent brown stew with sweet herbs, which my landlord, sometime cook in a 
mess at Gib., contrived to make out of such unpromising material.

The next day, the same line, indeed the same hook, gave me a keen disappointment, which was however, no more than I deserved. In the brutal fashion of pier-fishing of those days, I lowered the greater part of a fresh herring on the hook. made all fast, then went upstairs to buy a paper, or light a cigarette or something equally irrelevant. Thither, almost immediately, flew a breathless attendant with the intelligence that there was something pulling at my line "like the devil." There was hardly enough line out for his diagnosis of the disturbance to be taken literally, so I suspected a bass. Sure enough, a fine fellow, thirty inches or so by the looks of him, ten or twelve pounds weight by the pull, was soon brought struggling to the surface. The manner of his undoing reflected no credit on either of us, but, if he had been over greedy, he was now over-strong. Having fretted the hook against the post, a favourite trick with bass, if allowed enough slack line, he gave a final wrench and, just as the pier-master gave him a stab with the gaff that only hastened matters, he fell back with a splash that brought a sympathetic groan from the bystanders.

Memory recalls a similar wave of unappreciated sympathy amid very different scenes. Instead of a south coast pier in the strong light of an 
August morning, the scene shifts to the poop of the R.M.S. " Oceana " lying at anchor in the moonlit stillness of Largs Bay, Adelaide. Just as the dressing-bugle sounded for dinner, a line, which I had fitted up with a hook on treble wire and baited with a whole mullet from the ice-chest, was pulled out of my hand and sped away over the side, being brought up only where it was made fast to a rail. Once or twice I managed to shift the other party a few yards nearer the surface, but invariably he tired of such promotion and sank back irresistibly to the depths. The second bugle went ; the passengers went below to dinner ; the moon rose over the bay. And still I stood by the line, growing more excited every moment, for the captive showed signs of approaching exhaustion, and, as it did not behave like any shark of my acquaintance, I began to hope that it might be something eatable, which would at any rate compensate for the mess which its despatch might soon make on deck. Alas, I was still ignorant of the gifts that Australian seas hold for those who woo them with bait. What I had in fact secured as the price of my dinner was a gigantic sting-ray, for, just as the passengers trooped along the deck from the saloon companion, I brought it to the surface, gleaming white in the moonbeams, its long tail thrashing the molten silver like a flail. A crowd soon gathered about me, and that, of 
course, was the beginning of the end, though, when I come to contemplate any other sequel, it seems impossible that the captain could have viewed with equanimity his trim decks being made a shambles for such dirty prey. But the captain's courtesy was not put to so severe a test. With some difficulty, in the face of expert advice from about fifty people, the only two who really gave me any help being both dead and gone (Aubrey Harcourt and another), I steered the now dispirited ray round to the port gangway, which was down for such passengers as might return late from Adelaide, and the ship's butcher, a brawny zealot with a fearful knife, stepped down to stab the fish and, as might have been expected, and as was perhaps best for all parties concerned, severed the line in his haste. Belly upwards, with not another kick left in him, the great ray, which looked about the area of a full-sized billiard table, sank slowly out of sight, the moon showing its whereabouts to the last. Once again the disappointed fisherman was the recipient of that beautiful and inexpensive gift, sympathy. Anglers are churlish knaves and do not always appreciate it as they ought. They sometimes use opprobrious language when condoled with over a broken cast. And fishing is called the gentle craft!

But I digress. When we were not fishing from 
Hastings Pier, rambles among the rocks, which the ebb tide uncovers over a considerable area along the Sussex foreshore, gave us both bait and recreation in getting it. Mussels, limpets and crabs, both hermit-crabs and the green kind just changing its shell, were the chief contributions. The soft-backed green crab is irresistible and defenceless, and is in fact promptly swallowed by any fish that enccunters it, acting no doubt on that principle of universal brotherhood, which Prince Kropotkin has so touchingly described as permeating the animal world. Lugworms, a disgusting, though deadly, bait for almost every kind of fish, were dug in quantity by the longliners on the sandflats out near Bopeep and Bexhill, but we could procure enough for our purpose on the sands among the rocks. Our only difficulty in this quest was with the bathing-machine proprietors, who declared, not unreasonably, that our worming forays left pitfalls that would drive their clients elsewhere. The schoolboy, happy, primitive savage, finds pleasure even in digging a lugworm from its lair. Twenty years later he would sooner write out a thousand Greek lines. Still, there is a moment's interest when, having dug deep enough, you just catch a glimpse of the unsavoury recluse disappearing in his burrow, like a train entering a tunnel. You drop the spade, fall on your knees beside the shaft and, thrusting 
your arm into the wet sand up to the shoulder, grip him firmly but lightly between your fingers and draw him forth without even breaking his tail, which comes away like a lizard's if roughly handled.

Another form of "sport" among those rocks was the setting of " night-hooks," A single hook was attached by four feet of watercord to the middle of a stick of firewood. The hook was baited with a dab's head, and the stick buried a foot deep in the wet sand near low-water mark. Next tide, we were down there, waiting for the water to uncover the grounds, that we might go the round like Indian trappers, and occasionally (very occasionally) hope told a flattering tale, for, ere the tide was quite out, we could descry the struggles of some tethered captive, pulling in vain against the halter. I shame to say that on one occasion a bass of nearly $10 \mathrm{lbs}$. was taken by this barbarous method. Boys will be boys, of course, but they should be lightly caned when they develop poaching tricks of this sort.

With the exception of an uneventful outing now and then in a boat, the only other fishing that I recall at Hastings in those days was from the East Groyne. From it we used to catch both conger and freshwater eels, the latter, which breed only in the sea, having no doubt found their way westward from Rye harbour. Many doubt the 
necessity of salt water for spawning eels, yet not so many, after all, as doubted Galileo. We had to use stout handlines, and the two elements of interest in those excursions were first the continual fouling of our tackle in the rocks, from which

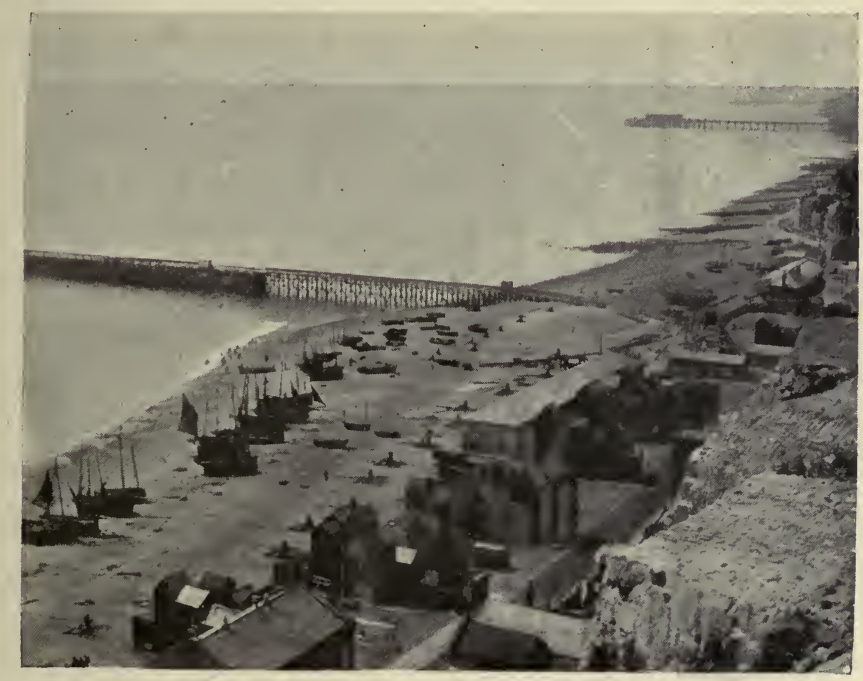

HASTINGS, FROM THE CLIFF

they were recovered by other folk at low tide, and, secondly, the adroitness with which some of the fishermen's lads aimed stones at us from seemingly inaccessible ledges on the face of the cliff. By great good luck, a belated member of this gilded youth was caught red-handed by a couple of outraged sportsmen less than a week after one of 
them had removed the bandages from a cracked face, and the straggler was, in my presence, so effectually massaged that the assault and battery ceased from that day. Must I be quite frank? Much of the charm went out of those expeditions under the new régime. Schoolboys, like women, need excitement; and what the chance of winning money at bridge is to the ladies, the chance of a broken head in a street fight is to the lads.

Very different were the conditions of the mild sport that we had from the pier at Bognor. At that resort the tide recedes so far at times that bathers have to wade a good half-mile nearer to France before they can get depth enough to swim in. The water alongside the pier is very shallow. No steamers come (or, in 1886, came) so close in, so that flat-fish gathered there in quantity, and they could be seen taking the lugworm off the hook. I used also to watch, and even imitate, the local amusement of spinning for bass from the side of the pier, the spinner being simply let down on a line and carried out by the tide. During a stay of six weeks I saw exactly one bass, a small fish, taken in this manner, by a stranger.

Bognor, if a wretched fishing station in itself, was at least a convenient centre from which to make expeditions east to Littlehampton and west to Chichester. At the former I fished according to text-book for grey mullet and, according to 
nature, caught wrasse of larger size than any others I ever caught in this country, save at the mouth of Dartmouth Harbour, where, six years later, I took some of great weight during a cruise on an uncle's steam-yacht. To Littlehampton I paid another visit eleven years later, which may as well be dismissed here, though out of its chronological order. On that occasion I stayed at that uninspiring port for six weeks, solely to catch grey mullet, and did not catch one. Day after day I was up before the sun and soon busy fishing either in my boat with Pelham, made fast to the east extension works, or out on the beacon in company with a number of gentlemen, who reside in the town and reduce mullet-fishing to a science. I reduced it to nothing beyond the capture of about two hundred undersized bass, wrasse, pipe-fish, blennies and river-eels, live stock in sufficient number and variety to start an aquarium on, but of mullet never a sign. Nor were my visits to Arundel after gigantic bass any happier in their results. On that peaceful, though hurrying, stream I sat through more than one tide with Slaughter, a propitious cognomen which events proved highly inappropriate. A lively dace was pitched on pike-tackle among the reeds, and Slaughter encouraged me with the imminent prospect of a bass about a yard long. All, he said, that was necessary was that there should still be 
salt water enough in 'that reach; and from the moment the tide turned to ebb he continually tested this by dipping his finger in the river and putting it to his lips. This, no doubt, lent a realistic touch to the proceedings, but we should have killed just as many bass in Arundel Cathedral, and from each attempt I went home ever sadder, but never wiser. At Chichester, the canal was the attraction. More power to those who hold railway stock, canals are not a great success in this country as regards their original purpose, but to anglers they are of considerable use. In the canal at Chichester we used to catch heaps of small roach and bream, and occasionally a fish of better size, while grunting eels serenaded us those warm summer evenings from their mudholes beneath the opposite bank.

Bournemouth in 1888 was vastly altered from our memories of it seven years earlier, but the pier-fishing had not improved with the rest, though the sand-smelts were as plentiful and as confiding as ever. Improved finances permitted of more boating, and, with or without my favourite henchman, Maynard, I made a few good catches, chiefly near the outlet of the sewer, beyond the pier-head. : Only twice in my life have I consciously fished near such an attraction, at Bournemouth, and on the coast of Australia. Even the latter memory lies buried under the ashes of ten 
years of contrition, and in future I shall sacrifice fish to atmosphere. But I anticipate. Maynard, a bearded mariner of Guernsey origin, has since those days found in regular service in Borough employ relief from the more precarious livelihood of owning boats for hire. Bournemouth indeed bears some resemblance to the East in the multitudes of its public servants. It takes about five men and a boy to measure the front of a shop or the distance between two lamp-posts, so that the Borough survey runs no risk of lacking efficient checking.

What the quality of the sport round that sewer may be nowadays I have no personal knowledge, though, judging from the number of boats and birds that assemble there in fine weather, it still seems as safe a draw as one of Mr. Oo's plays. I do not press the comparison. Alas, that we fishermen lack the broadmindedness of theatrical managers and grow too nice to appreciate the irresistible groundbaiting afforded by a sewer! Perchance we were better sportsmen in those fragrant days when we steeled our senses, anchored as near the fish as possible, and played the dashing mackerel and resisting plaice on the lightest of tackle. One day that August I fished with a Frenchman for several hours, and our boat came back to the pier probably rather more than $80 \mathrm{lbs}$. heavier than

$$
5-2272)
$$


it had left it in the morning. As some indication of the greedy manner in which the fish were biting that day, I may mention that my camarade lost a plaice, which carried away a yard of gut and three hooks; and then he recaught the fish, tackle and all, less than half an hour afterwards.

The only drawback of that ground (the sewer we accounted in those days of singleness of purpose a distinct gain) was that it lay in the track of steamers calling at the pier. When backing out to change the course for either Swanage or the Island, these would at times nearly swamp the anchored boats, though a little care and courtesy on the part of the captains might easily have given us a wide berth. Eight years later, one of the skippers, whose course is run, nearly upset my boat with his wash and so alarmed a lady who was fishing with me that I reported him to his owners and had him cautioned against a repetition of such buffoonery. I mind him well, a redheaded fellow; and his remarks on the occasion of his reprimand were classical.

It was not until 1897 that, in company with another enthusiast, who owned a most convenient Berthon boat, I varied this sewer-fishing with investigations of the rocky grounds off Durley Chine and further west, where we caught pout and conger and one or two good sized-dogfish, mostly of the kind called nurses, some of which 
were embarrassing neighbours in so fragile a craft. There must have been something more humorous than we at the time recognised in the picture

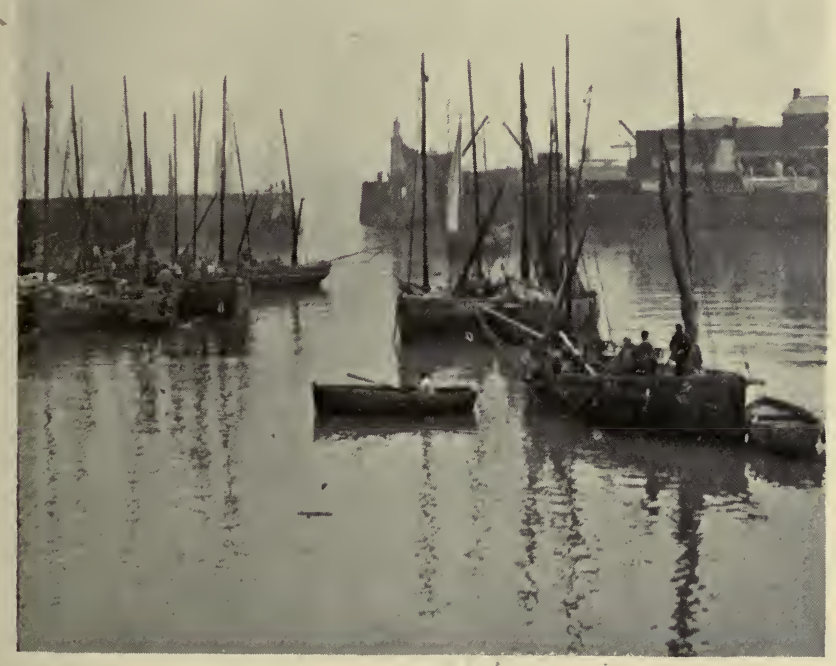

EARLY MORNING AT FOLKESTONE

of two men sitting bare-legged in an anchored Berthon, their knees drawn up under their chattering teeth and the rough back of a lusty dogfish squirming about their ankles! With pollack we never had any notable success that season, though 
three years earlier, with another friend, home on furlough from Rangoon, I caught several on the long June evenings, whiffing over the rocky ground. We used either rubber eels or salmon-flies, the latter extravagance being learnt from Alderman Newlyn, several times Mayor of the Borough and a very keen fisherman.

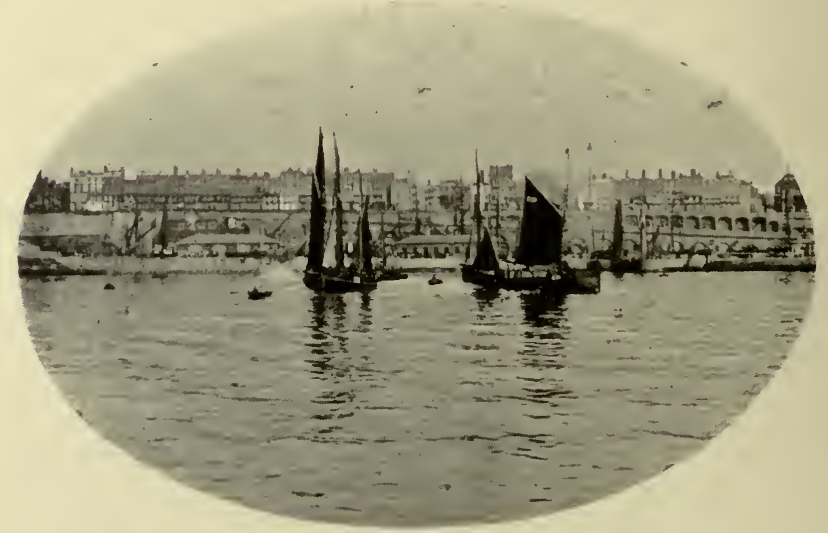

RAMSGATE AT DAYBREAK

Of late years the coast of Kent, thanks chiefly to the popularity of Deal with London anglers, has assumed great importance in the annals of the sport. Odd days of luck I have had there, as well as at Margate, Ramsgate, Dover and Folkestone, but the county has not treated me as well as some further west. My brightest memory of Ramsgate is of the last week of May, 1889, a brief 
respite after months of cramming at high pressure for the I.C.S. Open Competition, which, under the old regulations, began on the first of June. The fishing, close to a buoy outside the harbour, was successful; the examination was not. That failure rankled for fifteen years, until a distinguished Indian Civilian, my neighbour at some literary dinner or other, congratulated me on my failure on the ground that men of my complexion always "went a mucker" in the East. Whether allusion was intended to whiskey-pegs or fever, I do not remember having asked, but his assurance that ten years of India would probably have done for me was comforting, even had other consolation been wanting.

From Deal Pier I have done both summer and winter fishing, though I never, as already stated, took part in those monster competitions, which have brought a little fame and fortune to that ancient town. No useful purpose can be served by criticising, from a purely personal, and perhaps eccentric, standpoint functions which afford much harmless amusement. I simply do not like them, but the reason why; I cannot tell. I cannot, however, let the opportunity pass of criticising what has always seemed to me an extraordinary condition of the weigh-in. It is that dogfish are not allowed to count. Why not? Surely, the test of skill is not the capture of fishes that are 
best to eat; and, if it were, I fancy that dogfish have far more admirers than, for instance, pollack. It is not possible for the most skilful fisherman to prevent a dogfish seizing his bait, and when it does so it requires just as much patience and adroitness to play and kill it as any other fish of the same size. The unfairness of such a regulation is that a competitor's boat may, through no fault of either his or his boatman's, be anchored over a shoal of dogfish, and he may waste half his day playing and unhooking the vermin without getting any nearer his goal. As I have already owned to taking no personal interest in these functions, such dispassionate criticism may be regarded as gratuitous, but the condition seems to me likely to operate unequally, and on that ground alone I have ventured to take exception to it. That crabs and mussels should be excluded seems equitable, since it would be possible by leaving a large bait lying on the rocks to catch quantities of the former, and a bare hook, with no bait at all, would, skilfully manipulated, dredge pounds of the latter. But to shut out the dogfish which takes a bait in the same way as other kinds that count, seems to me an arbitrary rule calling for at any rate explanation.

At Dover I fished a good deal in the spring and summer of 1892 while staying with an old and valued friend, Surgeon-General Paske, a survivor 
of some of the hot scenes in the Mutiny and a devoted sea-fisherman. He has never deserted Dover, and has since those days caught fine bass and pollack, as well as some of the few grey mullet ever taken on a rod in the Granville Dock. Thanks to his acquaintance with the powers that were, we were allowed to fish from the Turret, then at the extremity of the Admiralty Pier, now only half way along that structure, which has grown to the dimensions of the sea-serpent. We also used to hire a boat and fish near a buoy under the shadow of Shakespeare Cliff, in days before financiers dreamt of Kent Coal, and at both places we caught numbers of pollack, codling and whiting. That lofty pier was not very convenient for fishing, though the difficulty of getting leave lent it a fictitious value, and there was of course the advantage of immunity from the crowd. It was a blessing, difficult of exaggeration, to be free of the ordinary loafer, who is always prying into baskets, always asking silly questions, his hand rarely out of your creel, his nose never out of your face. The many changes, which Government improvements and other developments have made in the harbour have not improved the sport, while the busy trawling fleet, that once fished the Varne and Ridges, is all but extinct, only a few fishing boats nowadays creeping in and out of the dock gates. Those once prolific grounds have been indeed 
almost depleted by our friendly neighbour's steamtrawlers.

More than one reference has been made to the British Sea Anglers' Society; and, as not many of the original members continue to take active part in its administration, which is nevertheless in the hands of an energetic committee that it would be hard to equal and perhaps impossible to beat, it may perhaps be of interest if I set down, as I have not seen it given elsewhere, a brief account of the circumstances that led to its inception twelve years ago. Of these I may be supposed to have some knowledge, for, little use as I have been to it during these last few busy years, it is a matter of great pride to me to remember that this prosperous society, numbering over a thousand members, had its origin in a short article which I wrote on the subject of such a society in the early days of 1892 . The article was offered to the angling editor (now the editor) of the Field and by him rejected for want of space. Sea-angling, it must be remembered, was not treated at that time with the indulgence accorded to it by editors to-day, and Mr. Senior had to be careful not to give undue prominence to a comparatively unknown sport. Later that year a little paper called Pleasure, since extinct, projected a series of articles on Pleasure Clubs, and, as a natural sequence, "Why not a Sea-Fishing Club ?" appeared with 
the rest. It was read by a very energetic journalist and fisherman, Mr. Shrubsole, then connected with another sporting paper, also defunct, but very admirable at its best-I allude to Rod and Gun, then edited by Mr. D. S. Meldrum, and owned by Mr. Watson Lyall-and he begged me to convene a meeting that might give shape to my proposals. "Fools step in where angels fear to tread," and without a moment's hesitation I acted on the suggestion. The meeting was held in a room in Swallow Street on February 3rd, 1893, and Mr. C. H. Cook, better known in the angling world as John Bickerdyke, was good enough to take the chair. Among those present was the late Gerald Geoghegan, a keen sea-fisherman and a warm supporter of the Society almost to the day of his tragic end. As a result of the meeting, a provisional committee was formed, and within a week Sir Edward Birkbeck, Bt., then in the House of Commons and closely identified with the seafishing industry, was persuaded to accept the presidency. Mr. R. B. Martin, M.P., was shortly afterwards elected Hon. Treasurer, and the secretarial duties fell to myself. In that capacity, since a labour of love always engages our best efforts, I posted within the next three months upwards of fourteen hundred autograph letters. By the end of March, the membership was sixty; a month later it had increased to one hundred and 
thirty; and in the spring of 1895, when, on my departure for the Colonies, I had to relinquish my duties to a successor, we numbered over three hundred. To-day, thanks to the untiring labours of an able committee, the Society has upwards of a thousand members and may at length be said to be doing some of the useful work, of which, with the limited material at their disposal, its first promoters could only dream.

In thus giving these few details of the founding of the B.S.A.S., as it likes to be called, I have anticipated the following chapter in point of time. Most of my fishing in the years 1890 and 1891 was done in other seas than our own.

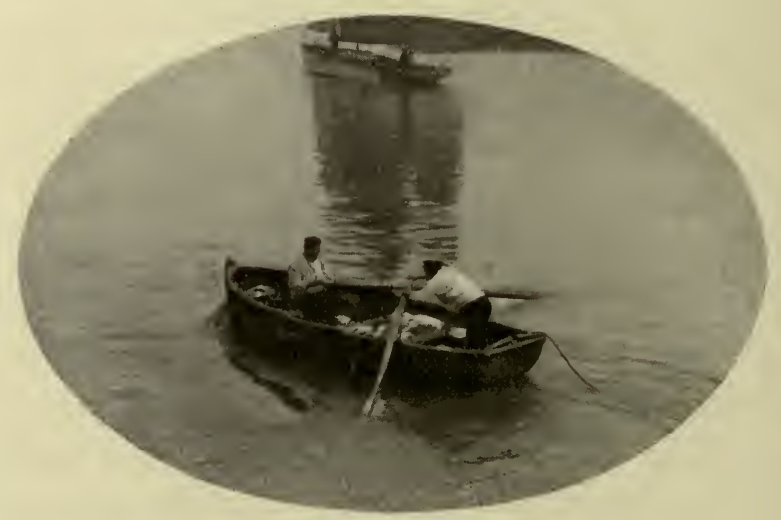




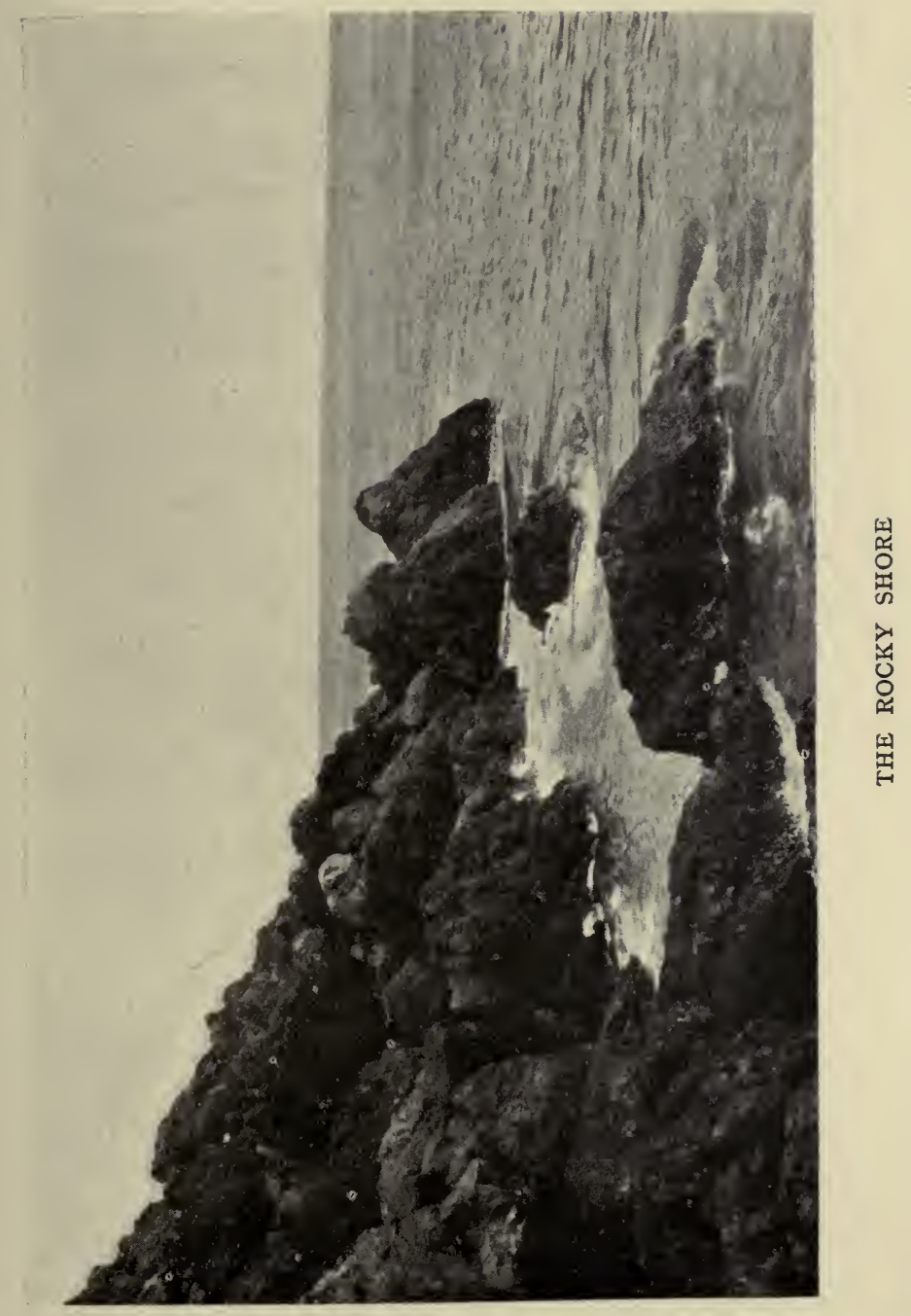





\section{BY TIDELESS SEAS}





\section{III}

\section{BY TIDELESS SEAS}

Two Memories-Warnemünde and Leghorn-A Deserted Pier-River and Sea Together-A Germail University-Rostock-The Warnow-Tyranny of Profe $\$$ sional FishermenAn Expedition after Pike-Fellow Students-The Season at a Baltic Watering Place-Easy Fishing-A Fillet of BreamA Fight with an Octopus-Grey Mullet at Last-A Night with Dynamite Bombs-A Private Mullet Stew-Mr. Sheringham's Bridge-fever-Spearing Murænas by TorchlightA Stroke of Luck at Naples.

As I idly turn the leaves of those old angling diaries of ninety and ninety-one, two widely different pictures come vividly before me. In the first, I am on a pier, not unlike that at Littlehampton, past which a river also runs swiftly to the sea. But this river flows north, and as we gaze out to sea towards the ending of the day, the sun is setting on our left, behind Denmark. The gentle swell of waves that roll between the piers rocks my painted float, yet when this goes boring under water it is to the pull of a river-bream or perch. The gutteral flow of German falls not too harshly on the accustomed ear, and each time my slender rod bends in the fray ejaculations of "Wunderbar!" "Donnerwetter noch mal!" break from those who stand around, some mere spectators, others vainly wooing with the coarsest of 
homage fish spoilt for such overtures by the fineness of my Redditch-gut. There is no envy in my neighbours, some of whom are fellow-students (alas for the studies!) at the old University round the bend of the river, and they could scarcely feel more pleasure in catching these silly fish themselves than they apparently derive from watching me.

The view dissolves, and in its place I dimly see a white breakwater faintly reminiscent of that at Plymouth. It is a night of June, not a commonsense, businesslike night of northern latitudes, but the sensuous night of Boccaccio's rose-gardens, a night on which, as that shrewd and friendly student of the Anglo-Saxon, M. d'Humières, would say, Englishmen wisely flee to sport as sanctuary from greater mischief. The imperfect darkness of the summer sea cannot veil the silhouette of anchored feluccas, while the great inner harbour of Leghorn is sparsely dotted with the side-lights of anchored steamers. These beacons of traffic are fewer than of yore, for one commercial crisis after another has brought the port of the Medici to the verge of stagnation, and by day the vast deserted quays painfully recalled Hawthorne's mournful picture of the Salem Customs House. The flickering rays of a candle-lamp at my feet rest on the queer, distorted form of a little crippled barber, my constant companion on these forays. 
In that twisted shell dwells a sporting instinct, which abhors the easy slaughter with bombs preferred by many of his compatriots. He is not favoured by nature, poor little chap. He is gobbo, and he is lame, and they say that he is also half-witted. That he is even what the aristocrat in the Mikado called, a "very imperfect ablutioner" is apparent even in this wan light. Yet as true a sportsman at heart as ever I fished with, and, for an Italian, a miracle. He never reviled his Maker when luck went against him, but shrugged his shoulders and tried again. He has just hauled a kicking parago on his fine line of black horsehair, and has affixed a wriggling shrimp to his hook for another cast into the blackness. See, now, he gathers all there is of him together for a supreme effort, and, though there is no weight to carry it, beyond that of the hook and shrimp; the line flies out over the water to its full length. $\mathrm{He}$ is under the sod, my gobbo, these five years and more, as good now as the straightest giant of them that lie up there on the hill, where the sad olive trees wave at the edge of the Mediterranean.

It was on the edge of the Baltic, in the last days of March, 1890, that I had my first taste of the havoc that fine tackle could make among fish absolutely lacking in the higher education. All my sport, save a little make-believe in Boulogne $6-(2272)$ 
Harbour five years earlier, had been at home, where the piers were so crowded with anglers eager to impart information that the listening fishes were as clever then as Rhodes Scholars are to-day. On Warnemuinde Pier, however, when, in a couple of hours I took at the first effort nearly sixty good-sized plaice and bullheads, I felt like the First Man ravishing the innocent spoils of Nature. These silly fish were as trusting as tame carp in a pond; naturally so, for, accustomed only to the rare visits of summer anglers armed with lines as thick as school pencils, they saw only the bait and had no suspicion of treachery. Some of them weighed over $2 \mathrm{lbs}$., and, as both plaice and bullheads are long-lived animals, all the best that I took back with me to Rostock, where I was nominally attending chemistry lectures at the University, leapt on the kitchen table before being turned into something more admirable than they were by Nature. Nor were the freshwater fishes of that estuary more difficult to lure than their marine neighbours. Four months later, when they had settled their domestic affairs and had come down to the sea to recuperate in the more tonic brackish water of the threshold, I had the yet stranger experience of occasionally catching sea- and river-fish in successive casts, and some of the bream and perch were almost good enough to turn a Thames fisherman in these days 
green with envy. I recollect one August, in an hour before lunch and two hours of the afternoon, catching thirty of these fish weighing $36 \mathrm{lbs}$., which would be a good account to give of three hours anywhere in England. Fishing only gave such results when the tide was running out and the river deposits thickened the water. At other times, particularly just before high water, the estuary was so clear that even my tackle rarely deceived the fish, while the lines of my German friends might just as well have been used for flying kites.

I have admitted with the callousness bred of advancing years, that often enough I ought not to have been fishing on that pier at all. I had entered myself for the "Semester" as a student of chemistry, one of the early loves that jilted me with the rest, at Rostock University. My "Matrikel" was no very complicated installation, and, so far as I can recollect, it consisted chiefly in paying my respects to the Deacon of my Faculty and my fees to the "Quœestor," after which I was duly enrolled, and circulars daily came addressed to me as Herrn Stud. Chem. . . . . . A number of lectures I honestly attended, as much for the excellent practice they afforded in accustoming the ear to technical German as for the really interesting demonstrations made by the lecturer, himself a favourite pupil of the great Bunsen. The 
botanising rambles were also fascinating, but the resulting hours with the microscope, when lovely flowers were vivisected and their fragments labelled with appalling designations that sounded like Homeric oaths, put me out of conceit with academic botany. When neither attending lectures nor fishing, I was acquiring a wide range of idiomatic German, salon and cellar alike contributing to a vocabulary that has since served me at odd times; learning how to ride bareback in a manège presided over by a rough but most efficient ex-Uhlan for instructor; or dreaming away the days in a little boat that I kept on the further side of the river, whence I would look up from some puzzling passage in the Leiden des Jungen Werthers or Wahlverwandtschaften to watch the sunbeams move along the Lutheran spires of that pious Hanseatic burgh. Now and again, the University would hold me for a week of days, or growing confidence in the saddle would lend delight to long rides over pitiless white chaussées, past farmhouse and barracks, between endless fields marked only by heaps of stones, since your Mecklenburger dreads hedges as harbouring both birds and insects hostile to agriculture. Economically perhaps he has reason on his side ; but oh, the horror of that unbroken landscape!

On the whole, however, that lair among the sighing reeds was first favourite, though on days 
when the tide suited, we would cast loose the painter and drift, on the last of the ebb, past timber-yards that had known prouder days at the zenith of the League, and sail out between the piers, perchance meeting the afternoon steamer from Gjedse, getting back to our boathouse after tea, on the return of the tide, such tide as there was. Compared with the seas that I had known, with the Channel, where it uncovered reefs of rocks at Hastings or miles of sand at Bognor, with the harbours of Folkestone and Shoreham, dry at low tide, the Baltic seemed almost deficient in that phenomenon. The "Bad Anstalt," where little swimming, but much kümmel and social intercourse, occupied the fashion all those hot summer days, stood in an almost unvarying depth of water, whereas on the English coast, it would have been alternately flooded and left sky-high above the receding seas.

Our fishing in the salt or brackish water at Warnemünde was so public during July and August that the ordinarily neglected pier became the daily resort of many lookers-on, a class of which Germany, like some other countries, gives generous measure. Such sport, however, as we stole from the upper waters of the river was strictly under the rose. All rights were apparently vested in the netsmen, who caught pike, perch and other kinds of fish in most wasteful fashion, 
yet would not, by fee or favour, let any angler so much as wet a hook. Angling therefore in the ordinary way was out of the question. Yet surely I remember, one July evening, stepping into the boat with a Swedish companion in sin, with suspiciously bulging pockets, and stepping ashore three hours later with our jackets tightly buttoned over booty that the kindly darkness hid from inquisitive eyes. Handlines, of course, had to be used, and, as the river teemed with fish in an abundance on which not even the prodigality of the netsmen could make much impression, my first and last experience of catching freshwater fish without a rod was a fruitful one.

Not only was the main river full of all manner of fish, including, so tradition had it, the mighty wels, but every fosse and ditch to which its spawnladen water had access was equally well stocked. There were pike and eels in the much netted ditch beside the road from Rostock to the sea, from which, on clear winter nights, we watched great strings of wild swans and smaller fowl sailing across the cold northern skies. The Breitling, a broad near the river's mouth, was reputed a rare haunt of large pike, and one Sunday the Götenborger and myself planned a great piking raid and invited several friends. After a too elaborate luncheon at the Hotel Beringer, we sailed out into the middle of the Broad and stuck fast on a 
sandbank. My Swedish ally had served as midshipman in his country's navy and knew a good deal about navigation. So we all got out and stood up to our waists in the cold water and shoved her off. Then we gladly set sail for the quay, recking less of the biggest pike ever spawned than of a hot schnapps and a fire at which to dry our continuations. That was not the only time the voracious pike lured me forth to my undoing. Only last winter I journeyed to Norfolk on the same errand, spent some merry evenings in the excellent company of Mr. Nicholas Everitt, whose book on Broadland is so delightfully illustrated by himself, and also sat for seven hours in driving snow on Buckenham Broad. The float went under only once, when the bait had got foul of the reeds.

With the coming of June, when we moved to some convenient rooms at Warnemünde, $A m$ Strom, the University saw even less, and the river even more, of me than before; and three or four students professed themselves willing disciples of the gentle art and deserted their academy for the seductive sport in which the stranger found such unholy joy. O excellent Bursche! The memory of your scarred faces and rotund trunks and honest, kindly hearts has stood the test of fifteen years, and will be green for many more. A little quarrelsome you were, when not maudlin, in 
your cups, a little romantic even in your sober interludes, but your genial treatment of the stranger within your gates has left a private debt that not all your Fatherland's public hostility towards her rival in the Weltpolitik can cancel. For all that your "Future lies on the Water," you were extremely bad fishermen, but as comrades I doubt if the world ever held your betters. Prosit Blume!

Like watering-places all the world over, Warnemünde threw off its hibernating lethargy with amazing despatch at the coming of the fashion. Hotels and shops were re-opened, boats refurbished, accommodation went to a premium where a fortnight earlier had been a city of the dead. Carnival, cotillon, picnic, concert followed in an unbroken whirl of gaiety. Every day the rank and beauty met at the Anstal; or in the hotel grounds. All the summer we fished on the bank, just before my door, and it would be no exaggeration to quote the average bag to my own rod at 15 lbs. a day. It was the success merely of almost invisible tackle against lines that would have hanged a horse-thief. The bait was a small lobworm dug from our garden and used with no thought of scouring. Often not half a minute elapsed from the first baiting of the hook to the moment when the red float rushed away under water and a pound perch or a bream of twice the weight bent the rod to a great curve, for, with so 
much woodwork around, it was impossible to give the captive much law. A final dip of the longhandled net settled the question, and the fish was removed to a sunken purse-net, which is the German equivalent for our creel, and which has the advantage of keeping the fish alive until the angler ceases operations for the day. Nor is it improbable, though I do not insist on such a result, that the presence of these fishes, swimming in their net so near the baited hooks, may act like decoy ducks and inspire newcomers with confidence. Looking back on those sunny summer days in Mecklenburg, I regard the fishing of the floatand-line kind, as the best I ever had and as good as I am ever likely to see again. It cannot perhaps be pretended that such easy fooling of uneducated fishes is a very high ideal for a sportsman, who should rather find his satisfaction in cheating the cunning mullet and discriminating bass. Yet it would be idle to deny that the memory of those heavy catches on the edge of the Baltic has come down through the mists of the passing years with a sweet savour that counteracts the sadder thought of imaginary mullet at Littlehampton, brill at Maldon, bass at Poole and all manner of other fish, which I utterly failed to catch in all manner of other places. Even if the unconcealed admiration of unsophisticated German friends did now and again prompt the capture of more fish than 
enough, the result was not wasted, for the average German cook does better conjuring with freshwater fish than the average English cook with the choicest marée. Epicures at a London club would shudder if offered a fillet of bream or roach, but a sliced olive and a spoonful of Moselle work miracles, and the pleasure I got out of those deluded Warnow fishes was not all in the catching,

From this, how different the sport at Leghorn! Well I remember the first day, when I went forth alone in a small boat and dropped anchor, according to my boatman's instructions, about two miles outside the Mole, baiting up a horsehair line with a paste which my barber had compounded out of fresh anchovy and arrowroot biscuits. After half an hour's interval, during which I had arrived at the conclusion that the historic interest of the Mediterranean evidently exceeded its attractions for the angler, I had a decided bite and struck, only to become aware that something extraordinary, unfishlike, was going on at the other end. A little negotiation brought to view a writhing octopus, a hideous creature that I had never before seen alive outside of an aquarium. As its arms lashed the water, visions of the struggle with the pieuvre in Hugo's wonderful romance flashed before me. But this was an insignificant looking customer, and without another thought I hauled him over the side. The next moment I 
devoutly wished that I had cut the line, thrown it overboard, made any sacrifice short of sitting in the same boat with that grisly thing, which crawled along the seat in such uncanny fashion that I retreated to the very bow. For some reason or other, a hint perhaps from my Guardian Angel, I had brought a swordstick out with me. Why one carries such weapons in foreign countries I know not. Perhaps one does not, but I was some years younger in those days, and perhaps a course of melodramatic mediæval Italian literature of the Niccolo de'Lapi order, had inflamed me. At any rate, that swordstick was one of my first purchases in the country, and the only time it served any purpose whatever was in my encounter with the octopus. Pinning the brute with the blade, I managed to beat it senseless with the sheath. This was novel, but it was also nauseating, and, as soon as the octopus was at rest, I weighed anchor and rowed back to port. The sole fruits of my outing, a polpo weighing about $6 \mathrm{lbs}$., delighted the owner of the boat, who subsequently informed me that it had tasted better than chicken. He garnished it, he said, with heads of garlic, which, to an untaught palate like mine, would only have added insult to injury.

Some of my fishing outings by day were taken in company with an American friend, and we rowed to a ruined beacon that stood alone on some 
rocks and there caught many small kinds, but nothing of account. Almost all my night fishingwas directed by my hunchback barber, and great times we had those warm June evenings, playing a pargo or sargo on fine lines and by the uncertain candle-light.

The most interesting fish to me of all that summer was the grey mullet. Man resembles the cat in his hankering after that which eludes him; a woman, a difficult stroke at billiards, or a fish is the more prized after a fight for the mastery. I had never, before 1891, caught a grey mullet weighing more than a few ounces, and the chance of enjoying sport with large fish of that species was a delightful prospect. I had been informed by the very charming Government engineer of the port, Signor Kaiser, that large grey mullet were known to frequent the private docks, and he assured me that I was at liberty to fish for them whenever I pleased. Signor Kaiser and his aged mother occupied a flat in the same house as myself, on the Scali degli Olandesi, and I recollect congratulating myself on this stroke of luck. Mullet were plentiful at Leghorn in those days, for dynamite, which had done its baleful work on many of the open grounds, had been excluded from the docks. They were even abundant in the canal that ran through the town; and opposite my study window men used to angle for them 
from the parapet with long rods innocent of joint or winch-fittings. The fish was played tight-line fashion, and was finally lifted over the man's shoulder, where it might alight on the head of a passing cabhorse. Others were caught out at Calambrone, where a man let out a bilancia net for hire, in great demand among picnic parties, who made great catches of small mullet, anchovies, pilchards and other fry, the whole being cooked and served hot in a neighbouring cottage.

In those days, and probably still, the amateur fishermen of Leghorn belonged to the working class. If their employers caught fish at all, it was generally with the aid of dynamite. I shall not soon forget the night I spent, lying awake and imagining myself the hero of one of Mr. Le Queux's wonderful romances, with two bombs on my dressing table. A Livornese acquaintance had promised to show me one of these deadly implements. I had protested against their use with more warmth than courtesy, and he, much amused by my attitude, perhaps chose an original way of avenging his order. Late one evening his valet came to my room with a small parcel, tied up in brown paper, and a note. I was spending the evening elsewhere in the building, with Kaiser and his mother in all probability, and I found both on my table when I turned in. I had forgotten all about the bombs, but the note swiftly brought 
them back to my thoughts. Frankly, I did not like such company, for I am no reformer of times out of joint, and dynamite never attracted me as a bedfellow. At first, I resolved to leave them in their parcel until the morning. Then curiosity got the better of nervousness, and, first soaking the thing in water, with some vague notion of lessening the danger of an explosion I cut the string and found two ugly looking bombs, each with a fuse embedded in the deadly paste and tightly bound round with string to prevent its falling out, so the note explained, before striking the water. At an early hour next morning I took them in my boat and dropped them unlit into the sea half a mile from the harbour. Dynamite is a heinous means of killing fish, save in such cases as that of a white man with a big camp to feed. With responsibilities of that kind, no man will trouble whether the method is sporting or not; all he asks is that he shall find food for hungry mouths.

The parapets opposite the Scali degli Olandesi afforded some good mullet at times, but the publicity of the street, with the too intimate admiration of a crown of lazzeroni, did not tempt me. Fortunately, as has already been related, I was made free of a more private stew, and the engineer begged me to fish in the docks whenever I pleased. I pleased almost every morning for the next two 
months, and by using fine float tackle and baiting with either a paste made of white cheese from Sardinia, or a kind of ragworm which could be purchased under the colonnades, I caught a few very good mullet, the first indeed to be entered in my angling records. I used to go into the yard with the gang of early workmen, for they had a way of shutting the great gates and leaving no one to open them again. This may have been an intentional check on late arrivals; at any rate, it took me regularly along the Passegiata soon after sunrise. Perfect solitude was the boon of that mullet-fishing. The sport might now and then have been brisker, but who could be discontented amid such peace, the sun sailing day after day into a cloudless sky, the saucy swifts screaming as they flew to and fro across the blue? The peaceful aloofness of those docks brought me some of the pleasure that Mr. Sheringham, in his charming book, finds in bridges. He is right, and the angler's bridge-fever is at least more innocent than that which infects some of his friends. Whether the bridge spans the river Severn or the Hythe Canal, whether the water hurries beneath his feet or lacks both goal and source, the angler's heart will surely respond to the message of those mirrored trees and grassy banks. There was nought to break the quiet of those mornings with mullet, unless perchance a passing labourer gave 
courteous greeting: Buon giorno a Lei! If a fisherman, he might stop to ask how luck was going, and endless little services were won by the gift of a cigarette or even a mugine or two. Often the creel was light; some days it went back empty; but the mere result had no bearing on the enjoyment of those lovely mornings, with a dip at the Pancaldi baths before going home to breakfast.

Perhaps my most amusing fishing experience in Italy was during a week at Naples. One afternoon I had spent a couple of hours in the cool and fascinating Aquarium, chatting with one of the professors, Sr. Salvatore Lo Bianco, and watching the feeding of the anemones and octopus. Towards sunset I strolled back to my hotel along the parade, which I think they called the Chiatamone, when I came across a ragged sportsman angling with a very long bamboo from the pavement. He looked a merry wight, so I forgot that there was only just time to dress for dinner and sat on the parapet beside him. We smoked together and were soon deep in as comfortable a conversation as is attainable between broken Tuscan and pure Neapolitan. We discussed rods, and I asked him to let me feel the weight of his, which must have been thirty feet long. With native courtesy, which one would neither look for nor find at home, he handed it to me as if it were 


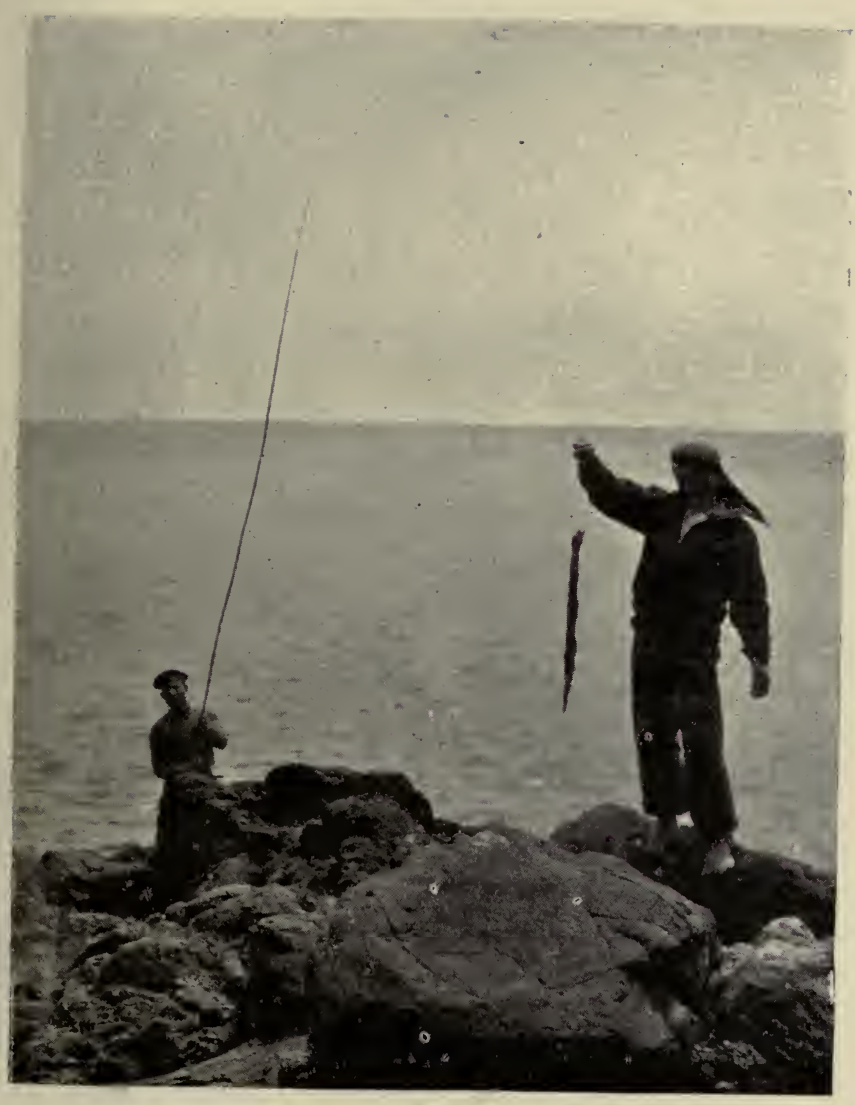

A MURENA-ON THE ROD 
mine, and no sooner was it in my hands than down went the top, and I was in a good fish, which circled in vain on the unyielding line, and I soon raised a black sea-bream of probably $2 \frac{1}{2}$ to $3 \mathrm{lbs}$. Of a certainty none of his other fish weighed more than as many ounces. He was too amazed to do more than stammer his thanks, and, as I turned away, I fancy that he crossed himself, regarding the black bream as the fruits of black magic. It certainly was a ridiculous coincidence.

The only other "fishing" that I find recorded in those journals of Italian days was the spearing of murænas by torchlight among the rocks near the Naval Academy. Sea-urchins abounded in the pools, so that, even apart from the dreadful teeth of the muræna, we were wise to go on these expeditions in stout boots. These made progress on the slippery rocks exceedingly difficult, and when anyone fell, out went his torch, and the moment a sharp shell cut his leg he made sure it was the bite of a muræna. Why we ever embarked on such grisly traffic, I cannot say, but at the time these outings were voted capital fun. Now and again we caught a muræna on the rod, but the brute gave less sport than even a conger of the same size, while the risk and trouble of taking if off the hook are out of all proportion to the amusement. As a more recent renewal of my acquaintance with this repulsive eel is narrated in a later 
page, the murænas of Leghorn need not be exhumed from the mists of time, which have in no way softened their forbidding outline.

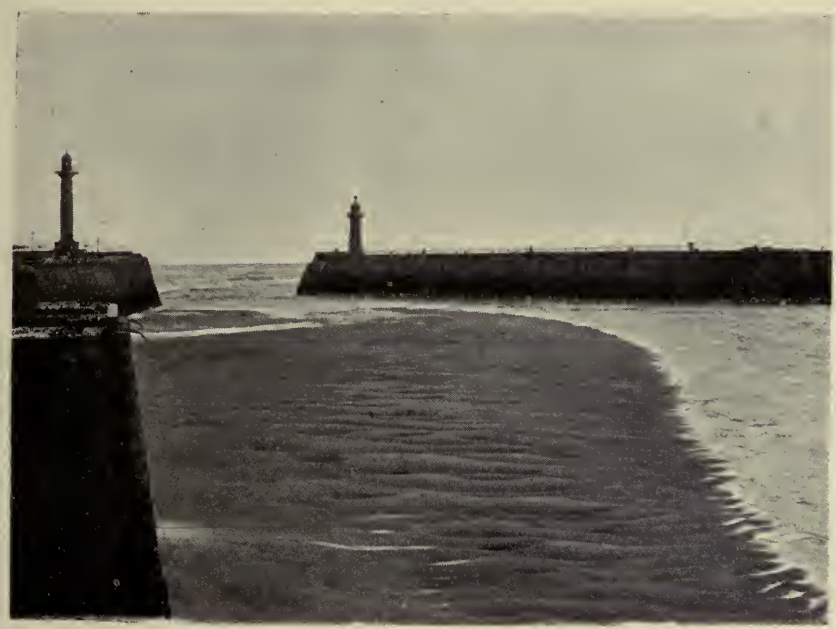






\section{POLLACK AND PILCHARDS}

The Charm of Mevagissey-The Realm of the PilchardHard Work of the Fishermen-Our Bag in 1894-A Burning Village-The Late Matthias Dunn-Other Cornish ResortsA Day's Pollack-fishing at Mevagissey-Catching a SharkA Lost Anchor and a Dead Calm-Mixed Fishing nearer Shore -Catching Squid-A Night's Congering-Harold Frederic.

TEN years ago there was not between Rye and Penzance a quainter fishing village than Mevagissey. As I first knew it in 1894, it was a little world of itself apart; but ten years have brought it new admirers, and a little of the primitive simplicity is worn off by contact with these townmice. Yet even to-day, its isolation from the railroad, with a great screen of hills intervening, and the inadequacy of the picturesque little harbour to shelter anything much larger than a mackerel-boat still cut it off by land and sea from any concerted invasion by the crowd, so that this little village, where folks are busy, either fishing or supplying the wants of those who do, remains an ideal spot, in which to rest a little while from the hisses of "the long-necked geese of the world." Coming to it that summer from the crowded scenes of Bournemouth and Richmond, I was caught in 
a spell that time has not weakened, and I have paid it a dozen visits since. I recall now my first impressions of the beautiful drive along the valley between wooded heights and beside the little torrent of turgid clay water; then the climb beside the horses as we surmounted the great hill that

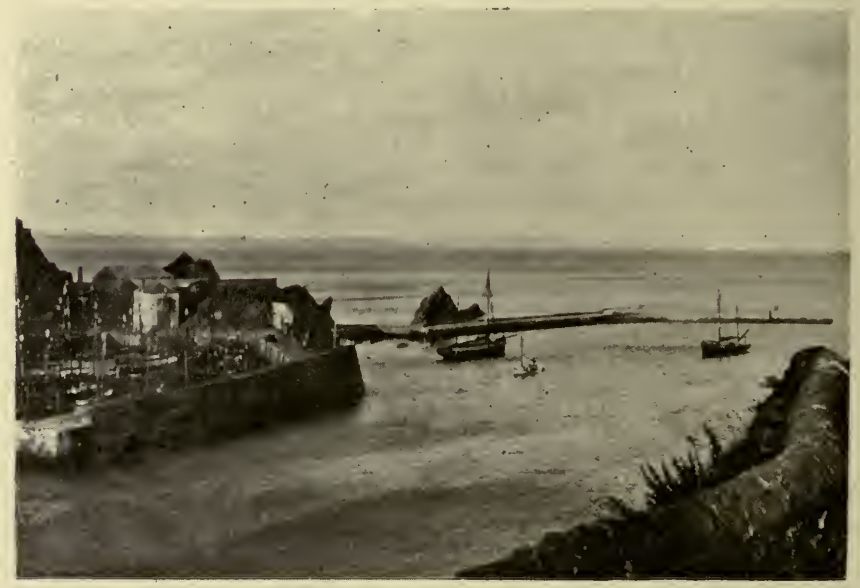

MEVAGISSEY : THE POOL

gave such sweeping views of headland after headland, even to the Rame thirty miles distant; and lastly the long descent into the peaceful village nestling between its guardian cliffs. The eye dwelt on such scenes with content, and, for the rest, the angler's nose is no caviller. The dominion of the pilchard was a little aggressive, but if 
there was monotony in the gleam of its scales and in the reek of its remains, was not the fish the cause of that beautiful fleet of red-winged craft, that, with hoarse shouting from the men and creaking of cordage from the masts, streamed out between the piers at the moment of our arrival! Our waggonette slid down the steep track on a gradient so appalling that the little churchyard, lying in a dell on our right, looked like being our next change of address. It was nearly high water that first evening, and the only eyesore in the harbour was the mass of unfinished work on the then incomplete pier. Such a scene held no place for these insignia of the contractor. Still, the pier has been a great boon, and the generosity of the laird of Carhaeys never took a more beneficent direction than in facilitating its completion. There was - there still is, and I hope there always will be-another great project under discussion at that time, the linking up of Mevagissey and the iron road by a light railway. Then indeed would the little place fall between two stools. It is wanting in the elements of success as an ordinary vulgar watering place, particularly for the children's holidays. The sandy beaches are some distance away, and the cliffs and quays are unsafe for children at play.' The medical adviser would probably pronounce against the smell from the harbour at low tide (which never yet did any harm) 
and the father of the family would vote the place too far away from his business. On the other hand, failing in its appeal to a new set of customers, it would simultaneously lose the old, since, with the advent of the railway, its great charm of aloofness would be gone.

If on that occasion I was charmed with the place, I could hardly, being predisposed in favour of all honest fishermen, fail to be satisfactorily impressed by such types as our host, John Blight, or our attendant henchman, George Marshall. John is a flaxenhaired giant, standing over six feet in his socks, and of a goodly breadth to match. For years he has gone forth night after night aboard the Foam (62 FY.), fair weather or foul, after mackerel, pilchards, or herrings, according to season. Jenathan Barron, another friend of mine, is owner of the Foam and another boat, but they all work together on a system of profit-sharing, which, if it falls hard on lean times keeps one's independence sweet year in year out. George is a man of very different type, more stocky and darker of complexion. His fishing is all single-handed hooking. Soon, no doubt, his son, one of a large covey, will lend a hand, but hitherto the father has worked his lugger alone, sailing away to the whiting ground before daybreak and returning "with a varying harvest in time for the afternoon market. 
My first visit to the place was with an ex-naval officer, since dead, whom only failing eyesight prevented from contesting the division in the Conservative interest. $\mathrm{He}$ was a marvellous fisherman with the handline, considering that on his bad days he could not see a yard in front of him, but the rod and reel he was of course unable to manage. With Marshall we fished on board the Eva, as trim a lugger as ever tacked across St. Austell bay, from the middle of July until the last day in August, and during that time we caught altogether upwards of a thousand fish, of which 309 were mackerel, 243 pollock and 206 whiting, the balance being made up of blue and porbeagle sharks, of which we caught nine, and a miscellany of rays, bream, gurnard, scad, plaice, dabs, wrasse and pout. Though we caught not a single bass, and only indeed made one half-hearted attempt on a very rough day, this was the best mixed fishing that I had taken part in. No exceptionally big fish were included in the bag. The best shark (a porbeagle) turned the scale at $30 \mathrm{lbs}$., the best conger at 24 (I killed this on the rod), and several pollack at $12 \mathrm{lbs}$.

The most memorable episode at Mevagissey that far off July was a raging fire one Friday night. Breaking out in a net loft, the flames ran like lightning along the congested buildings, their progress, favoured by a drought of -long endurance 
and by a breeze enough to fan them, yet too slight to help the fleet home. There, not a quarter of a mile from port, the maddened men watched their burning homes and strained furiously at the long sweeping oars. Not even those who believed in the efficacy of prayer dared ask for more wind, since it might whip the flames to madness and leave only smouldering ashes for them to salvage. Matters were bad enough as it was, and chapels were gutted and dwellings ruined beyond recognition during the next two hours. Mothers shrieked that their children were burning, though not so much as a face was singed. Hysterical folk, normally the most uncompromising of teetotallers, begged for stimulants. One by one the belated pilchard boats grounded in the harbour where the tide was low, and anxious fishermen, scarcely waiting to make everything fast, dashed through the mud and up the cobbled street, seeking their women and bairns and making confusion worse confounded in the quest. No loss of life; not even a damaged limb; but distracted folk so lost to calm judgment that before they came to their sober senses they had flung half their property into the Leet, a little brook that ran before our cottage and under a row of sighing elms, letting the water irremediably spoil that which the flames would have spared. Everything, from bedding to bibles, was cast into the stream, from 
which all next day women and children were engaged in removing stacks of ruined treasures. The buildings nothing could save, but so prompt is charity in even the poorest stronghold of Cornish Methodism that, with very little outside help, the subscription subsequently raised realised more than the amount required for their restoration, and on my next visit I found fresh chapels on sites where last had been heaps of débris.

It was on that first visit to "Fishygissey," as the less prosperous Gorran folk call it in derision, that I met the late Matthias Dunn, one of the most remarkable of Cornwall's many great sons. How well I remember my first sight of him : the sturdy figure leaning on a stout stick, the features unspoilt by any manner of excess, rugged with the seal of all 'weathers, showing perhaps the mark of much spiritual wrestling, for, as elder of his chapel, he would have had to unravel many knotty problems of exorcism and punishment, such as exercise folk in that primitive valley of conscientious dissent. The face was stern in repose and even hard in argument, but ever and again illumined by a smile of great charm. Beginning life quite humbly in the fishing community of his native village, working in later years in the employ of the sardine-factory, Dunn learnt his lessons straight from Nature's book, learnt to such good purpose that his information was eagerly shared 
by Couch and Day, and perhaps too by some less scrupulous to acknowledge the assistance they owed to his first-hand observation of sea life. Whether a more academic training would have made or marred the man it is not easy to say, for something depends on the point of view. On the one hand, he sometimes admitted that he felt the loss of such education when contributing to the transactions of scientific institutes, or to the more critical pages of the Contemporary Review. He was impatient to find men who had not half his facts, who had never felt Nature's throbbing pulse, so facile with the pen as to carry away their readers with the merest dole of evidence spread over their paper. On the other hand, the image of Dunn in a frock coat, lecturing to idlers and dullards from the platform, is not a pleasing one, and, if one may judge from the lack of spontaneous observation in the bulk of current biological literature, it is difficult not to conclude that he was the better for what he regarded as his defects. Any fool who has been through schools can lisp a Greek tag, but the tense grip of Nature, the birthright of one who has spent long nights out on those mystic seas in all their changing moods, is not imparted by men in gowns. His writings, shorn of " frills," were always to the point. Here and there as I look them through, they give a gleam of humour too biting to have been always appreciated 
by his neighbours. That one who stood intellectually head and shoulders above the rest should have had his enemies was only to be expected. $\mathrm{He}$ was not always perhaps as tolerant of his more ovine neighbours as he might have been; though eminently just, he may have been a hard man of business; indeed, he had to be in the interest of his employers. Yet he was much given to acts of charity when later prosperity put the luxury of almsgiving within his reach, and it is quite certain that many who cordially disliked him in life came to a juster appreciation of the man after he died. You might without difficulty have heard two opinions about him in the village ten years ago ; of his memory, you would hear but one. In his speech he never affected any but the simple dialect of the fishermen. "Master, you'm wanting to see the little turbots." Do step along now ; you'm very welcome." And we crossed the threshold of the comfortable house on Polkirt and were shown new treasures, which perchance he had gathered in his hand-net before we were out of bed that morning, for almost to the last illness he was a man of a very active habit. He would display baby turbot from the chalk water off Pentewan, a mackerel of abnormal characters, some new larval crustacean that he had discovered in the pilchards out of last night's catch. There was always some marine curiosity worth the visit, yet less worth 
it than the clever theories, the bold (sometimes even a little too bold for sober scientific discussion) speculation, the questions, even more telling than the statements. A great man I have always considered the late Matthias Dunn, not merely by contrast with his smaller fellows, but one who, in other circumstances, would have taken by right that place in scientific circles, to which he was by those who knew him ungrudgingly admitted. Three sons reign in his stead, one of whom, named after him, narrowly escaped drowning last summer under peculiarly sad circumstances, and indeed had to give two nephews to appease the cruel sea.

Many a visit have I paid to Mevagissey, the last but a few weeks ago, and the fishing is practically as good as ever. That for the fisherman is the great charm of the Duchy. The journey is a long one, I grant. Plymouth, which you may travel down to by the rural South-Western or the more coastwise Great Western route, seems the Ultima Thule of the August holiday, and indeed Plymouth offers sea-fishing of no mean order, but it is worth entrusting yourself a little longer to the G.W.R., and making your headquarters at one or other of the Cornish ports, even if you go no further than Looe and angle for bass in the mouth of the river. I know all those places, from Looe round to Padstow. Fowey has its beautiful river ; Falmouth is no less blessed ; there 
is big game on the deeper grounds at Scilly; and one of these days Padstow may, in spite of some natural disadvantages which affect industrial rather than amateur fisheries, develop as an important centre for the sport. Yet I doubt whether, from a purely sporting stand-

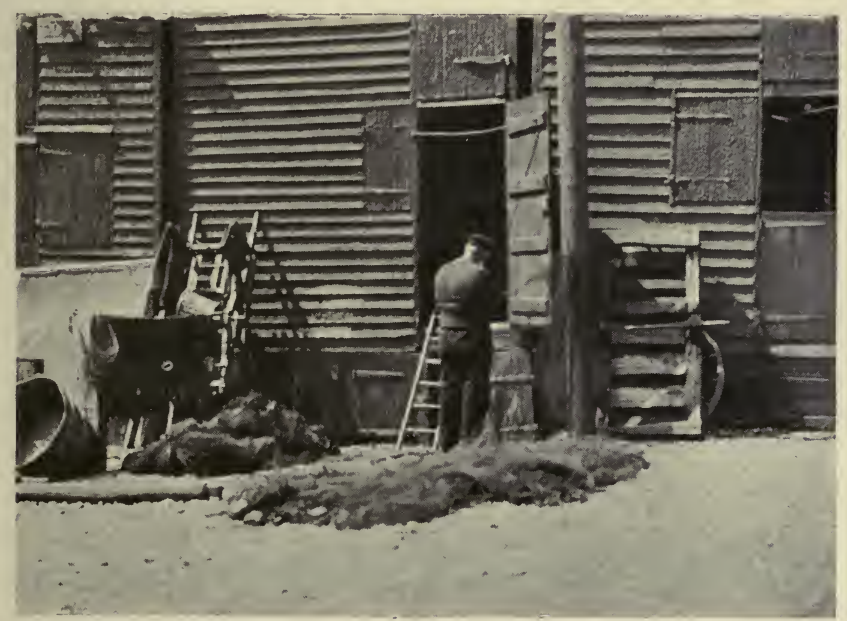

MENDING THE NETS

point, Mevagissey has a rival. For those, of course, who want bands and frocks, or rather opportunities for exhibiting frocks, it is not the place at all. Ladies can wear a sleeve that has been out of fashion these three years and not attract a sneer. Men can bask the livelong day in flannels. The only music is that of harmoniums

8- 2272 , 
and chapel choirs. Entertainments there are none. But if you want to catch fish, if you want to live among the genuine fishermen who wrestle with the deep sea for their bread, if you want to forget for a little the petty turmoil of the great world in the peaceful isolation of a little community that knows nought of tariff reform or the laws of bridge, then take your ticket for St. Austell and wire Craggs to meet you with a waggonette. The train, moving on into the far west, is the last link with modern civilisation, and he will drive you through beautiful country into a new world.

Each morning, after breakfast, and perhaps an apologetic glance at the Morning News or Mercury, according to that political bias which will not be shaken off even on a holiday, you get on board the lugger at the inner quay or outer pier, according to the depth of water at that time of the tide, and, after a little sculling to get clear of the harbour, up with the red mainsail and little mizen, and there is a fair run or dead beat, according to what ground you want to try. As soon as the little lighthouse is astern, out go the mackerel-lines, one over each side and a lighter one astern, and, with luck rather than skill, you catch one fish or a hundred. It is all a matter of running into large shoals. Now and again, a too active pollack of four or five pounds seizes one of the hooks and 
breaks away with it, for, with so much way on the boat, this fine gear has no chance of holding the heavier fish. Some of the mackerel are fine fish, though the majority are small, as the best mackerel are taken at anchor on the drift-lines. A few of them will later make useful bait for the big pollack, towards whose haunts we are steering our course ; the rest will swell George's sales this evening. It is a blazing hot August morning with a little offshore breeze, which, as the weather is set fair, we will use to help us out to Tom Ash, a distant rock, so called for a reason that has not survived in local tradition, where lie the biggest pollack caught in the neighbourhood. We shall have a long sail of it, two hours or more, for the ground lies ten miles away and is indeed nearer to Fowey than to the little port we have just left. Still, it is superb weather, and the mackerel are coming in thick enough on the plummetlines to make the time pass merrily. We shall not, it is true, get more than half an hour, or at most forty minutes of fishing, for the spring tides are very strong so far from land, and on Tom Ash it is a question of a short time and a merry, since it would require very heavy leads to keep the baits down except at slack water. Yet better forty minutes of Tom Ash than a cycle of the grounds nearer land, where the pollack run scarcely heavier than mackerel and are, weight 
for weight, not half as plucky. Indeed, on this occasion we lose a few minutes, for, instead of arriving, as we had hoped, the slack quarter of an hour before low water, we reach the ground at dead low tide (which is later out here than inshore), and by the time George has picked up the distant marks on the hazy shore, beyond Fowey and again westward of the Gwingeas, so as to bring the Eva, with plenty of rope, just over the top of the reef, the tide is just beginning to drain back eastward, so that we cannot expect even a full half hour of slack water. That should suffice us if only the big pollack are on the feed. Each hook is baited with one strip of pilchard and another of mackerel, a combination that has its object, for the oily pilchard, though the more attractive, is easily. pulled off the hook, and it is the more abiding mackerel that tempts the pollack to take a second bite and thus, with the angler now on the qui vive, meet his doom. Down go the baits and leads through the clear water. We dare not let them run by their own weight, with the check off the reel, for there are heavy customers out here, and such a piece of lazinesss might be punished with disaster. So we pull the line off the clicking barrel, a foot or so at a time. My own line, which is of wire, goes down almost sheer, for it takes a strong tide to move a wire line out of the perpendicular, and mechanically, my thoughts elsewhere, I pull 
the little coils off the reel, when, hey presto ! off flies the line in yards, down bores the pollacksteady! At low tide there are many fathoms less water here, and this plunger must not be allowed to fray the line among the sharp rocks. A strain is therefore put on the stout rod, the headlong rush is stayed, and the broad barrel of the winch is even forced a few turns in the opposite direction. But such a fish is too strong to lose heart so easily, and away it flies again, running out if anything more line than at the first dash for freedom. And now the reel on the other rod is singing a good second ; and George, too, is holding on to a tanned line, that strains up forward over the gunwale. We are among the pollack with a vengeance, and must make hay while the sun shines. George has the pull over us, of course, since he fishes for fish, not for sport ; and without a pause he hauls an eight-pounder to the surface, and, crooking his forearm round its gleaming sides, lifts it into the boat and leaves it on the hook. Then he runs to my assistance with the short-handled gaff, for my own fish is so near that I can see its dark back looming three or four fathoms down. A last rush, however, inspired perhaps by the dazzle of sunlight, takes it once more out of sight, and George has even time, before I am ready for his good offices, to gaff another of six or eight pounds on the other rod. Then at length my own is brought 
to the gaff, and when I contemplate the thirteen pounds of him lying across the bottom of the boat, the result seems worth the tiring fight. The fun is furious while it lasts. The other rod, handled by a man who never caught a pollack before in his life, accounts for a fifteen-pounder by the skin of its teeth, for, as the gaff goes in, the hook comes out, and George, in no mind to see a florin sink out of reach, nearly falls overboard in his eagerness to secure the prize. Fourteen pollack, aggregating probably $130 \mathrm{lbs}$., nearly fill the well, and then comes a lull, interrupted only by a terrific pull on my line, which I next reel in, minus the trace. Experience of such tricks has long since taught us that only a shark can be responsible and, quick as thought, George has a whole pilchard on an unleaded line, which he has flung its whole length over the stern. We keep the other hooks in and wait on circumstances. Within ten minutes the shark-line shows unmistakeable signs of having done its work, and, with sundry expletives, so mumbled in his beard that we may surely let them pass for ancient Cornish, George hauls a great blue shark, twenty or thirty pounds by the look of him, up to the bow and there makes him fast in a running noose over the tail. Not for money would we have that writhing azure pirate in the boat, for the smell of a shark's blood on a hot August day is not to be confused with that of the spice 
that the Queen of Sheba gave to Solomon, nor is its stench to be got out of the planks without much scrubbing and the healing of time. The disturbance made by the shark and the increasing strength of the tide conspire to put an end to our fishing, though it is one thing to be willing to move and another to be able. First of all, the anchor refuses to budge from the rocky purchase which George so successfully found for it before we started to fish. For about twenty minutes he pits his strength and skill against his country, tugging at the rope till the veins stand out on his streaming forehead; throwing out slack coils and suddenly putting on a strain; hoping to cheat where he could not straightforwardly prevail, but all to no purpose. We row and even sail around the unrelenting rock, and when at length the promise of compensation induces him to give up the struggle, he will not abandon his anchor without having first made fast a bundle of corks to the rope in case we should come out again at low tide and be better able to recover it. That, however, was not to be for another year. For we now realise that the wind, never very strong, has completely died away and that the bosom of the sea is as glass, a beautiful mirror for the wheeling gulls and plunging gannets, but very little appreciated by those who have to row a ponderous lugger over ten miles of its surface. So still is the air that we can even 
hear the pulsing screws of a couple of destroyers, fully twenty miles away, on a trial between Plymouth and Polperro. To anyone buried in a London club, it may not sound a very terrible ordeal to be becalmed ten miles from port on a summer sea, but it is astonishing how one resents a contretemps of the kind under compulsion. There is nothing for it but to lend a hand with the long sweepers and whistle for the wind. George, in the laudable desire to cheer our spirits, still further depresses us with an endless dirge relating the Titanic loves of the Cornish giants, who seem to have had a terrible way with the ladies. At last his quick eye catches the thin black line on the water, away to the south, and the little puff catches the ready sails after we have worked like galleyslaves for the best part of an hour. By that time, unaccustomed to such labour with oars that bulk like telegraph poles, we are reduced to pulp, and while George crowds on all the sail he can, we make a frantic raid on such of the bottles as yet contain refreshment. Happily the breeze has come to stay, and we are soon racing in past the Gwingeas and Chapel Point, though the wind has gone round to the S.W. and we make a lot of lee way, fetching nearly to Black-Head. One tack, however, just runs us between the piers and, since it is three parts high water, right to the inner steps. Thus ends our last visit for the year to Tom Ash, 


\section{POLLACK AND PILCHARDS}

for our resentment at such shabby treatment by the wind needs the cooling of another winter. Next summer, no doubt, remembering only the fights with the big pollack and the pleasure of euchring the shark, and forgetting the demoral-

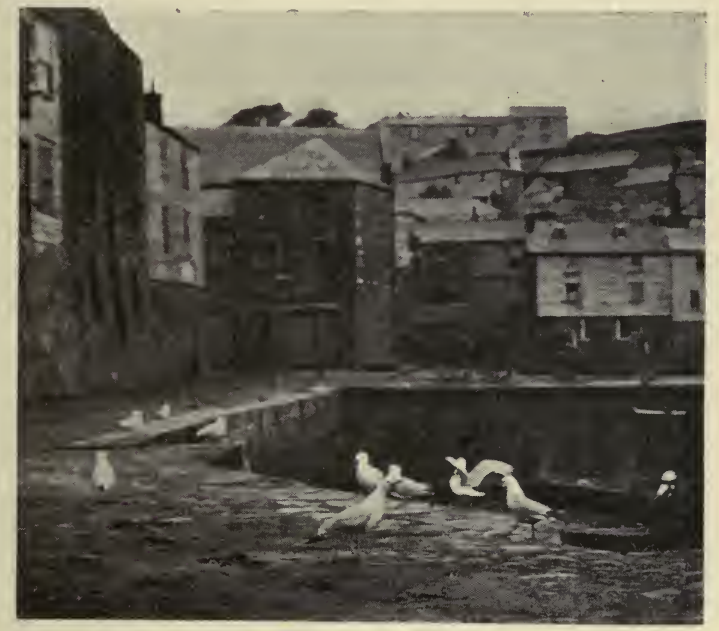

MEVAGISSEY QUAY

ising pull home, we shall be for Tom Ash once more the first fine day.

Not always is it fine enough to risk so distant a ground, and on uncertain days, or when the wind is wrong, we content ourselves with a "highest possible" of six or eight pounds on the nearer goals of Moldeser or Martin Vane. Some days, either for a change of sport, or perhaps with the 
object of giving George, who has a nestful of beaks to fill, a chance with the more marketable fish, we go for the silver whiting on the edge of the lastnamed ground. So precisely has he learnt the marks on shore that by regulating the length of cable between us and the anchor, he can put us, when at Martin Vane, on pollack or whiting as we wish. The worst of these shallower grounds is the trouble we have some days with the chad. The chad is a small red bream, giving excellent sport in the adult stage, or even when of intermediate size, when it is known as a ballard, but in extreme youth as exasperating as schoolboys in their play hour. I remember one day, on a ground known as Australia (why, nobody either knows or cares), the chad were so unremitting in their attention to our hooks, that we simply beat an ignominous retreat. The little vermin could not have driven us away more effectually had they been the largest of sharks! Now and then we were able to turn the enemy to account, for a slab of chad makes a good bait for pollack when these are really hungry, and it has the advantage of being about the toughest bait of all those in general use. There was another small and insidious, though rarer, spoilsport on those grounds. Of a sudden, your rod top would begin to twitch, and no amount of striking, and no small hook, would catch the intruder. One day the mystery was solved, for 
George lowered over the side a dreadful implement made out of three hooks lashed in a triangle, like that in use by pike-fishermen; but with the barbs filed off. This fearful engine he jerked about among the rocks until at length a look of satisfaction spread slowly over his face, and he brought up a wicked looking squid, vainly lashing the water and discharging what remained of his ink. As it is absolutely hopeless to go on fishing when squid are on the path, we took in our lines and left George to catch three or four more, which we resolved to turn to account that night on the conger-ground.

The conger roams at night all over the rocky bay, indeed there must be a seething progress of congers right around the coast of Cornwall as soon as the sun goes down behind the Land's End. About six in the evening, a couple of hours after the departure of the pilchard fleet, we leave the harbour and sail eastward. Soon we see the pilchard boats drifting towards us from just beyond the Gribbin, having in fact shot their nets off Fowey. The breeze is too light to put out the mackerel lines, so we resolve to depend entirely on squid bait until at any rate we can perhaps pick up a pilchard or two from one of the boats when the nets are hauled later on. We anchor in beautifully smooth water off Charlestown just as the church clock strikes seven. We are not 
more than half a mile from land and in more than six fathoms of water. It grows dusk, for the August evenings are drawing in painfully, and George lights a couple of lanterns and brings out the squid, no longer the inky flabby stuff it looked this morning, but, thanks to much washing and hammering and other special treatment, firm, white, and glistening like china. Each of us has a stout line, carrying two hooks and a heavy lead. We might, it is true, have brought rods for such shallow water, but I have not yet recovered from the memory of an unmanageable conger of twentyfour pounds, which I had caught on the rod on this very ground four years earlier. Exhilarating though the experience may have been, I registered a vow to use handlines for conger on future occasions, at any rate when fishing in the dark, which immeasurably handicaps the angler and favours the escape of the fish. On that particular occasion, the conger all but broke the rod, practically strained the reel beyond recovery, and broke one of my thumb-nails by a sudden downward rush that jammed it between the rod and the gunwale of the boat. This was already excitement enough for the money, but more was to follow, for, having been coaxed on deck with three or four inches of gaff in its belly, its first act of sweet surrender was with a flick of its tail to kick over our only lamp, which George had 
carelessly left on the seat. Great business ensued, which, however, would have been more appropriate in one of those rollicking old farces at the Vaudeville of other days. For about ten minutes the conger was slipping about the bottom of the boat in unrestrained enjoyment of life. Meanwhile George and I were not idle, for he belaboured my shins with the handle of the gaff, and I hit him once on the elbow and twice in the stomach with a bludgeon specially designed for pacifying conger. The last was a very palpable hit and fortunately roused George to great deeds, for his next blow, planted with chance accuracy, laid the conger out. We were then able to light the lamp and give the conger that attention which its recent conduct demanded. As I rubbed my smarting ankles, it was borne home to me that rod-fishing for conger in the dark is a pastime for either knights in armour or fools.

To-night, therefore, we are using lines. The hooks being baited with a slab of squid, and a tempting little tentacle being stuck on the point of each, we noiselessly drop the leads over either side, let them run quietly out till they bump the rocks, then pull in about a fathom of line. This has the desired effect of letting the baited hooks lie motionless, with just enough slack to leave them unmoved by the slight up and down motion of the boat. Each 
grips the line between his thumb and finger, without disturbing the bait, and waits for the first signal. In a few minutes there is a little nibble, that might be caused by no more than a stickleback. This gives place to a couple of determined pulls, and then the fisherman responds and feels the weight of a very proper adversary. By midnight we have caught fourteen eels, the largest weighing about $15 \mathrm{lbs}$., and all the while the pilchard-drivers have been passing half a mile (a little more or less, since they move in tiers) to seaward of us. And now our bait is running out, and as one of the last of the fleet is (as we can tell from the hoarse cries of the sea-birds round his sides) hauling his nets within a few hundred yards of us, we pull up the anchor and George rows alongside for half a dozen pilchards straight, from the strangling meshes. Back to our ground we go, or as near as we can hit it off with no kindly assistance from landmarks, but something is at fault, for during the next hour we catch only four more, all small males of two or three pounds each. More than once a tell-tale yawn has sounded out of the darkness, and, as nothing is more catching than this admission of a yearning for bed, we respond on each occasion. From George comes a yawn more terrific than the rest, so we give the order for home, and up comes the anchor for the last time and back we sail to the little light on 
the harbour with our slimy spoils at our feet. Half the pilchard boats are already snug at their moorings; two of them sail in abreast of us, so that we have merry company up the dark alley that leads to our lodgings.

I have elsewhere confessed that night-fishing no longer attracts me. Here and there, as on the Mole at Leghorn, or on the mackerel-grounds at Funchal, it is no doubt a case of angling at night or not at all, for the water in those latitudes is so clear, and the sun so bright, that it would be impossible to deceive the fish by day on tackle stout enough to hold them. In the muddy water of the English Channel, however, at any rate east of Plymouth Sound, between which and the threshold of the western ocean it clears sensibly, the difficulty is less to prevent the fishes seeing the tackle than indeed to help them see the bait, which must in some places hang as fruitlessly as would even Mr. Chamberlain's loaf before the nose of a starving Londoner in the thick of a November fog. Moreover, the nights of those southern countries are often much more agreeable than the days, for the full glare of the sun is at times unbearable on the water. Nightfishing therefore assumes virtues in such seas that it can lay no claim to on the coast of Britain, where there is no need to seek its friendly concealment. Anyone on a holiday can find 
enjoyment, even beyond the mere catching of fish, with the fair summer sea around, with the play of sea-fowl and porpoises, with the occasional passing of a picturesque sailing ship or more business-like torpedo-boat; but he must be an eccentric sportsman indeed who, after some experience of the sensation, can find much satisfaction in staring through the cold darkness of an English night at the glow of his boatman's pipe and hauling an occasional eel for his pains.

Drift-line fishing for mackerel has been referred to in passing as the method by which the largest fish of that species are caught. My best experience of drift-lines was on a Saturday morning in 1894. It was a pity that it was a Saturday, for that meant no afternoon market for George to sell his fish at, so that Nature's bounty was wasted on us. We anchored on Martin Vane in a glassy smooth sea, and the great mackerel were darting to and fro beneath the boat literally in hundreds. The water was so still and clear that we could watch each fish take the bait and even pull it away from a small aspirant, so as to give a better fish the option. We caught about a hundred and then left off, simply tired of the sport and conscious of the fact that the fish would fetch no price worth speaking of the same day and would be absolutely putrid by the Monday. These large mackerel give pretty sport on fine gut tackle, but 
there are limits to one's greed under circumstances such as those just described. Part of our success was, no doubt due to having the ground to ourselves. As it was Saturday, none of the regular fishermen were out, but might be found loafing round the harbour or sitting on the old benches talking parish pump politics with the gaffers.

It will not have escaped notice that the bass has so far received but scant notice in these accounts of Mevagissey. The fact is Mevagissey is not a first rate station for that particular fish. Looe, Falmouth, and Padstow all offer better chances, though much of their other fishing is vastly inferior. Still, an occasional big bass may be caught by those who care to devote much time to little result. Just west of the port is a long, low promontory known as Chapel Point. On the rocks which uncover at low water just at the end of the Point, I once flushed a covey of partridges, which had in all probability run before me as I walked slowly down the fields to the edge of the sea and were reluctant to take wing until the last possible moment, though as it was only the third week in August, they ought scarcely to have remembered the dread gun. So unusual a spot for partridges, twenty or thirty yards below spring low water mark, suggested a query whether, holding a game license a fortnight later, I should $9-2272$ ) 
have been legally entitled to shoot the birds when at length they flew round over the water. Etiquette would demand that I should not, and in any case the law would probably have interested itself in me at an earlier stage for walking through private fields with a gun under my arm. But I might equally have flushed the partridges in a boat after someone else had walked them up. Should I have been within the law if I had shot them over the water? If I remember right, I propounded the query in the Field at the time, but I have no record of the answer.

For the moment, however, Chapel Point is recalled, not as a feeding-ground for partridges, but as the shelter from the force of the SouthWest gales, under cover of which it is often possible to enjoy a day's fishing when the sea is hopelessly rough outside. There are small pollack and fair-sized mackerel off Porth Mellyn, but it is better to spend such an off day in an attempt to catch one of the big bass, for which the sands at the edge of the rocks are a rare rendezvous after breezy weather, for at such times the shore is strewn with offal washed round from the harbour. Several such endeavours I remember as having been quite futile, but on one occasion at any rate, and indeed on three, we went out to good purpose. The Eva was moored fore and aft in shallow water, parallel with the rocky shore. 
A whole pilchard, not too fresh, since the bass likes, when raiding the shore commissariat, to scent its food from a distance; is tied on the hook in a peculiar manner. As George has paid particular attention to the strength of flavour recommended above, the interesting process of baiting is left to him, as I have promised to dine out this evening and should not easily get such flavour off my hands. So George baits the hook, and, standing on the thwart, swings the line well out on the sand, so that the bait lies at the edge of the rocks. There it is given two or three minutes to settle, and then, without further disturbing it, I gently wind in the slack. That accomplished, and George having squeezed two or three more pilchards, similarly circumstanced to the first, and flung them out around my line, we both light tobacco and talk over old times. The conversation is abruptly checked by a muffled exclamation from George, who points to the rod as if he saw a ghost. True enough, there is the slightest perceptible twitching of the top ring, and a couple of slack coils, which I left purposely on the seat beside the reel, are narrowing, as the line creeps out through the rings. The rod is a stiff one, about sixteen feet long, one that I had originally built by Messrs. Watson and Hancock, of Holborn, and well adapted to this work, though designed by me for angling from the high Admiralty 
Pier at Dover, from parts of which we often experienced difficulty with the shorter rods in clearing the projecting buttresses. My hands tightly grasp the butt; the check is on the winch; and as soon as all the slack line is out, I sweep the rod back over the shoulder, and the maddened bass, with the hook driven well home in his throat, goaded by the unlooked for sting in that seemingly harmless offal, races off as if nothing would stop him short of the French coast. Yet the increasing drag of fifty, sixty, seventy yards of wet line gives him pause in his headlong career, and I manage to get his head round, and even to get ten or fifteen yards of line back on the reel. This seems to have given him new inspiration; for he tries a trick that I have had played on me by both sharks and garfish, but rarely indeed by bass, He swims with all his might towards the boat, slackening the line faster than even the five-inch reel can get it home, then, of a sudden, away he dashes at right angles, in under the cliff. If he only knew it, the odds must be seven to three in his favour, for there are rocky knives at hand, against the edge of which the line would cut like gossamer thread. His spirits seem to have recovered, for he is now careering among the rocks on the swirl of the rising tide, and any moment may, as I am fully aware, bring the closure. Here evidently is no ordinary bass tasting steel for the first time, 
but a veteran who can count his chances and make the most of them. This I quickly realise, and also determine that if the line is to break, I may as well do the trick as look on. Finesse must be thrown to the winds. Here is meat for a straightforward match of muscle, so I put on all the strain I dare, and more indeed than less extreme case would warrant, and by a sheer forcing game the great head is pulled once more towards the boat, and half the battle is thereby won and lost, for a good fish with his shoulder to the line is worth two of another with his face to the foe: The broad tail lashes the shallow water; now, and now again, the reel comes to a standstill between two equal and opposing forces, but my position, a few feet above the level of the water, gives just the advantage without which I believe the bass would have won home, and, after a stand up fight: that must have lasted nearly half an hour from first to last, with one of the combatants exhausted, and the other not wanting any more exercise for the moment, George slips the gaff into the flank of an eight pound bass of great beauty, whose scouring in the recent gale has burnished it to a dazzling sheen.

Another bass-ground lies just round Chapel Point, beside the Gwingeas, a rock which stands out of the water like a lion couchant of Herald's College. We never in all our experience killed 
one there, but one afternoon George and I hooked what he graphically, and with evidently more regard to size than the quality more definitely indicated, described as a "snorter." In this fishing also, though in more open water, the boat is moored at either end, broadside to the rock, and the time for fishing is on the first of the ebb, when you can moor a hundred yards east of the rock and let the bait drift into the shadow of it. The bait is not in this case flung out, but is dropped gently over the side, and the tide does the rest. On the afternoon in question we were fishing not indeed for bass at all, but for the large drift-line mackerel, for which, on its day, the Gwingeas ground is as good as any in the bay. We must have caught some weighing over two pounds, using the fine tackle necessary for such work, with three or four feet of single gut. In a drifting boat, where you can follow the fish, there would, or should, be no difficulty in killing the heaviest bass on such tackle, but with the anchor down it is a very different matter. Therefore, when one of my mackerel-lines went flying over the side, the wooden winder jumped about in the boat as it unwound dangerously near the end of the line, we knew from the beginning that the game was up. We did what we could. I let the line go through my fingers as gingerly as possible, and, as George was putting forth all his strength in a 
heroic effort to get the second anchor in, I actually so far tired the bass as to bring that scaly truant to rest and even coax a little line in over the gunwale. Yet it was to no purpose, and it went off with a final rush which caught me hanging out of the boat with the winder extended at arm's length. For all I know, he may still be cruising about those seas with eight and-forty-yards of line trailing from his powerful jaws, though more probably the poor devil got tethered to some sunken anchor or clump of seaweed and there died a slow death from starvation, to be finally devoured by crabs who would murmur at the poor condition of the fare. That is always the sportsman's regret when a heavy fish breaks away with hook and line, for he cannot help thinking of the torture to which, unless by rare good luck the hook comes out, the fugitive must inevitably be exposed. For this reason, I always deprecate the use of very fine tackle from high bridges and piers where more fishes are dropped off in mid air than brought to the creel. At Poole, for instance, those who fish for bass from the Hamworthy Bridge, insist on using fine gut tackle. As most of this fishing is done in the dark, the escape of the fish is still further favoured, and about nine out of ten (sometimes a slightly higher average) get away, often with broken tackle in their jaws. This is sheer cruelty. If you must fish for such heavy game 
from a parapet, it is, paradox though this may seem, far more humane and sportsmanlike to give the fish, once hooked, little chance of escape and to catch it on a line that would hold the week's washing.

With one more recollection, a sad one, I must take leave of Mevagissey. Just as that first visit in 1894 is associated with memories of Matthias Dunn, so that of 1897 brings back a still more remarkable personality. 'A year earlier I had met Harold Frederic at the National Liberal Club, at a time when we were both contributing to the Saturday Review. It may indeed have been in Frank Harris's room upstairs that I first met him, but my first memory is of a spring afternoon at the club in Northumberland Avenue, where, after lunching with him, I was telling him of the Cornish fishermen. Frederic was always a student of such small industrial communities, and, rather diffidently, I suggested that he should pay me a visit when I went down in August. To my great delight, he accepted. The fishermen in due course interested him much; the fishing little. He was the slave of his newspaper work, and often, when ten miles from land, suddenly made notes from a telegram which had to be sent to his paper in New York. He was a keen, but not a good, fisherman; obstinate, unadaptable, loth to graft local methods on his own 
ways. While we were hauling two or three mackerel a minute on our leaded lines, he preferred to dangle a futile spinning bait on his light troutrod out of a boat sailing four or five miles an hour ! That was poor Frederic all over. He would teach the mackerel to take the bait the way they ought and not give way to their silly prejudice in favour of coarser gear. When at last, in response to a nod, unseen by him, George slacked the sheet and Frederic actually hooked and played a fine mackerel just as the Eva was coming to rest, his satisfaction knew no bounds, and his good nature was unruffled when the cause of his sudden success was. presently explained.

Frederic had an extraordinary way with the toilers on life's way. To them, alike in his humble beginnings and brilliant successes, he always belonged. He could take liberties with the most radically disaffected among the fishermen. OnceI even thought that he would offend the usually imperturbable George, who is not without his moments of dignity. George had just related some more than usually prolonged history of Mevagissey society and paused, breathless, for our appreciation, when Frederic, a little less patient that morning, perhaps owing to some troublesome letter from his editor, said, "Say, "George, boy; that wasn't a right down good "story. You see, dear fellow, I'm paid a bit to. 
"tell stories and I know a d-d bad one when "I hear it!" Yet George never refers to his memory in terms other than affectionate.

Unhappily, his obstinacy was not always so innocuous to himself as when he persisted in missing mackerel on the wrong tackle. On one Sunday afternoon for instance, I took him over to "Troy Town " to introduce him to " $Q$," whether, as a surprise visit or by appointment I forget. At any rate, we found " $Q$," whom, though sufficiently my senior at Clifton to have left the school before I got there, I had known for some years, in his garden overlooking the beautiful harbour, and there we spend a very pleasant couple of hours, they discussing the impending completion of "St. Ives;" I listening, drinking tea and enjoying a sensation as near contentment as was proper to a day without fishing. Then, in the cool of the evening, we drove back to Mevagissey and found that the family had put our supper ready and gone to evening chapel " down under." Even as we walked up the little path to the cottage, the stern Wesleyan hymns sounded from the pious little valley. On the table lay a brace of fine lobsters from the store, but, alas, the sun had got at them before the cook, and they were tainted. A Bournemouth friend, one of the party, who had stayed home to write letters, joined with me in urging their removal to the back yard. There 
were a few trifles such as a pair of roast chickens, some fruit pie, cheese and saffron cake to make up, but poor Frederic would not forego the lobsters. We were only boys! He would show us how they ate lobsters in Utica. He did. He devoured the larger of the two and declared that it was delicious. We held our peace, fearful least the slightest opposition should provoke similar treatment of the survivor. Next morning at ten, when we went fishing, he was very peaceful on the bench in front of the cottage, mainly interested in rubbing his chest. That is the obstinacy which killed. Ten days before the end came, I received a wire from Kenley. I had not been there since one summer's day when some of us lunched under the spreading tree. Poor Crane, that other knight who went down in the fray with his emprise but half through, Oswald Barron, famous in the exposition of heraldic lore, and others were there then. This time I found Harold almost alone, the ghost of his former self. All that Saturday we discussed his convalescence, of which he was sanguine, and his plans for touring through Italy. I even wrote him then and there a letter to Dr. Anthon Dohrn, the eminent Director of the Naples Aquarium. Alas! he preferred Christian "science" to medicine to the end, and thus expired one of the few brilliant men it has been my privilege to call friend, on the very day when $\mathrm{Mr}$. 
Heinemann was to have published his last book. Gloria Mundi! What more would the glory of the world ever mean to him, whose large heart and large body we took to Woking and left a little heap of undistinguished ash!

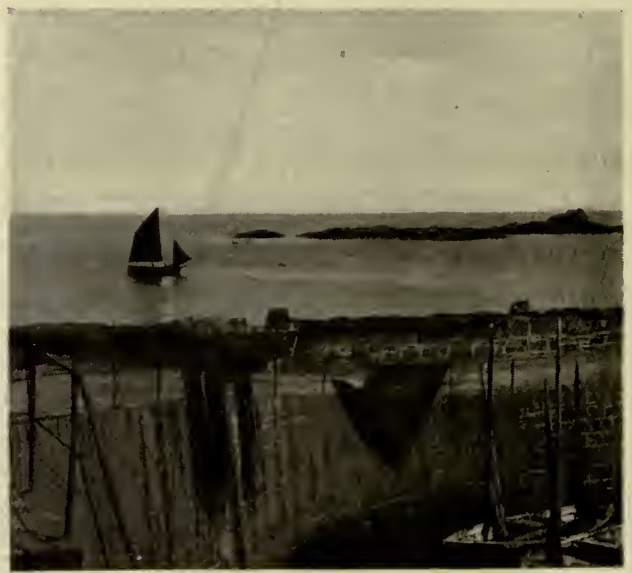


SCHNAPPER AND BLACK BREAM 



\section{V \\ SCHNAPPER AND BLACK BREAM}

Difference of Surroundings-Little Freshwater Fishing in Australia-Sydney Harbour-An Outing after SchnapperFishing in Broken Bay-Fallen Among Sharks-Schnapper and Sundries-Rods Unsuitable-Losing a Big Fish-Bright Colouring of Australian Fishes-Middle Harbour-Black Bream in Still Waters-"Berley"-Blackfish-Rods More Popular in Queensland-Possible Legacy of " Redspinner "Flathead and Jewfish-Sharks and Catfish in Moreton BayCalm-water Fishing-Rock-fishing-Dreadful Climbs-A Relation of Thackeray-"Cungevoi" - A Caution about Seaurchins-Leather Jackets-Failure to catch Hobart Trumpeter and Fitzroy Perch-Shooting Kangaroo and Duck-A Queensland Estuary and Quinine.

From the open waters off Mevagissey to the sheltered creeks of Sydney Harbour and Botany Bay is a far cry ; but the year 1895 found me, who. the previous summer had blinked from congergrounds up at the Great Bear, fishing for a change under the Southern Cross. The work done by energetic acclimatisation societies is gradually repairing the meanness with which Nature has. stocked Australia's rivers with fish. It is doubtful whether they will ever afford such sport as. the waters of Tasmania or New Zealand, where trout grow to dimensions, which we at home associate rather with salmon. There is, however, 
every prospect that, judiciously edited by man, they will yet give better fishing than Nature intended. They may indeed have arrived at that desirable stage already, for ten years of effort must be placed to their credit since I knew them. In those days at any rate, Australian anglers looked to the salt water for practically all their sport. Fortunately, the comparatively few indentations of that unlovely coastline are so capacious, withal so sheltered from rough weather, that landlocked inlets afford, where they are not overfished, all manner of excellent sport in absolutely still water. That Sydney Harbour itself gave much fishing even ten years ago could not be pretended, for the Australians, careful in all else to claim their inheritance for themselves, had with perverse apathy given over the fishing to Italians, the most wasteful fishermen perhaps in the wide world, with the result that the beautiful anchorage was denuded of its fauna. To-day, if the same policy has persisted, it must be nearer exhaustion than ever. The most plentiful fish within the Heads was the blackfish of Middle Harbour, where lads used to angle for it with rods, baiting their hook with a weed which they obtained from the quays. At odd times, too, I saw the crew of the pilotsteamer Captain Cook, stationed at Watson's Bay, haul trevally, just within the South Head, as fast as they could bait their lines. 
One Saturday in June, or rather as Saturday was giving place to its successor, for the great clock tower of the Sydney Post Office boomed forth the midnight hour, six or eight members of the Kuriwa Schnapper Club assembled at Circular Quay and filed along a gangway aboard a little tugboat, each greeting the coloured skipper as

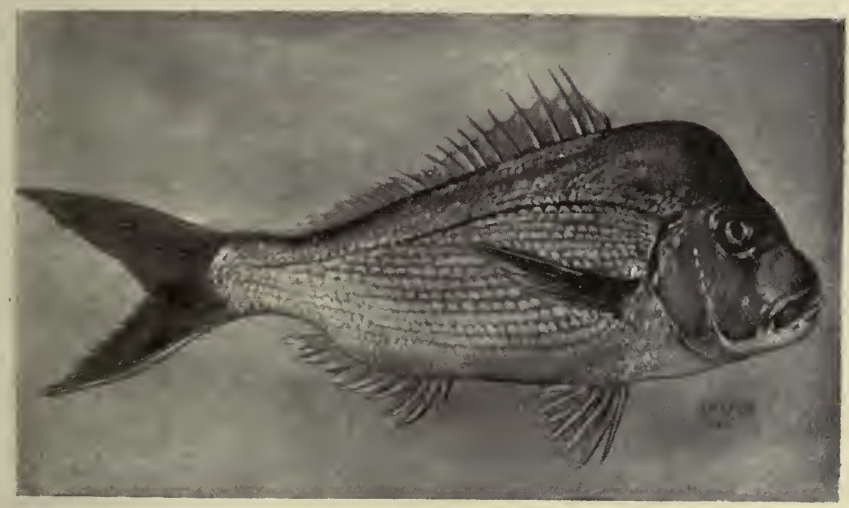

THE SCHNAPPER

he reached the deck. That son of Ham was a favourite with all hands and a wonderful fisherman to boot, usually catching two fish on his line to one taken on any other. A little delay was caused by two members arriving late. Both of them held positions in the Land's Office, but Government business could hardly be held responsible for their want of punctuality at that hour.

$10-(2272$ 
At the quarter. they came up together in a cab, and we got away just as the last of the ferry-boats came gleaming across from Neutral Bay. Past Garden Island and the anchored warships we dropped, and so to the threshold of the Ocean, where, in spite of the night being calm and what little wind there was blowing off the land, a gentle swell at once sent three or four of the party below, where they crouched in the narrow cabin and made believe to sleep comfortably. Although, in this upside-down country, what would have been almost the longest day at home was nearly mid-winter, the night was balmy and, as the Pacific lived for once in a way up to its reputation, the rest of us slept pleasantly enough on deck. As we passed under the looming brow of the North Head, the course was abruptly changed to the northward, and along the towering coast, broken here and there, as at Manly, by an interval of sandy beach, we went at half speed, since there was no object in reaching Broken Bay, our destination, before daylight. As a matter of fact, we were off the embouchure of the lovely Hawkesbury while it was yet dark, and for the last hour, before the tug lay to, I had been towing a new line astern in order to take the turns out of it. It was a stout spun line, dark green in colour, which I had bought, wound on a cork, at a shop near the Town Hall, and better for this ocean-fishing than 


\section{SCHNAPPER AND BLACK BREAM 131}

anything one could have taken out from England. I have since found that it is almost identical with the lines sold in America for tarpon-fishing.

The stoppage of the paddles, and the rocking of the boat when put broadside to the tide, brought the would-be slumberers tumbling up the steep companion. Good hot tea was served round from the boiling "billy," and everyone produced his own rolls and eggs and meat. An Australian exacts meat with every meal anywhere short of shipwreck. The meal is got through quickly with a running commentary of speculation on the weather, chaff, argument and prevarication, the not uncommon ingredients of angling intercourse. Leads and hooks are inspected again, and knots tested carefully, by lantern light, though the supremacy of night is already in question out to sea, where lie New Zealand and the dawn. Two of the crew are now busy cutting up the bait, a good heap of mackerel, squid and yellowtail, with a sprinkling of other fishes, old wives and grey mullet predominating. The last are put aside, for the mullet is peculiarly attractive to sharks, and it is not as a rule necessary to offer any special inducement to these spoil-sport vermin to hover round the boat when the lines are over the side.

And now, breakfast being at an end, the secretary of the club, a genial official in the Government 
Railway Department, makes nine small heaps of the bait, one for each member present and one for the skipper, and next chalks eight places along the gunwale on the port side. The skipper fishes from the bridge, and it is the particular care of him whose place is just beneath to keep his features

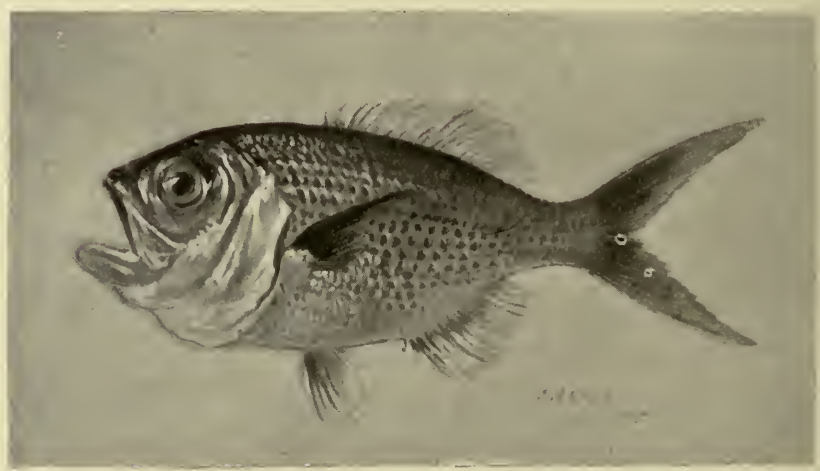

clear of fish swinging on their way aloft. By the time these preliminaries are through, day has got the upper hand, and we can see as far as the first bend of the Hawkesbury estuary. Everyone takes a place on the port side, according to the number he has drawn from a hat, and this, of course, gives the steamer a perceptible list. We are about"a"mile off the land, and the tug, her bow pointing to the beach, drifts north; all the lines will drift? out towards the south. Hooks are 


\section{SCHNAPPER AND BLACK BREAM 133}

baited, and, at a pistol shot from the secretary (since everything is done with some formality), down fly nine leads through the clear water to the reef, fifteen fathoms below us. Not more than three or four minutes elapse before three of them are being hauled back with that laboured action which indicates an objection being raised at the other end. To have got right among the schnapper at once seems too good to be.true, and so indeed it proves, for a groan from the stern, where these lines have been busiest, proclaims that the booty is not "right colour." " Right colour" means scarlet, the livery of the schnapper and of many other Australian fishes, including the little nannygai, which, after the schnapper itself, is the most welcome, since it is regarded as the harbinger of the larger fish, being found on the same ground and taking the same baits. Association of this kind between two different kinds of fishes is not uncommon, and at home we associate the garfish and mackerel in much the same way. In this case, it was not even silvery morwong, red pigfish or gaudy sergeant-baker; worst of all, it was a small school-shark on every line, females all of them with the living young writhing inside. And now two more lines are seized by sharks, one parting in an ugly rush that means a monster. Our master of ceremonies gives the signal "Up lines!" and, having acted on it, we steam away 
northward for three or four miles to try another reef that may perchance be free of such vermin. The plan answers, and, within a short time of our settling down to work again, two good schnapper, great red bream with a peculiar hump on the forehead (see photograph from an excellent painting in the possession of the Imperial Institute*) which gives the fish a stern, Roman-nosed profile, are kicking on the deck. Then several morwong soon join, and within a quarter of an hour everyone has caught something. Hauling a schnapper of five or six pounds weight is no child's play, for the water is moderately deep, the fish is a born fighter, and the pull on the line is of course increased by the broadside drift of the boat, as no anchor is down during the fishing. I never encountered at any rate outside of the excellent fish-room in the Australian Museum, any of the double-figure monsters that bulk so large in the glorious annals of earlier schnapper-fishing, but they must give fine sport indeed, even on a handline. A rod would never do for the work. I confess that I took mine out, something that I had had specially built at home for the work, with vague dreams of carrying the purism of the B.S.A.S. to the South Pacific. I also confess that the rod was never taken out

* For permission to take this I am indebted to the kindness of Professor Wyndham Dunstan, F.R.S. 
of its cover until, some months later, I used it for giant perch (which I never caught) in a Queensland river. It became quite evident on my way down the Harbour for my first schnapper day; several weeks before the occasion here described from my journals, that it would be hopelessly out of place. The sportsman should not be deaf to the teachings of local custom, for it more often than not has sound reason on its side. The obstinacy that knocks its head against a brick wall is not more disastrous than that which insists on grafting the angling methods of one part of the globe on the diametrically opposite conditions which may rule the sport in another. I was getting on fairly well on this occasion. I had caught three or four schnapper and several smaller fish, and had twice lost my hook in "New South Wales," for with the boat drifting over such rough ground, fouling the bottom means the instant rupture of negotiations. At last, I am fast in a monster. There can be no doubt of it, seeing the way my line is flying out, and some of the others pause in their own fishing to watch the issue. It is soon decided, and my visions of a record schnapper are dispelled. The gentleman at the other end after nearly pulling me over the side, suddenly sends me falling backwards by an unexpected trick of swimming up towards the surface and thus slacking the line. He must then have got a slack 
bight of the line and bitten it through, for he sank out of ken with the lead and hooks. Some guessed a shark; others thought it must be an extra large traglin; it did not seem to matter much, and I went below for another lead and some more line. Before I was ready to resume work, our old enemies, the sharks, had found us out again, for one or two members of the party were bringing the mournful heads of morwong and nannygai to the surface, the bodies having been severed as cleanly as on the operating table. The sun is now well up over the horizon, and its rays fall on little heaps of slain, each piled on the deck beside its captor. How different are those bright-hued fishes from the sober pollack and whiting of far-off Mevagissey! The eye almost wearies of their brilliancy and longs to dwell on a single grey fish like we used to catch at home, just as the old shellback, tired to death of brazen tropical skies, prayed for the sting of a Channel fog in his eyes. So, when one wanders in the luxuriant fern groves of tropical Queensland and watches the raucous-voiced parrots flying in all the pride of their dazzling plumage, regret for the sober but tuneful linnet and nightingale surges in the homesick breast. We do not, it is true, expect music from fishes, but in the matter of flavour, the smart dwellers in those warm seas are for the most part not comparable 
with the seedy-looking sole and dory of northern latitudes. A few, no doubt, are quite acceptable. The schnapper itself, the nannygai, the garfish are all fish that one can eat, but as a whole the Australian marée is poor food indeed. The brilliant raiment is easily accounted for if we remember that in the clear, sunlit seas of that continent pronounced reds and yellows are in reality more efficient protection from prying eyes than the darker coat of the cod and haddock would afford.

Again the signal to coil lines; and this time we steam away south, well satisfied, all but one or two incorrigible grumblers, with our morning's work. One more attempt is made, by way of using up what remains of the bait, on the Red Road, a reef off Manly, but without adding to the catch more than a few "squires," the schnappers that are to be, otherwise red bream of about two or three pounds weight. Then, as it is Sunday, and as no one has anything to take him back to Sydney, we spend the remainder of the day in the beautiful creeks of Middle Harbour, where we have more tea and food and try for a black bream. This meets with little success, for the most fastidious of Australian fishes will not be wooed without much preparation.

Let me try and recall, from a page in the July diaries, a day after black bream, exactly a month 
later than this schnapper outing. Those who believe, with Scrope, that sea-fishing requires little or no skill should accompany a party of Australian bream-fishermen, leaving Sydney by the early steam-tram or train, according to their destination, be it Botany, Como, or some other

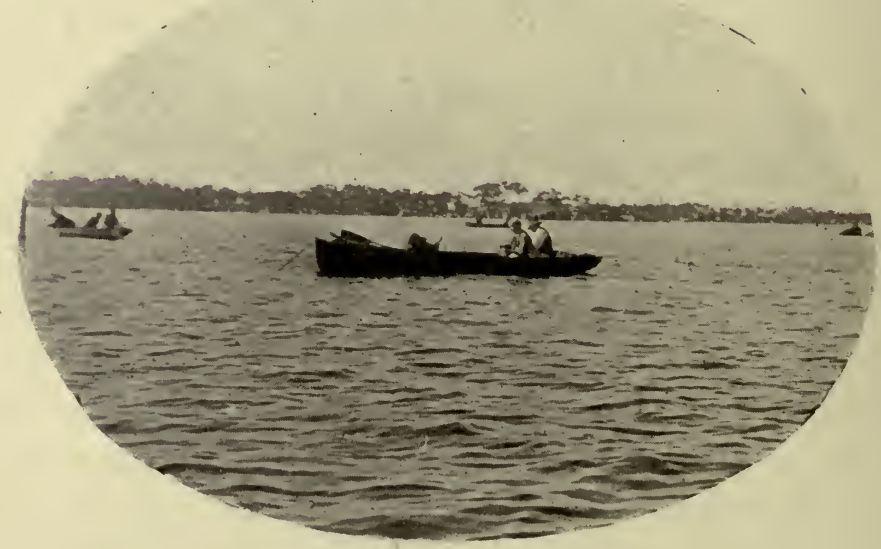

IN BOTANY BAY

beautiful sheltered water in the neighbourhood. A boat has been ordered by letter, for there is a run on all available craft every week-end. As a matter of fact, summer is the season for the best black bream fishing, but very fair catches are sometimes made in the winter months, and to-day, the still, fine weather promises success. The party consists of three, of whom two are experts 
and the third one who is ready to learn. Each carries a small handbag containing his lunch, or at any rate the solid part of it, his line, a very fine one with several feet of single gut and a single sharp hook, and a small jar of live prawns, socalled, though no larger than our common shrimp at home. One of the party, entrusted with that department, has brought a billy and tea as well as something of far greater importance in the day's proceedings, a bundle of the magic compound known as "berley." This Rabelaisian groundbait is cunningly concocted out of sour herrings, condemned tinned salmon, an inexpensive cheese that could never have been made for eating purposes, and as much bran as is needed to give consistency. There may have been one or two other equally disgusting ingredients; if so, I am glad to forget them. The smell of this outrageous preserve I never hope to forget, for the sour venom of it is still in my nostrils, and if ten years do not cure you of such a memory, it is ineradicable. In the enthusiasm of the moment, the frightful enthusiasm of the angler, which envisages lugworms, gentles and other beastliness as the accompaniment of a day's pleasure, hands are dipped in the mess as eagerly as were it a savoury Moorish kous-kous, and a small ball of it, well kneaded in the palm, is either thrown close to the line, or else pinched on the gut just 
above the hook. When the boat has been paddled, with as little fuss as possible, to some favourite spot close to the rocks, it is moored at either end by one who knows the locality, so that the baited hooks will lie just at the edge of a grassy mead where big bream lie and feed throughout the day. A little preliminary berley having been flung around as a general invitation, each hook is baited with a peeled prawn so that it shall be as far as possible hidden within that semi-transparent envelope. The line, of finest silk twist, is now uncoiled from its cork, and when sufficient lies on the seat, the hook, with a scrap of lead pinched on the gut to give it way, is swung as far out as required. It is then allowed to sink to the bottom, and the slack is gathered in, after which a keen breamfisherman would no more let go of it than of his hope of salvation. For choice, he would hold on to the line. It is even said that the cracks (not cranks) mortify the top of the forefinger with pumice in order to increase its sensibility, for the first overture of the bream is generally of the slightest, barely preceptible by anyone unaccustomed to the faint quiver of the line.

Readily as I recognised the futility of rods out on the schnapper ground, I thought then, and think still, that a roach-rod would be most appropriate to the capture of black bream. Lines, however, were the rule. It may be that in that 


\section{SCHNAPPER AND BLACK BREAM 141}

bright climate and clear, shallow water the apparition of a rod jutting out over the water would have frightened these sensitive fish. Whatever the objection, rods were never seen, their only use near Sydney being, as already mentioned, for blackfish. On the Brisbane river, a couple of months later, I found rods in much more general favour, a preference which it pleased me, correctly or otherwise, to regard as a possible legacy from my esteemed friend " Redspinner," otherwise the present editor of the Field, who resided for many years in Brisbane, and whose letters of introduction were a veritable "Open Sesame" at the doors of the hospitable Johnsonian Club and elsewhere in the most homely of all colonial capitals.

For black bream, however, rods were never used. As a result, with no telltale float to guide the eye to what was going on down below, the unpractised hand lost most of the best fish. First, it struck just that fraction of a second too late, which fishermen know so well as a fatal cause of failure. Then, nettled by the nimble evasion of the bream, it struck the same fraction of a second too soon, with the same result as far as the fish was concerned, only in this case the bait was saved for another essay. These Australian bream bite far more delicately than our sea-breams at home, or even those of Madeira or the Mediterranean. It may be that they have profited by the education 
imparted by amateur fishermen, learning how to cozen them. The larger the bream, the more finnicking as a rule is the way in which it nibbles, and it must be remembered that a skinned, uncooked prawn is no very difficult morsel to suck off the hook.

We have been fishing nearly an hour, and my Australian friends have half a dozen fish apiece. So far I have looked on. Ah! At length I have something on, not an undersized one either. Out goes my fine line over the gunwale, and I play the fish gingerly, as we used to play large mackerel in Cornwall. Foolish hints of the coming specimen bream fall from my lips. My friends say nothing, but think the more. He gives way at last; I haul him hand over hand, and next moment I have not indeed my specimen bream in the boat, but a hideous creature that I have never seen the like of before, something like a gurnard out of drawing. It is a "flathead," they tell me. As the information was murmured as I was ducking my head to get the hook out of its ugly mouth, I thought the speaker said something different, but took it meekly, for I felt indeed a little foolish with my "bream." The fish measured about eighteen inches long and was, they assured me, excellent eating. It looked like one of the faked mermaids that I used to see in a well-known curio store at Falmouth. Later in the afternoon, 
after the billy has sung its usual tune', I do indeed catch a few of the right sort, though of small size, and towards evening, after a long day of varying fortunes in different spots, we get a half hour of brisk sport, which gives us a dozen bream averaging half-a-pound, as well as a tussle with a big jewfish, which is hooked on one of my friend's lines and fouls the other in its efforts to escape, which it eventually effects, taking with it most of their tackle as a memento of the occasion. At first, it was taken for a shark, but its behaviour soon betrays its identity. Large sharks do, however, enter Botany Bay and even find their way into the rivers. In Moreton Bay, where, during a week's stay in Brisbane, I tried some unsuccessful fishing down near Eagle Farm, they told me that sharks, attracted no doubt by the city's abattoirs, were so plentiful thereabouts as to deprive the local supply of convicts of any desire to break free from their island prison.

This calm-water fishing provides an agreeable contrast from the rough and tumble of the ocean. Opportunities of fishing in sheltered salt water at home are restricted to a few estuaries. One or two, in Devon and Essex, as well as that of the lovely Mawddach, at Barmouth, I know well. Then there is the bay at Bridlington, where, on the upper lip of Yorkshire's strangely human profile, your boat lies snug from most winds. In 
Australia these opportunities are more extended, for all the great cities lie in these inlets along the coast, an arrangement which probably inspired the colonial enthusiasm for sea-fishing. Certainly the sport found adherents out in Australia long before it was general at home, and clubs and associations devoted solely to its interests, which are quite new in the old country, have flourished in Sydney these twenty years. Whether, as acclimatisation societies gradually stock the barren rivers with sporting fish, some of the amateurs will shift heir allegiance to other scenes inland remains to be seen. For all I know, such a change may have come over the spirit of the sport since I was out there, but in those days, with the exception of a little trout-fishing in Victoria, about which very few people seemed to know anything, it was a question of fishing in the sea or not at all.

There was a third kind of fishing, to which no reference has so far been made. This was rockfishing. At home in England, there was in those days comparatively little fishing from the shore, though it had some vogue in the neighbourhood of Aberdeen, and both the sandy shore at Aldeburgh and the rocks near Scarborough and Filey afforded winter sport to those who knew them. Of late years, amateurs at home have recognised the advantages of this beach-fishing, which often gives excellent results and at a cost no greater 


\section{SCHNAPPER AND BLACK BREAM 145}

than that of bank-fishing up the Thames. Bass of large size are caught throughout the summer on the beaches close to Folkestone Harbour and under the Castle Hill at Hastings, and at many another resort of Kent and Sussex, as well as at Sidmouth and Seaton, in the extreme east of Devon, bass are taken in this manner from the land.

I had never done any rock-fishing in those days worth speaking of, and the cliff-climbing in Australia was a fearful revelation. To clamber down the face of the North Head, or along the equally appalling wall of Australia beyond Coogee, was, even in broad daylight, enough to stop the beating of any heart but a goat's. The return climb from the pit in the dimmer light of evening, with fish to carry, and with the conviction that a false step meant a very hurried transit through a couple of hundred feet of air into the sharks' dining hall, scarcely bears writing about. Yet many such dreadful journeys I made, on any one of which it was Carnegie's Diplodocus to a new-hatched tadpole that I should break my neck. My guide on these occasions was the secretary of the largest angling association in Sydney, which had very courteously made me an honorary member soon after my arrival in the city. He was a relative and namesake of the author of "Vanity Fair," and for his kindness in giving up many days to showing me all the most appalling fishing spots 11-(2272) 
within ten miles I still render thanks to his memory, not untempered with amazement that such

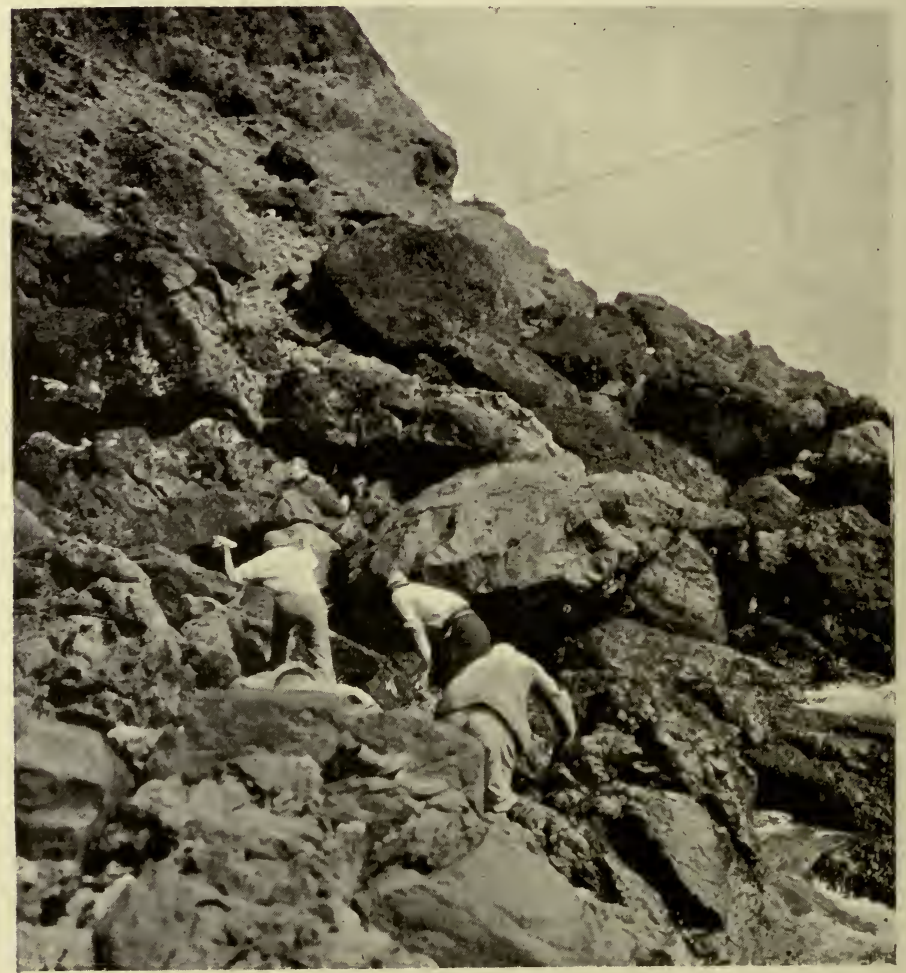

THE ROCK FISHERS' IDEA OF PLEASURE

adventures should have had no worse ending. I am no alpinist. I have not one drop of chamois blood in my veins, and if I were elected to membership of the Alpine Club, I should be found in a 


\section{SCHNAPPER AND BLACK BREAM 147}

crevasse with my face and feet pointing upwards. A sense of duty would impel me to take out a rope and ice-axe and gambol on the roof of the world, but the end would come quickly. Even on the mere hummocks that shut out Australia's desolation from the ocean, Thackeray was followed by a quaking disciple.

The ultimate and unworthy object of this suicidal monkeying with the steep places of earth was an immense fish called a "Grouper," which is apparently hatched from the egg weighing twenty or thirty pounds, at any rate if one may judge from the conversation of amateur fishermen out there, for I never heard any reference to a small one. This heavy, pig-lipped fish I saw now and then at the Wooloomooloo Fishmarket, which I sometimes visited in the early morning, walking down through the domain and swimming in the enclosed bath, through the gratings of which we always pictured sharks staring at us as the fox stared at the grapes. There was also at any rate one specimen in the Museum. Alive I never saw one, though the insidious Thackeray ever bade me hope against hope, and about once a week I uncomplainingly risked my life over some yawning abyss to gratify this silly ambition. Now and again my hook was held for a tense. moment in the boiling surf, and the line came back to me without it. The obvious aggressor was one of 
the sharp rocks that stand like teeth in every pool on that coast, but when my guide declared on each occasion that I had hooked a gigantic grouper, I had not, particularly as he obviously knew the truth, the heart to argue, so day after day we played the same game without ever diminishing the grouper population by one.

The way not to catch grouper, in which, thanks to Thackeray's able instructions, I was soon a past master, is, briefly, as follows. Our arrival at the water's edge was timed for low tide, and, after one or two experiences, he learnt to allow me about three times as long as he would have taken alone. The first thing was to gather bait, which, by way of mercifully lightening our load, Nature provided in abundance on the spot. Crabs, which, mindful of former narrow escapes, scuttled into crevices at our approach, were speared by the nimble Thackeray before they were quite out of reach. Another bait was known as " cungevoi," doubtless an aboriginal word like "morwong" and "nannygai." This was detached with the aid of a blunt knife from its submerged foothold in the rock pools. Of cungevoi I retain a less vivid memory than I could wish, but my impression after this lapse of years is that it was some form of sea-urchin. Touching sea-urchins generally, there seems excuse for a digression in view of a disagreeable experience I had during a recent 
visit to Madeira. I had pricked my fingers more than once in handling these creatures, but paid no further attention to the matter. Many days later, when homeward bound on the "Carisbrooke Castle;" I felt a painful throbbing in the middle finger of the right hand, and from the top joint the ship's doctor extracted about threequarters of an inch of sea-urchins' spine. It had apparently required over a week for the inflammation to make itself felt.

When Thackeray and I had gathered enough bait (we generally had about rather more than half of it left over at the end of the day's fishing), the next performance was to climb up again to some ledge commanding sufficient depth of water. It was indeed on all but the calmest days comfortable to get away from the extreme proximity of the Pacific, since the rollers of that ocean are curiously uneven, and every now and then a supreme effort looked dangerously near washing us off. Back we would toil, Thackeray going ahead, until the desired, but not desirable, spot was reached, often enough a miserable ledge that would just have accommodated an incubating guillemot. Then the hooks were baited, one with crab, the other with cungevoi, and swung out into the surf, a proceeding not unattended with the risk of overbalancing. Then we waited. The waiting was a great feature of those outings. 
There was a song, very popular in those unsophisticated days, a ballad they would have called it, of which the refrain ran-

\section{I am waiting. I am waiting \\ Just to tell thee how I love thee!}

Thackeray on the other hand, employed these interludes unprofitably in the narration of Homeric conflicts with enormous grouper. It was admitted that the very largest fish were less plentiful than in days of old, the stock having from all accounts deteriorated through over-fishing. After an interval, which varied from one to three hours, one of us would get a bite, and then followed the proud exercise of hauling a leatherjacket, contemptuously abbreviated to " jacket," or some other obscene looking fish (anything rather than that which we had come so far to catch) and despatching it in our precarious eyrie. The leatherjacket is one of the triggerfishes, a thick-skinned, flattened type, in shape not unlike a dory, and having a peculiar back fin, which it can erect at will. On one occasion I remember fishing with Thackeray not far off the Merivery sewer, in fact, as the wind blew from that direction, quite near enough. To make matters more interesting, a trifling shark that looked about nine feet long, but might, so terrified was 
I when making this estimate, have been ninety, seized both my hooks and the lead in its cavernous mouth and sailed unconcernedly out to sea. To save further trouble, and regardless of retaining such little esteem as might yet be mine, I threw the rest, winder and all, into the sea. Anyone holding on to a shark of that size while balanced on a slippery rock must be far wearier of life than I am even to-day. At that time, I had ten more years of its illusions still unspoilt.

Those old diaries, which have scarcely been opened since, recall other fishing days in Australia, many of them no more successful than these wicked strivings after grouper, that existed only in the vivid imagination of one who was no unworthy connection of the great satirist. There was the trumpeter-fishing at Hobart. At that season of the year, that is so say the end of the Australian winter, the waters $\sim$ round Hobart Sound had two kinds of trumpeter, the bastard and the silver. My guide, a greaser on the steamer that had brought me from Sydney to the pretty Sleepy Hollow that nestles under the shadow of Mount Wellington, begged me to believe that he would not put me off with the bastard kind. He was as good as his word, for we did not catch one. Incidentally, I may add that we did not catch one of the legitimate kind either. All we did get was a dogfish of no particular interest, and the 
day is starred in my journals merely as the Farthest South $\left(45^{\circ} \mathrm{S}\right.$.) of my wanderings with fishhooks.

Amid very different scenery, in a tropical climate, I made some equally ineffectual essays to get on terms with the Giant Perch of Fitzroy River. In that Queensland estuary we had been anchored for a fortnight, our insatiate steamer swallowing endless rations of wool down three hatchways. We got through the time somehow, chiefly shooting and fishing. We shot kangaroos on an island, but shooting one of those marsupials is not much more exciting than missing another. A few duck afforded prettier sport, and I recollect bringing down a high overhead bird with the choke barrel of my gun, and the body went swish into a dark and marshy patch of mangrove, into which neither the ship's purser nor myself cared to venture, fearing, no doubt, some deadly snake or hungry crocodile. Poor fellow! he died by his own hand the day we got to Tilbury, so he might just as well have retrieved the duck and taken his chance of a more honourable ending. This shooting not merely gave little result, but it entailed terrible tramps over baking plains composed of loose soil undermined by land-crabs, of a kind to make walking any distance a painful job. I therefore preferred as a rule to spend the day fishing for these giant perch from the little pier beside the lighthouse. From the vessel herself we could 
only catch small sharks and a bearded siluroid, both of which seized a baited hook the moment it touched the water and was carried by the swift tide along the surface. Neither gave any sport, or was of the least use to the ship's cook, and indeed killing such fish at all would, under other circumstances have been inexcusable. Owing, however, to some misunderstanding with the Rockhampton lightermen, the Rakaia was delayed an extra ten days in that mournful estuary, and, as we were left absolutely idle, the usual master of ceremonies found mischief ready to our hands.

So to the lighthouse-keeper I turned in my trouble, and found him a friendly fellow, like all his class. Being cut off from the society of your fellow men during about eleven months and three weeks of the year does not induce a churlish mood when a rare visitor invades your official solitude. This particular guardian of the fairway was so obliging as to net me some grey mullet and "skippers " for bait, and every morning he had a bucket of them ready, all as lively as grigs. And every morning, I put one on the hook and lowered it beside the piles, and sat there until it was time for tiffin, and in due course I was so tired of waiting for perch that I would have welcomed sport with a crocodile. Every few minutes the water made a gurgling sound among the piles, and the lighthouse-man 
assured me that it was the snorting of a perch that had caught sight of my bait and would certainly seize it in a minute or two. At first this sort of fooling found me credulous, and I braced myself up for the coming fight ; but such "Wolf!" cries soon lose their first novelty, and I developed a peaceful mood, indifferent to perch or anything else equally remote. Still, it was more agreeable on the pier than on a steamer overrun with unclean lightermen and bawling stevedores, and at low tide it was always amusing to watch the little mudskippers, true fishes out of water, hopping about at play among the uncovering mangrove roots. That was all. I had practically comforted myself with the conviction that the much talked of giant perch of the Fitzroy was a scaly myth, but this pleasant explanation of my failure was dashed on the last morning of our stay. Even as the last hatch was fastened down, the last bargee bundled over the side by an irate baggage-officer, the order about to be given to stand by the anchor, we were hailed from a bend in the bank, and a little boat shot out with the lighthouse-keeper, who had a small offering for me in the shape of a perch that he had caught at daybreak. It weighed considerably over $30 \mathrm{lbs}$. after it was cleaned, and proved excellent eating. Such a fish must have given fine sport on the rod, and not to have caught one was my one regret for as desolate and malarial 
an anchorage as even a professional undertaker could design. Never have the caprices of travel landed me in a worse hole, at any rate for so long a period. We spread quinine in the form of powder on our early slice of bread-and-butter as gladly as if it had been foie gras, and only such precautions, I firmly believe, saved the whole company from going down with fever.

That ended my fishing in Australia, with the exception of one or two stray perch-like fishes, which I caught at various anchorages within the region of the Barrier Reef. These halts, however, were few and far between, and less time was spent in catching fish than in watching them, from hammerheaded sharks down to beautiful little painted kinds that sported amid the corals like gaudy humming-birds among rare tropical flowers.

At Thursday Island we fell in with some pearl divers, kanakas, of course, and their white overseer. Two of the divers had a pretty fight, at the end of which part of a knife blade belonging to one was hidden in the buttocks of the other, but no serious damage seems to have been done. A most amusing fellow here came on board in the second class, one who had spent most of his life loafing among those lotos-islands. $\mathrm{He}$ was going with us as far as Batavia, and expected to return thence in a month's time. Once man gets within the spell of those South Seas, there 
is no reclaiming him. Long talks I had with this character. He had read a good deal of such literature as appealed to him; Stevenson, Louis Becke and others I remember his referring to. He made game of those writers who assure the reading public that life in the South Sea Islands is one long business of gallantries with native princesses, who are invariably represented as falling head over ears in love with the first coarse Englishman (very few of the other kind ever go there) who pays them attention. They are, he told me, rather amorous young women, but it is entirely for their own countrymen that they keep their favours, save where these were a matter of barter. From what he said, I suspect that Mr. Kipling's advice

"The things you will learn from the Yellow and brown,

They'll 'elp you a lot with the White,

belongs to the realm of pure biological speculation. At any rate, I know too little of his natural history to say whether his advice is the result of personal adventure.

One more kind of fishing we tried on the way home to Europe, and, since I have promised not to gloze the failures, it shall here be set forth, though it will be long again before I go to so much trouble with so slight a chance of success. 
Long had I treasured the details furnished by a sporting correspondent of the Field, a naval officer, of stupendous fishing in the Indian Ocean and Red Sea when under way. Albicore, bonito and other splendid surface-swimming fishes had been taken by this method, and, as we were bound for those hallowed waterways, in a vessel moreover which did nothing to emulate the expedition of a mail-boat, I resolved to try my luck. The dobash of the B. I. Company at Batavia procured for me an immense bamboo pole, the which, with the sanction of the skipper and by the help of a well-bribed quarter-master, was rigged up in the correct fashion, so that it projected, seemingly for about a quarter of a mile, from the starboard side, a gigantic fishing-rod indeed. A brand new line, a treble hook dressed with bunting to imitate a flying fish-it might just as well have been a drowned immature hippogriff-and a small bell completed this amazing outfit. The eight knots, which had sufficed our unambitious old tramp vi $\hat{a}$ the Queensland ports and Barrier Reef, were, on leaving Tanjong Priak, increased to nine, probably rather too fast for success; but the skipper, though not hostile to the idea of fresh fish in the saloon, declined any further concession. We could fish at nine knots, or " do the other thing," whatever that was. The autocrats put in charge of cargo-boats " fitted to carry a few 
passengers" have a charm of manner that distinguishes them from the other personages of earth. The only construction we could put upon "the other thing" was whist all day and pegs all the evening; and, as these had been tried to exhaustion, we resolved to give the fishing a turn. Over went the flying-fish on the day that Java faded from sight, and away it trailed in the direction of that spicy island, bobbing and dancing in the creamy wake of the pulsing screw, and the lissom bamboo bent to the pull of it. Then the line and bell were so connected that as soon as a fish threw additional strain on the former it set the latter ringing. The first time, the bell remained silent, and after waiting with waning enthusiasm for three or four hours, six of us, passengers and crew together, had half-an-hour's back-breaking exercise getting the line in, so appalling was the tension. Next evening, when some slight finishing touches had been put on the " fish," till it now resembled a waterlogged bird, it was once more cast loose to dance before the eyes of ravening monsters of the deep. It did its work, but we never saw it again. Just as we were busy at dinner with some more than usually uninteresting dish, tinkle went the bell, and, without apology to the Captain, who would not have left his food if the four beasts of the apocalypse had sat down at the saloon table, we dashed on 


\section{SCHNAPPER AND BLACK BREAM 159}

deck, just in time to see our precious bamboo bending like a sapling in a gale. Next minute, we were all hanging on to it, and for a few glorious moments of suspense, we felt the desperate play of something lively and ponderous out in the darkening foam, probably one of Lieut. Howell's dolphin or kingfish. Then the ship's nine knots and the efforts of the fish combined with a result that sent us tumbling on the deck, for the line parted, and when we were on our feet again we hauled in the slack. That was our last attempt. "Flying-fishes" cost us half-a-crown apiece, nor, seeing how much they took up of their maker's time, and what fearful objects of art they were when completed, could they be called dear at that price. The game was, however, voted not worth the flying-fish, and the ocean-rod joined the list of the ship's belongings, as I was in no mind to take sixty feet of bamboo on a cab through the streets of London. 

WITH BASQUES AND MOORS

$12-(2272)$ 



\section{VI \\ WITH BASQUES AND MOORS}

Biarritz in March-Discouraging Reports-A Pelota Match before the King of Sweden-Two Kinds of Broken FrenchGitouche-Toujours D'Artagnan-Good Whiting-fishingPeculiarities of Basque Fishermen-A Little AltercationFishing at Tangier with Abslam-His Fatalism and Patience -With José, who lacked both-Blackmouthed Dogfish at Casablanca-Barbel in the Wad Tensift near Morocco CityWater-tortoises-Grey Mullet at Mogador.

THERE are fishing expeditions which hold their place in memory not so much by reason of either success or failure as for having brought the amateur in touch with the working fishermen of many nationalities. Of three or four such a word may be written down in this place.

On a perfect day in March, 1899, I found myself on the quay of the Port des Pêcheurs at Biarritz, imbued with the determination to get fishing of some sort, for the Atlantic was invitingly calm, and away in the middle distance to the north, where steamers moved in and out of Bayonne, the sardine fleet was at work, working havoc among the shoals.

The sea-fishing reports that I had gathered at the Hotel d'Angleterre discounted hope. The femme de chambre could promise no sport until August, the month, she said, in which rich Russians arrived. I wanted whiting, not rich Russians, and 
I turned for consolation to the lift-porter. All that he could do was to suggest possibilities for June, but in June all going well, I should be residing in Marrakesh, the southernmost capital of the empire ruled by him whom men call Abdul Aziz. For several days I hung about on land, where, since I aspired neither to play golf nor to watch others shoot pigeons, the least boring afternoon was spent at a pelota-match between Basque and Spanish champions, which had been arranged in honour of the King of Sweden. That most courteous monarch arrived late, and quite inadvertently an hotel acquaintance and myself sat immediately beneath the bench reserved for the Royal party, the only distinction of which was a covering of red baize. When the entire assembly stood up, and the King entered with a bevy of beauty and a number of gentlemen in attendance, we realised our mistake and were about to retire, when one of the gentlemen in waiting assured us in French that His Majesty begged that we would not " derange ourselves." We did not, and got an excellent view of an interesting game in consequence.

Yet the sea was calling to me just beyond the rocky little harbour, and I was never deaf to that call yet. That was what brought me to the quay, and a friendly customs official, with an eye for a bock, soon accosted me in execrable French and 
got, if anything, worse in return. Fortunately, we were neither shy, and an immediate understanding was arrived at, as the result of which he did not go home parched with thirst, while I was presented to an immense, jovial, olive-skinned

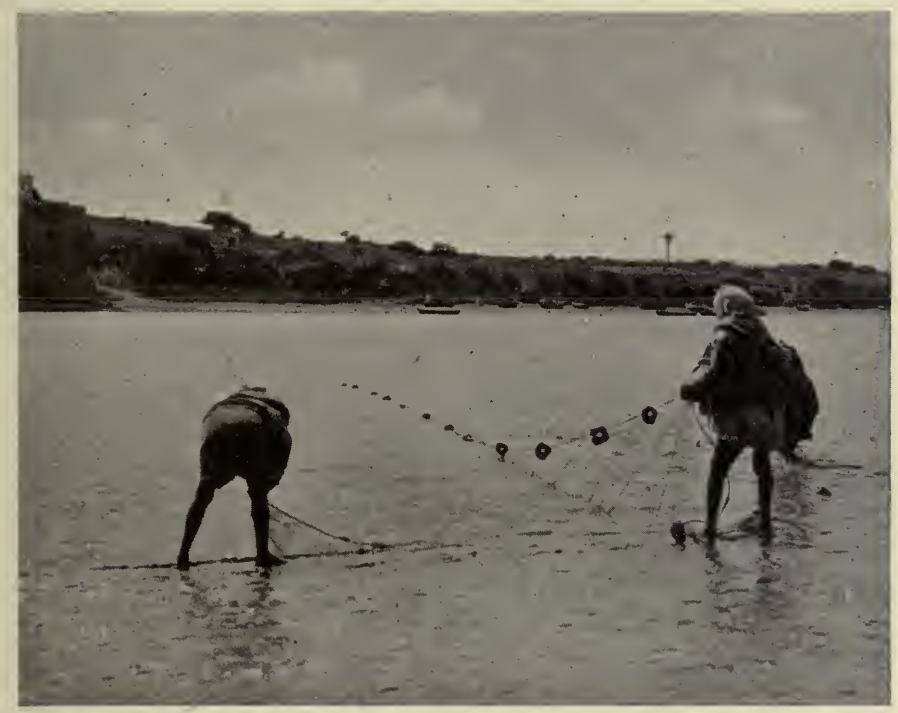

CATCHING SHAD IN THE UM ERBEYA

Basque, who answered to the name of Gitouche and stared at me through huge, horn-rimmed goggles. I could, said Gitouche, catch as many whiting as I had a mind to, if I would come out that afternoon at two, as the tide would then serve. His price? Bah! A few francs to the men; for him, he was pleased to show anyone sport. 
But-if he could have a trifle now to get a bottle of wine for the men to drink Monsieur's health in ... ! For an imperceptible second I hesitated. At home, it had been my invariable rule that the men could drink what they pleased after they had put me ashore, but on board it was always ginger beer, cold tea or water. The Englishman, who rules over so large a slice of the world in spite, not because, of such virile tastes, is apt to grow quarrelsome over strong cordials, his thirst growing with opportunity, and I never yet had any use for a drunken man in a small boat. For a moment, then, I demurred, but, just as Gitouche was turning away hurt, I relented, and my confidence was not abused. The small bottle of thin red wine, of which each of his crew had one, half emptied, at starting, could not have done much harm beyond bringing swift remorse to a stomach unused to such ordeals. Nor was the actual remuneration for four hours of the services of a crew of three excessive. Gitouche eventually asked eight francs and got twelve. Henceforth I was treated on that boat with as much ceremony as if I had been one of the Grand Dukes out of season.

Making my way down to the harbour after lunch, I found Gitouche standing at the foot of the greasy steps, ready to hand me into a long and roomy boat, in which two merry vagabonds 
sat at the oars. Stroke was called Prospère, the other D'Artagnan. I vaguely resented D'Artagnan, although we were within hail of Gascony, for London actor managers had been a little prodigal of musketeers the preceding winter, and it was irritating to find the swashbuckler even in a little boat off the Spanish frontier. As a matter of fact, though the name is far from uncommon in the south-west corner of France, I fancy that the whole trio went by nicknames, for which, like most southern races, the Basques have a perfect mania, continually ignoring the names given at their baptism.

We soon got clear of that beautiful little harbour, passing beneath a rocky archway, from the summit of which several sportsmen were fishing with rods of great length, and the men rowed to a spot about two miles out, opening up a fine view of the Spanish mountains to the south. I had thought the promise made by Gitouche somewhat suggestive of the nearness of Gascony, but it was warranted by the results, for during the next two hours we caught rather more than six dozen fine whiting. The bait was fresh sardine, and the men used, for professionals, surprisingly fine gut tackle.

These Basques are light-hearted fellows, fond of the English, the geese that lay them golden eggs until the advent of yet better layers from 
the Neva. They hold themselves aloof from the political quarrels entered into by both France and Spain, and at a time when none too friendly relations existed between either of those Powers and England, the Basques were uniformly courteous.

With my three knaves I went out more than once after the first essay, always making a good catch of whiting, never, strangely enough, hooking any other kind of fish. Gitouche, as the only one who spoke French-a French, beside which that of "Stratford-atte-Bow". was the pure vernacular of the Faubourgs-alone had the distinction of conversing with the guest, but among themselves they were loquacious, talking that curious Basque patois with so much gesticulation and heat that more than once they seemed on the verge of a quarrel that could only end with knives. Appearances, however, were deceptive, and it was one morning when they seemed as harmonious as kittens purring in a basket that the patron suddenly brandished a tiller handle and with it fetched Prospère a blow over the kneecap that made him squeal. Justice having been done, he calmly removed his goggles and breathed on them, doubtless to ensure yet better aim on the next occasion. It was evident that Prospère had provoked this sally, for he made no attempt to retaliate, but merely went on fishing with a subdued chuckle, as if, whether his kneecap were 
whole or not, he had told the patron home truths that nothing could unsay. I asked Gitouche what was wrong, but he said merely that Prospère was a pig and that his mother-but I forget the rest. My next outing was in the crescent frame of sand and white city that borders Tangier Bay, not a hundred yards from the crazy little pier that juts out beneath the Custom House, between that in fact and the anchorage of the Gibel Moussa, I sat in a tiny coble with Abslam, the Moor. He was a sinewy fellow, six feet and more in his yellow slippers, and the rest of his wardrobe would not have weighed more than my straw hat. Unlike the other Abslam, his hair was shaved so close to the round skull that the oak would have got no purchase. He was a fine fisherman, was Abslam, better than his little son, who came out apparently for the purpose of being sick over the bow, having carefully left our live shrimps in the full glare of the April sun.

Having rebuked the offspring of his loins in about five-and-twenty crisp sentences, Abslam turned to me and explained that Allah had in his infinite wisdom taken from him the apple of his eye, a son of great promise by an older wife, leaving him the object that now lay prone in the bottom of the boat in the place of the departed. Mektub! It was written! But it was a woundy bad bargain, all the same! 
Very pretty sport that calm bay gave me; a daily basket of small sea-breams, wrasse, bass and red mullet, two of the last (Abslam called them "Sultan-el-Hoot," king of fishes) within ten minutes, the first and last red mullet I ever took on the rod. Abslam caught a third and a dory, and all four fish were welcomed that night at the hotel.

In addition to undoubted skill, Abslam had the patience of his race. Above most races are the Moors fitted for the arts of fishing and diplomacy, having inexhaustible stock of both patience and cunning. Abslam baited a hook well and rarely did he miss a fish. If he did, it was the will of Allah; it was fate.

Far different was the temperament of José the Spaniard, with whom I now and then went out for a change. He was as good a fisherman as Abslam when he liked, but he was a lazy chewer of cigarette stumps and spent as much time in expectoration as Abslam in prayer. As for his patience, it was only excelled by his beauty. When he missed a fish, or went long without a bite, he mouthed profanities that made the flesh creep. It might be the will of Allah, but Allah ought to know better! "An arrant knave in common dealings and very prostitute," as Swift once wrote of Lord Rivers, was José, yet a brave, devil-may-care fellow, who would have stuck his 
knife in my back with the skill of a licensed vivisector, or jumped overboard to save me from drowning, according to his mood and the occasion. The fishing he liked best was from the rocks, with a comrade, the comrade holding the rod and José lying at full length beside him and throwing. groundbait at the line.

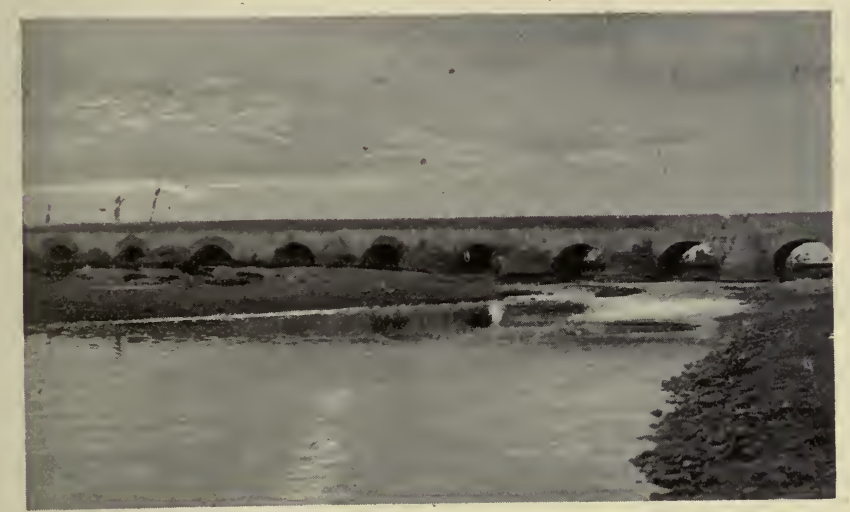

A BRIDGE OVER THE TENSIFT, MOROCCO CITY

At Casablanca I once fared forth with a crew of devout Mussulmin to catch bass, and in its place caught blackmouthed dogfish (Pristiurus), a small and interesting shark, occasionally trawled in deep offshore water on the British and Irish coasts. Not having previously encountered the species outside of museums, the episode was not unwelcome, but the capture of any dogfish is not 
a pastime to occupy a second afternoon in one week.

My only fishing in the interior of that fascinating country was for small barbel in the Wad Tensift not far from Marrakesh. Thither, attended by the regulation soldier-in Morocco, you take a soldier with you even to go birdsnesting-I occasionally rode at four in the morning, before the sun had power to sting, as sting it can in those countries towards the end of June.

At the yellow bridge of many arches, two or three miles outside the city gate, we dismounted, Said making the barbs fast to a tree. Then, while I put my rod together, he was all over the place after grasshoppers, four out of five of which he zealously crushed with his fez, thereby rendering them useless as bait. A fat and lively grasshopper is a capital bait for these barbel, and it has the advantage of being obtainable by the waterside.

The level of the Tensift, as of all the few considerable streams in that empire, varies considerably according to recent rainfall, but even in the drought of June it was always possible to find a deep pool or two beneath the arches of the bridge. A grasshopper, so lively as almost of itself to sink the float, proved irresistible. Unfortunately very few of the fish seemed to exceed a curiously uniform weight of between half and three-quarters of a pound. I now and again, looking from the 
bridge sheer down in the water, saw the dark form of something larger, but on no occasion contrived to tempt one. Indeed, the only time the interest was varied was when an occasional water-tortoise seized the hook, sailed with a peculiar twitching action, probably due to the wriggling of its head, across the pool and then bit through the gut. I had no gut capable of holding these reptiles, nor indeed was I particularly anxious to retain them. The jaws that could bite through fairly stout gut as if it were cotton did not invite liberties. It cannot be said that this morning fishing in the Tensift was of an exciting order. Rather as the excuse for a somewhat longer ride than merely out to the great tank or the parade-ground did it commend itself. I can even now recall the scene in all its details. The horses fidgetting fifty yards off ; myself huddled close to the bridge, so as to stand in the shadow of the masonry; and Said, the picture, as indeed he was otherwise the presentment, of as complete an idiot as any servant I ever had, leaning half over the parapet, gaping whenever the float went under, grinning as each fish came flashing through the air.

The last fish with which, as a parting gift, Morocco presented me, were a brace of grey mullet, which I caught in five minutes fishing over the ship's side at Mogador. I had ridden in from the interior only the night before, and the Orotava 
was getting her anchors up almost as we stepped on board. A large shoal of grey mullet could be seen feeding madly round the condensing pipe, and over these some children vainly brandished hooks baited with meat! Quickly procuring a piece of bread, I was just in time to catch two as the screw took its first turn and dispelled the shoal. Else, had I been an hour earlier-and I had only been loafing at the hotel, as I now reflected with bitter regret-I might perhaps have made the record catch of mullet of my life. That is the grey mullet all over. You make conscientious and elaborate preparations for its capture and never see so much as a flick of its tail. Then it gathers in hundreds alongside your steamer just as the wretched anchor-chains are groaning through the hawse pipes. Kismet!

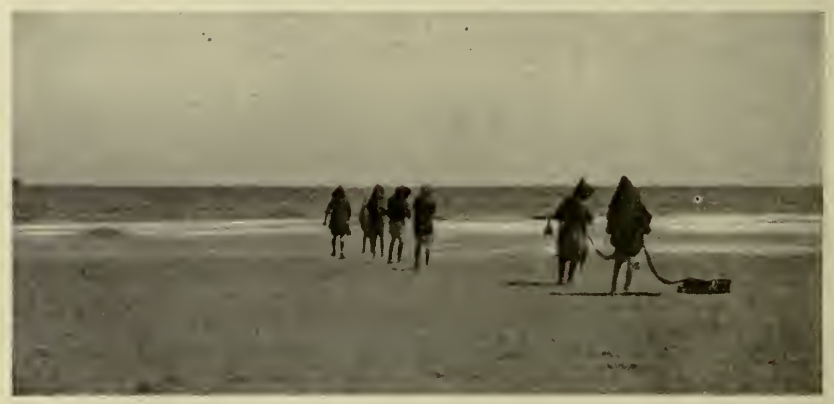

MOORS HAULING A SHORE-SEINE. 
BASS AND MULLET 



\section{VII}

\section{BASS AND MULLET}

Bass and Mullet Compared-Luck of Young FishermenA Mullet Caught on Pollack-tackle-Another on a LegerThe Bass in Two Different Moods-Night-lines-Better Sport on Live Bait-Attractions of Fishing in Estuaries-A Morning's Sport in the Teign-Memories of that River-Difficulties with Buoy-chains and Weeds-Trouble with other Fishermen - Remedies Indicated-Bait Not Always Procurable-The Grey Mullet-Its Appetities and Habits-My Repeated Ill Luck-Visit to Mr. Gomm at Margate-Experts beneath Margate Jetty-A Day's Success-Importance of Groundbait -A Mullet at Last-Advantage of Local Guidance with Mullet and Bass.

WHAT the schnapper and black bream are to the amateur fisherman of Australia, the tarpon and tuna to the American, that are bass and grey mullet on the coast, and particularly on the south coast, of England. Luck and chance, not always two words for the same factor, play their part in their capture, as indeed in all kinds of fishing, but, other things being equal, they are, when fullgrown, about the most tantalising fish in the sea. Either in its first youth may be gulled by little truants from school, who use "tiddler" tackle from the quays of Plymouth or Southampton.

13- -(2272) 177 
Either, even in its years of discretion, may be exceptionally hungry and under such stress of appetite lose all judgment and fall a prey to the clumsiest of deception. Again and again some small lad, fishing for the first time in his life from a pier, hooks a bass that experts only dream of. $\mathrm{He}$ catches it (according to the books) with the wrong bait and at the wrong stage of the tide; but he catches it, and the rest does not much matter. His tackle is a shilling handline, bought at a toyshop; but his bass beats any taken by yonder master of the art, whose rod and reel alone must be worth a five pound note. These are the chances of war. To the artist, of course, the capture of such a fish on the finest of tackle would give a thrill that he could never experience from the use of cheap, coarse gear ; but the lad is in all probability no artist, and his joy knows no bounds. The grey mullet of large size is less often betrayed by such rough and ready overtures, but now and again it too, most cunning of salt-water fishes, falls to the poorest temptation. My friend, Surgeon-General Paske, was on one occasion pollack-fishing from, one of the piers at Dover, I forget which at the moment, with the usual paternoster of twisted gut and baiting with ragworms. Suddenly he found himself in a good fish, which did not bore after the fashion of a pollack, but circled in eddies nearer the surface. 
Carefully, as only an experienced fisherman could from such a height, he played his fish and presently he had the satisfaction of landing a fine grey mullet weighing four or five pounds. And this is the fish that I have before now trained fifty miles for in vain! In ordinary circumstances, of course, he would be a very foolish person who brought out pollack tackle in the expectation of catching grey mullet with it, but the pangs of hunger may once in a way lend deadly attraction to a hook and bait that would on other occasions be rejected with scorn. I was also told of a parallel case at Margate, where an obvious novice one day captured two fine mullet on leger-tackle, baiting with herring, while an expert, fishing close by with everything appropriate, entirely failed. Much also depends on the surroundings, in which the angler seeks his fish. There is, for instance, all the difference imaginable between the conditions under which one bass may prowl along the beach for such offal as accumulates near-low water mark, its sight impeded by the thickness of broken water, its hearing confused by the roar of the surf, all its senses, in fact, deadened to the presence of danger and intent only on satisfying its hunger, and another bass, which chases the sand-eels in the clear still water of a tidal estuary. The latter fish is conscious of every sound and every shadow, of which fishes have cognisance at all, and will be 
tricked only by a cunning that matches its own. Anyone trying to catch an estuary fish of that kind with ordinary pier tackle and herring-bait might just as well fish in the High Street. On night-lines, it is true, which are, save as sources of commercial supply, iniquitous contrivances, even an estuary bass will fall a victim, particularly when the hooks are baited with such a delicacy as soft crab, but night-lines have no place in the sportsman's outfit, and as long as daylight lasts these river-bass will be found to require very fine tackle and, if possible, live bait. The latter is to be preferred, not only because the fish as a rule like it better than any other, but even, as I think, because they show better sport when taken on it than if the bait were squid or dead fish. In arguing the question, it is no doubt fair to make allowance for the fact that the use of live bait implies also the use of fine tackle and little or no lead, both of which conditions conduce to the best of sport, whereas the other baits are used on the bottom with a heavy lead, the inertia of which deadens the play of the fish. Even so, however, I regard a bass which seizes live bait as in its best hunting mood, on its mettle, more inclined to put up a good fight than one that is merely scavenging along the shore or round a pier. It is the difference, in short, between the spirit of a corsair and that of a dustman. For this reason, 
I would always for preference use live bait for game fish, like bass or mackerel, whenever it could be obtained. The grey mullet, on the other hand, though attractive by reason of its wary behaviour and strength when hooked, is not, so far as we know, a fish of predatory habits and must be angled for with paste or rag-worms for bait.

With almost consistent ill luck, fragments of which have been referred to in the foregoing pages, I had sought the bass for about fifteen years from a dozen piers and foreshores and in more than one estuary, when a whim took me to Teignmouth in the summer of 1900. I had often looked out on the tempting blue river with the background of red cliff, when travelling to or from the West country, and had been puzzled as to what they fished for from the boats below the footbridge. Now, I know, for in that hallowed quarter of a mile of brackish water I have, during the last six summers, caught practically all the bass I ever got in my life, and nowhere else have I found the match of this peaceful and delightful estuary fishing. It is creek-angling, as in Australia, with a grander fish for your object than the small black bream or gross flathead. It is sea-fishing without the tossing; it is river-fishing without the stagnation. Let me describe a typical morning's fishing in this estuary, where sport with the bass has this further advantage for a professional man that he 
can get the cream of it in a couple of hours, morning and evening, when the tide is about half way up.

It is four o'clock on a July morning. The sun is still down behind Exmouth, but, as we walk the few steps to the boathouse, the haze that broods over the Den, the cloudless blue sky overhead, the stillness in the air, all forecast a scorching day. And on a hot morning, even before breakfast, we have reckoned; otherwise, a suit of ducks over one's pyjamas would be light attire for early morning on the water. As a matter of fact, until the sun gets at us over the elms, there is a nip in the air that occasionally takes our thoughts to the long coat that hangs behind the door.

A little after four, having roused Cox, who, like the May Queen, has to be awakened early if he is to get up at all, and given him time for his inevitable cup of stewed and syrupy tea, we are snug in the Hirondelle, our trout-rods and collars of single gut ready for action, and a baitbox towing alongside with a score of dashing sand-eels fresh from last night's seine. It will be high water soon after nine, so that the tide must have turned an hour ago, and indeed it is draining perceptibly in from the sea, as witness the boats that have swung round to it. Yet there will not be enough for an hour at least to take our boat along stern-first, which is the ultimate 
position in which we have to fish for the bass on the rough ground above the yachts.

We shoot out from the landing place and just above us lie great merchantmen in tiers, flying

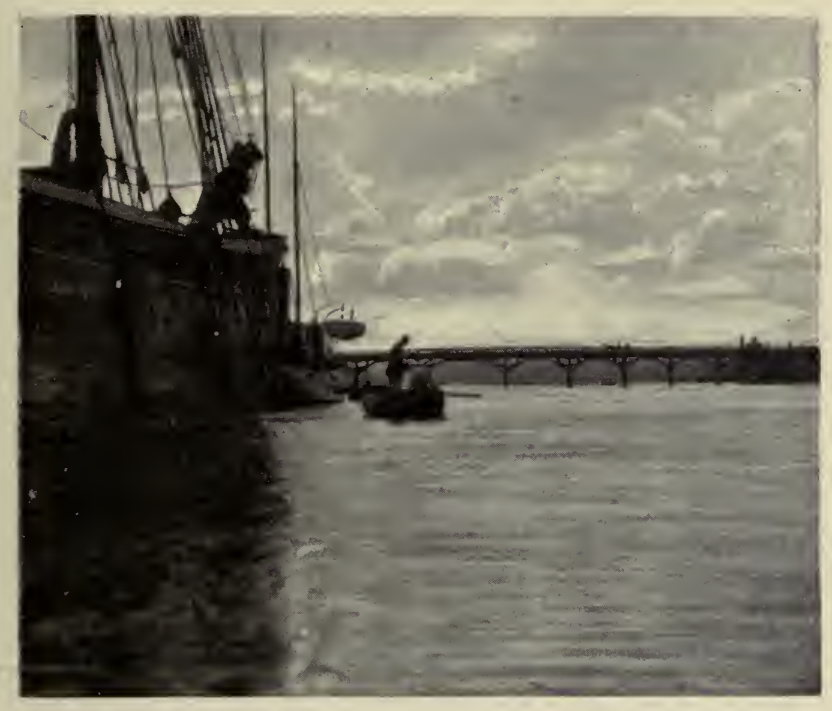

DRIFTING BESIDE FOREIGN HULKS

the flags of half a dozen nations. Here are timber ships from the. Baltic ports ; Italians, come for a cargo of Newton's clay; coasting vessels from Fleetwood or the Bristol Channel; a Thames barge alongside a converted trawler from the Humber; as many types of craft almost as one sees in these latitudes. At so early an hour this 
fleet shows no sign of life, unless indeed a mongrel cur barks at us from the bows of some vessel close to which we pass, to be chastised later, no doubt, for having disturbed the sleep of everyone on the river. Later, when we have fished for a couple of hours, there will be activity and bustle, sleepy lads scrubbing down the decks, men ashore hailing whichever ship they want to board and, if not quickly fetched off, adding to their humble petition and prayer such piercing expletives as might reach the ferryman of Styx. Ere we go home to breakfast, the whole boiling of them will be on deck, and a fight with a good bass under a ship's side will collect a crowded audience and a polyglot of encouragement, chaff, condolence. . . Per Bacco! ... Aller Wetter!... Got theby-! Alas, that one should have to bowdlerise only the English!

As first we approach the lowermost tier, however, all is silence. We cannot drift the way we like until the tide runs swifter, so Cox will for forty minutes or so row the boat slowly and in circles abreast of these lower ships and the railway quay. We shall not hook anything large, but our baits are over the side now, and one never knows. Ha! what was that? A twitch of the rod top... another . . . down it goes, for the slight turn of the wrist has flicked the sharp hook in beyond the barb, and the bass is fast. The reel sings a 
modulated hymn of praise, not raising its voice as it would if turned by a heavier fish; and the slender rod bobs, not indeed with the steady curve that tells of a big one, but sufficiently to suggest a pounder. To bring such a bass to the net is child's work. In vain it eddies and circles round the stern. The little bronze reel is wound in almost without a hitch, and at just the right moment Cox has shipped his oars and dipped the landing net under a gleaming little bass of perhaps a pound and a half. One does not fetch out the steelyard to these small fry, though such a fish is as pretty and as sporting as any of its size. Trout, someone murmurs? Speak up ; and remember that, though we use a trout-rod, the cast is of salmon-gut, for to trust to anything finer would be to run needless risk with that record fish of the season, to dream of which means inexpensive bliss. Hook a bass like him that lies shining in the boat, quieted with the merciful tap of a rowlock, on a moorland trout cast. Hook him, if you like, but play him in a bath if you want him, for he would break your gossamer gut for all your arts. Another sand-eél on the hook, and once more we turn our back on Cox, who again dips the paddles gently in the stream. Three or four more bass, a little smaller than the first, are hooked during the next half hour. And now the salt water is flooding the estuary in earnest ; the boat drifts yards upstream 
each time Cox drops the sculls for the landing net; and away now to the rough ground, just below the bridge, where, undisturbed by the salmon-nets, the big bass lie in wait for the shoals of brit that come, reckless of their doom, on the rising tide.

The sun is well up over Bitton now, its rays, which make themselves felt, lighting up the picturesque hamlet of Shaldon, which sends stray wreaths of smoke curling up against the green background of hill beside which it nestles. An early bicycle glides across the bridge, but the majority of folks rise late in the West, for where Nature is loveliest, there man is least ambitious.

As we pass the topmost ships, with only a couple of yachts between us and the bridge, the dripping bait-box is hauled inside the boat, and the largest sand-eels are picked out from the wriggling mass, for big bass like big fare, and if the giants are to be tempted, we must offer them the best we have. Instead of trailing the baits, as I did for the smaller game below, I now pay it out, little by little, an inch or two of line being pulled off the reel at the time. This I go on doing mechanically, while Cox just dips the paddles so as to keep the boat back ever so little, that the line may run out straight as a wire. Past the tennis-courts we go, looking through the arches of the bridge at the purple line of the tors on Dartmoor, and now the 
baits must be thirty yards away from us. There is a slight check, the merest irregularity, which would not be noticed by anyone new to the game, but which we know so well that instinctively the left hand tightens on the butt, while the right hovers about the reel. There it is! Down goes the top, no bobbing this time, but a deliberate curve to the water's edge. Murder! screams the winch, no half-hearted burr of the check, like that evoked by the little fish below, but a sustained crescendo note, while the line grows so rapidly less on the spinning axle that it looks as if the fish is going tobreak me. Once, and only once, thank goodness, that did actually befall me on this spot. What manner of fish it may have been, I cannot, without having got a glimpse of it, positively say. Local opinion favoured a salmon, but more probably it was a monster "cobbler" bass. It simply took the bait down by the lowest buoys, opposite the cricket-ground, started away at lightning speed, and, as the song says, " never stopped running till it got home." It ran two yards of gut and one hundred yards of line to their full limit without a pause and then, without apparent effort, went on, fortunately breaking the line so. near the hook that my loss of tackle was small. Other bass I have lost in that stream, but that is. the first and last of any size that fought invisible. The fish that I have hooked here by the buoy, 
though a powerful fighter is not an adversary of such extreme mettle, for already he has halted in his mad career, a respite of which advantage is taken to reel in half a dozen yards. Steady there! A fish of such size must be wound in gingerly, with caution, and the hand must be ever on and off the winch, winding only when the fish is so minded, since at this early stage of the struggle a direct clash of wills would mean disaster. Away goes the bass again, with strength renewed by its brief rest. Its yielding was but a feint, and this time it runs out twice as much line as I reeled in, and so is further from the boat than ever. Another halt, another reeling in ; and now we are nearly up to the bridge, for all the time the boat has drifted along. For a moment I am undecided whether to shoot through the middle arch and kill the fish above the bridge, but that means losing time, so " This side, Cox!" I say ; and Cox understands, with the knowledge born of many such encounters, that he is to back the boat into the shallows on the railway side. It is there, under the windows of the early train, that the last stand is made. Gallantly the bass disputes every yard, for he is fighting for his last chance now, and he knows it. Gradually, and with fewer interruptions, I get the fine line back on the reel, and now his green head can be seen on the surface, shaking the worrying hook, as a terrier shakes a rat, and 
now and then making a futile attempt at retreat. In vain, such tactics! The line is tested, the hook tempered; and at last, with a final protest that spins the reel for twenty revolutions, the fish rolls on his side and the ready landing-net is beneath it, the handle straining with the weight as Cox lifts what looks like a good ten-pounder over the side. A powerful fish, even out of the water ; and the head has to be gripped firmly between the

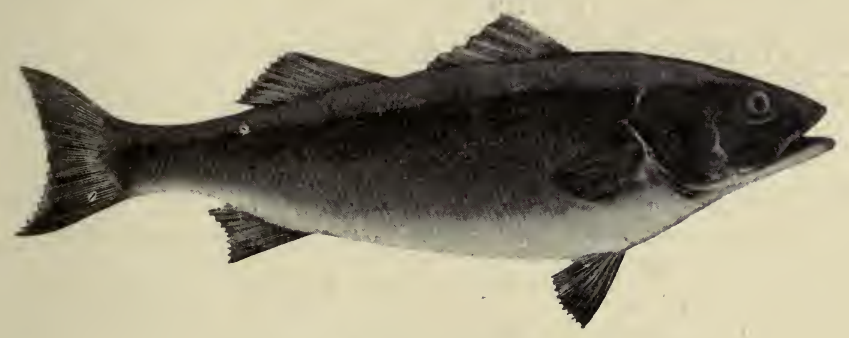

A WELL-GROWN BASS OF $11 \frac{1}{4}$ LBS.

knees while the hook is taken out of the angle of the jaw, and the steelyard, confirmed later when we got ashore, registers eleven-and-a-quarter pounds, a noble fish and the best I ever took on the rod in that river. The better part of half an hour went to the playing of him, and, with such a trophy in the boat, we have had enough for the moment. It is improbable that I shall ever beat it; it is almost certain that any other fish, which I may catch by staying out, will be a sad come-down from such a beauty, so I decide to 
go back in time for a dip from the pier head before breakfast. Other boats are out now, half a dozen of them ; and the charm of the earlier solitude is gone. Thirty inches that bass measured when we got him against the tape, and for the last three years he has reposed in a glass case along with a brother in misfortune, his inferior by a couple of pounds, which I had caught with the same hook the morning before. The hook is enshrined with them of which it was the undoing.

Mornings like this, and evenings too, with smaller game to my score, I must have spent a couple of hundred, most of the mornings in the congenial company of G. H. J., who, ever in demand as a healer of the sick, was debarred from fishing the later tides. The evenings are as the mornings, only the folk that lie abed for sunrise are awake at sunset, and we get much of the society that we do not yearn for. Glancing at the actual diaries that have inspired this reminiscence, I find that in the two summers of 1902 and 1904my fishing in 1903 was continually interrupted by a tour, which I made of all the fishery ports of England and Wales-my total catch of sizeable bass (not reckoning the small fry) amounted to 29 in the former and 49 in the latter year. This reads like a small total when one concentrates attention on one fish, but it must in fairness be remembered that fishing was done only in the 
intervals of hard work, for a couple of hours in the mornings every other week (spring tides) of summer and an hour or so of an evening. There were no very large fish, the best being the brace already mentioned (July 10 and 11, 1902), one of $10 \frac{1}{4} \mathrm{lbs}$. (July 20, 1904), one of $8 \frac{1}{2} \mathrm{lbs}$. (Aug. 5, 1904), and several of $6,5 \frac{1}{4}$ and $4 \frac{1}{2} \mathrm{lbs}$. in both years.

Many and varied are the memories of those days with bass in the Teign. I see again some friends, who fished there with me: Cyril Maude, not acting a part now, but in deadly earnest as he hooks and kills a four pounder the very first time we are out, and within a few minutes of starting. " John Bickerdyke," fishing very craftily, trying new dodges, essaying double flights, discussing the conditions, expounding the theory, and never far behind with the practice. That fine July dawn in 1903 was the first time he and I had fished together since, at Cowes some years ago, we made a brief and unprofitable raid on a famous ground for pout, but were euchred by a tide that ripped through the Solent at a pace that worried even the pulsing leviathan that set us gaily dancing in her wash as she pointed her nose down Channel. "Frederick the Grocer," the Southampton watermen call her, and, though the hospitality of the Prince of Wales Pier has lured many of the great German liners to Dover, the "Grocer" remains loyal to the Solent port. 
The Teign is a noted salmon river, and now and again (rarely again!) a good fish is taken on the rod as high as Bridford. Sometimes, in the fall of the year, the river is so low that salmon get imprisoned in shallows below the falls, where they

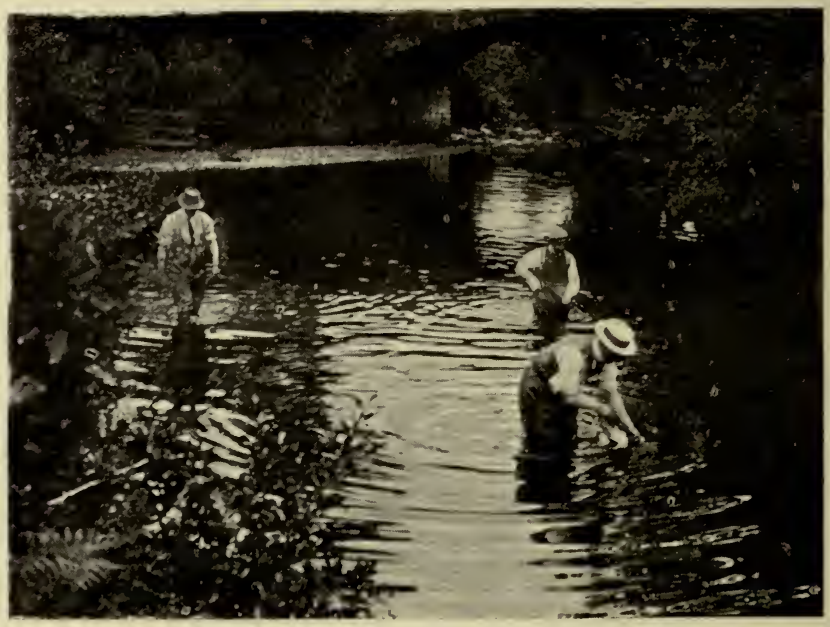

NETTING SALMON IN THE UPPER TEIGN

lie at the mercy of poaching larm labourers, and now and then we used to net them out in landingnets and transfer them at once, running across an intervening meadow, to a higher reach where they would be immune from the hayfork. The refusal of one of the riparian owners, a farmer, to permit this salvage on the part of the Association last 
year was an unconcealed admission that he preferred the fish to remain accessible.. Such a case should engage the attention of the energetic Salmon and Trout Association.

Of the many difficulties that hampered me in the capture of some bass duly brought to the net, I came out by luck rather than of set purpose, yet one or two of these episodes of narrow shaves have some practical interest. On one occasion, which I shall never forget, a heavy bass contrived to double round the submerged chain of a floating buoy. Naturally, that fish was given up for lost, and it was rather with the idea of recovering what remained of the gut than in any hope of still geting on terms with the fish that I bade Cox row the boat round in the same direction, so as to unwind the line. Great was our surprise to find the fish still on-it says something for the six feet of gut to have stood the strain-and still greater our delight when it headed full speed upstream, for out in the deep channel of the river it was doomed. It is strange how often the instinct of self preservation seems suddenly to desert a wild creature and leave it at the mercy of circumstances. Here was a fish with cunning enough to double once round the chain, thereby taking the pull of the rod off its mouth; yet it never occurred to it either to wrench itself free, or, being pursued, to double again and thereby to baffle me $14-(2272)$ 
once more. No ; it preferred to throw its cautious tactics to the winds and to fight to a finish-there could be only one with such tackle-in open water.

Next morning, a still heavier fish was hooked closer to the bridge and was played almost to exhaustion. Yet it looked as if at the eleventh hour fate were going to intercede, for a great clump of weed, which could not by any possibility pass the top ring of the rod, seemed to be stuck fast on the line about fifteen or twenty feet above the fish. What was to be done? To handline so heavy a bass, even one to all appearance tired of life, on gear so light would be a highly dangerous alternative. In despair I told Cox to run the boat on the bank, intending, if the weed did not shift, to retreat from the waterside until the fish was brought within reach of the net. Yet the fish itself saved the situation, for, before I had time to carry this plan into execution, it made a final desperate effort to shake out the hook and in so doing loosened the hold of the weed, which, to my great relief and the final undoing of the bass, went sliding down the line and thus enabled me to reel the fish up to the side of the boat.

Weed is the great nuisance at Teignmouth, as indeed in most estuaries where there are salmon nets through the summer to tear it from the bottom and leave it piled high and dry in the sun for the next rising tide to float upstream. There 
are even days down there when we give the weed best at starting, seeing how matters stand and determining not to waste good bait under conditions which almost certainly preclude all hope of success, for the bass will not touch a bait with the least shred of weed attached to it. This makes it a particularly serious handicap, for the fisherman, waiting in vain for a bite, is tempted to put the lack of fish down to the weed, whereupon he reels in, thereby often, no doubt, by dragging it against the tide, impaling weed on a hook that was innocent of it before he wound in his line. For those who fish for pleasure, life can hold no joy if they have to reel in thirty or forty yards of wet line every few minutes and remove clinging weed from the bait. The better part, therefore, is to go home and dream of better days to come, for now and then, particularly on Monday mornings, when the salmon nets have lain idle during their compulsory weekly close time, there are occasions when this herbage ceases from troubling. For the lurid language with which some men greet this passive vegetable every time a frond drifts past the boat there can be no excuse whatever.

Another nuisance, pressing, undeniable, is the number of other boats sometimes out on the same errand. To some extent this too generous measure of the company of your fellow creatures may be evaded by very early attendance. . Yet if only all 
the boats would play the game, drifting in line from the buoys to the bridge, then dropping back in the shallows till abreast of the lower buoy and again bringing up the rear of the procession, the whole moving round like the tyre of a wheel, why, double the number could fish without one disturbing another. But to play the game is the last thought with some of the boatmen. The fault is theirs, not that of the visitors, who know nothing of the conditions and therefore place them unreservedly in the hands of the man who rows the boat. This individual knows as a rule more about the inside of taprooms than of the manners of bass. Backwards and forwards he rows, across the river, downstream, trailing the bait against a choking tide. These short cuts to glory lead, like some others, to bankruptcy, for they get foul of other lines, and those who have been fishing in the proper way sometimes find themselves compelled to use a knife rather than waste too much time in unravelling knots. In the circumstances, they have not the heart to cut their own line.

Now it is obvious that the human nuisance cannot be treated quite on all fours with the vegetable one. Weed comes under the head of those " acts of God," against which even insurance agents, who, in their infinite desire to oblige, cover earthly risk and most heavenly ones, make no provision. When therefore weed gets across 
your line, the only way, if it persists, is to go home and develop an interest in parish pump politics or foreign wars, anything in fact but bass, until

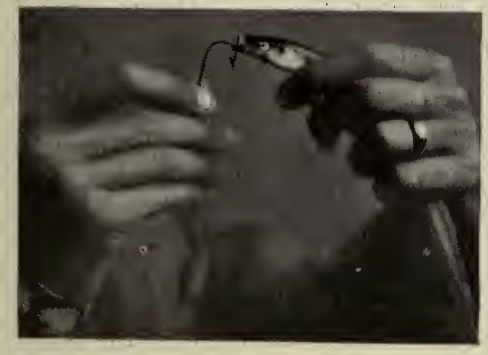

1

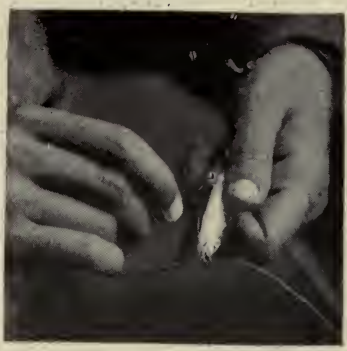

2

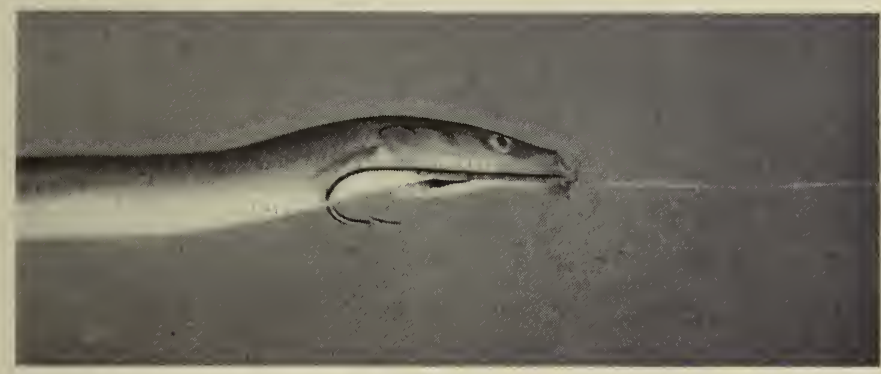

3

BAITING WITH SAND-EEL

another tide has washed the estuary out and perchance driven away the plague. When, however, it is by another man's line that your own is fouled, and in circumstances that leave you in no doubt whatever that fault was entirely his or 
his boatman's, then, if there are no ladies on the river at the time, it is desirable to offer very frank explanation of your opinion. If the man is a visitor, ignorant of local usage, see him ashore and point out to him that his man, knowing nothing of bass fishing, is taking his money under false pretences, and recommend him to one who will fish less jealously and with more result. With the boatman, if he raises objections, let your argument be quite brief and to the point, only, if there should be a sudden appeal to more primitive logic, make quite sure of being the first to reach the point of the chin.

Since this retrospect of bassing in the Teign has, somewhat more than the rest of the book, assumed the didactic form, frankness compels the admission of a third handicap, the frequent difficulty of procuring live bait. Sand-eels, the only lure for bass in that river, are usually abundant throughout the summer months in the sand banks, but they take catching. A few may be raked, preferably on the night ebb tide, with a good deal of exertion, but this exhausting and sleep-robbing work is not popular, and, even if successful, the raking injures the delicate little creatures and does them no good as bait. For this reason, the ground-seines are the best source of supply, but they are not always worked. Some of those who work them claim the birthright of starving in 
idleness. If they can catch a philanthropist nodding on the bench beside the lighthouse, they will grumble to him as long as he has a mind to listen, but they-sometimes decline to work the nets for days together. Their reasons are various. Sometimes the fish are too few to make the resulting harvest worth splitting up in so many shares. At others, there are too many to keep up the price, since the "sprats," as they call them, do not sell outside the town. They therefore loaf on shore, the nets lie unused on the sand, and the angler kicks his heels at home for want of bait. Unfortunately, there is no substitute. Out in the dancing waters by the Ness, it is true, rubber baits, trailed slowly after the boats, and kept clear of the snares and pitfalls of the weed and mussels, catch numerous small bass of the size to amuse the casual visitor, but also to leave the regular fisherman unmoved. The heavy fish within the river despise such indifferent imitations, though at Margate and one or two other places I understand that artificial baits are successful with even large bass in the open water. In the Teign, it is living sand-eels or nothing. Not even launce, a related fish of greener tint, will tempt the " cobblers," and the amateur is wholly dependent on the netsmen, unless his man will rake a few, an exhausting office, which inspires in him no enthusiasm. Now and again, in despair at seeing several 
good tides go by without bait from the ordinary source of supply; three or four enthusiasts subscribe ten or twelve shillings, and such inducement is sufficient to induce the men to shoot a seine. The men employed by the subscribers then divide the catch and stow it away in their baitboxes, from which most of it is as often as not purloined the same night by others, who regard simple purchase as a ridiculous manner of acquiring property. It is almost to be regretted that the good old times are gone, when a man who stole fishing tackle paid the death penalty, while the punishment for removing fish from the kettlenets on the Kentish coast was a night in the " tippe house," followed by several hours next morning in the stocks, during which the whole village, armed with every unsavory missile that devilish ingenuity could devise, made a target of the thief's face. If justice were still done in the land, I know one or two in Devon, who would keep the stocks warm.

The bass is a fish chiefly of estuaries. Both it and the grey mullet are taken in the beautiful if narrow outlet of the Lyn, which rushes to the Bristol Channel between banks that recall some scene of far-off Switzerland.

The grey mullet is a fish of very different appetite from the bass. In some other habits the two are not dissimilar, for both are of a migratory 
disposition, both are most in evidence on our coast in the warmer months, both come from southern latitudes, and both are found in docks and estuaries and alongside piers and quays. In their feeding arrangements, however, two fishes could

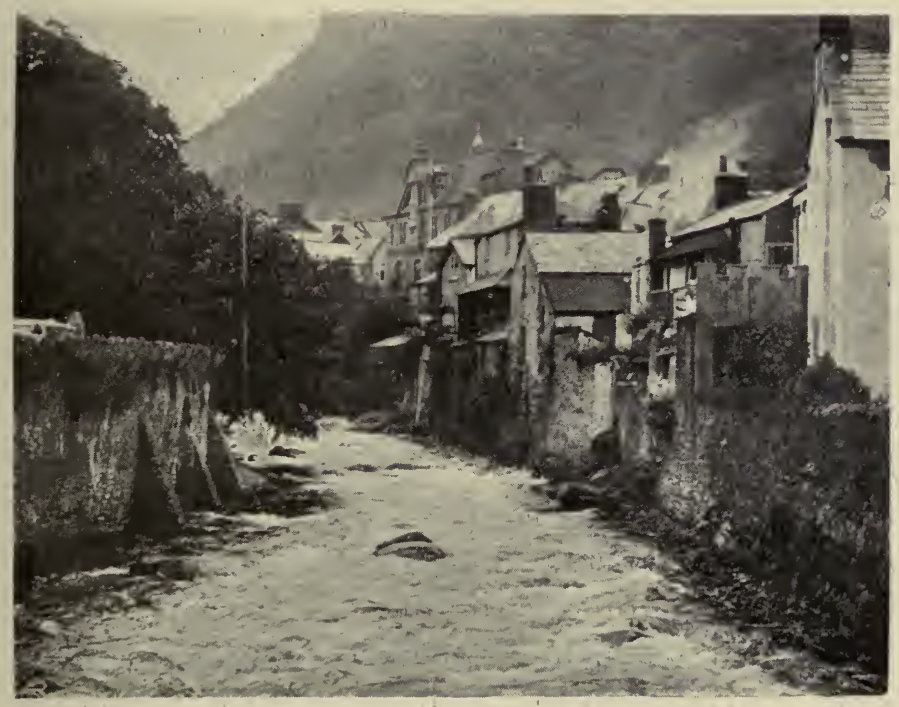

WHERE THE LYN NEARS THE SEA

hardly differ more, for the bass is a dashing hunter of smaller fry, while the grey mullet is a soft, grubbing feeder, more like a roach. Experts, who have made a study of its habits at Margate and elsewhere, say that it shows an exclusive taste for soft food, whether this be the vegetable 
and other refuse thrown off a pier, or the minute wormlike creatures that live in the soft submarine soil known in some parts as "ross." It is one of the most uncertain and capricious of sea-fish, and, as the result of the brief encounter which I am about to relate, I should be inclined to regard the bass as Esau to the mullet's Jacob.

How I sought mullet at Littlehampton and caught them at Leghorn, off Mogador, anywhere almost except in England, has been related. The manner in which this elusive fish beat me in home waters until the present year was remarkable. For a long time, particularly since the Devon bass and a miscellany down in Cornwall offered annual solace, such repeated failure did not worry me, and I tacitly gave the mullet best. One night, however, I took the chair at a meeting of the British Sea Anglers' Society, at which Mr. T. W. Gomm, undoubtedly the most scientific and successful mullet fisherman on its list of members, read a paper on the subject. That ruined my peace of mind once and for all, and I fidgetted over those Margate mullet until a few weeks ago, when, during the third week of June, he begged me to visit him at that town and catch a mullet. It seemed too good to be true, for many attempts had hitherto resulted in as many failures, but I gladly accepted and went down on the day that rain drew the second Australian match at Lord's. 
For once luck came my way, and, although but four mullet had so far been taken during the season (which opens with almost monotonous regularity after the 10th June), I contrived to catch two, one just topping $3 \mathrm{lbs}$., the other somewhat smaller, on the first day of trying. The total bag to three rods that day was seven fish weighing just over 20 lbs., so that, even on averages, my contribution was, for the novice of the party, not wholly to be despised. The other members of the party were Mr. Gomm himself and Mr. Francis Daunou, whose enthusiasm for mullet fishing is a veritable passion at white heat, for surely no lovelorn poet was ever more attached to his fair mistress than Daunou to his mullet, and certainly both Gomm and he exhibit extraordinary skill in the systematic capture of that difficult fish. Their manner of taking it beneath Margate Jetty is best compared to roach-fishing in running water, and indeed the explanation is simple, for Gomm was previously a very experienced Thames fisherman, having learnt most that there is to know of the fishes of that river, from the Thames Trout downwards. To Margate Jetty he introduced the methods acquired at Sunbury and Staines. With what admirable results this marriage of sea-and river- angling has been celebrated may be seen from a glance at their fishing records, from which it appears that Daunou's best fish 
weighed 8 lbs. 7 ozs., while Gomm followed with a good second at 8 lbs. 4 ozs., and their highest number in one day's fishing was thirty-three.

I will briefly describe a day's mullet fishing in company of these experts; who, like the sportsmen they are; make no difficulty about imparting their methods. Nor is their own sport likely to suffer by such frankness, seeing that anything like consistent success would call for immense patience and no.little skill. Moreover, groundbait plays, as will presently be seen, a most important part in the result, and the additional groundbait used by new recruits.would undoubtedly attract, and keep, more fish under the Jetty.

A little before five on a brilliant, if somewhat breezy June morning we walk down to the harbour with rods and tackle and a cloth full of sweet, newly-squeezed bread paste, and are met at the Jetty by Bob Ladd, most excellent of boatmen, who has in one hand a pail of soaked bread and in the other a great bag of bran and barley meal. The boat is run down the slip on wheels, and, as the tide is half way out, we embark from the soft " ross," which conceals the food of the mullet. It is but a few strokes to the Jetty Extension, and there the boat is very carefully moored fore and aft, so that we have a clear run of water in the Cliftonville direction, over which the ebb tide will carry the 
floats. When the tide turns on the flood, or, to be accurate, a little later, the position of the boat is changed, and it is then moored between two posts opposite; so that the current, now making towards Westgate, carries the floats in the contrary direction over the same swim. As soon as the moorings are fast, Bob sets solemnly to work kneading the ground-bait in great balls, as used by anglers on inland waters, and the rest of the party put their tackle together. The rods are ten feet long and of hollow cane, fitted moreover with large rings, so that the fine silk line (which has previously been treated with boiled vaseline) may run without hitch. The reels are of medium diameter, wooden and Nottingham pattern. These mulletdoctors never use the check, whether from the fear of frightening the sensitive fish or not was not explained. A slider-float is used, and a small rubber band prevents it from running too far up the line. The hook is a number 3 Crystal, and two or three small leads are pinched on the gut immediately above it, just sufficient to cock the float.

The ground bait is now ready, and a large ball is dropped in front of each angler, who, having carefully plumbed the depth and adjusted his float so that the hook swims three or four inches from the bottom, baits it with paste and sets his float adrift on its first swim. 
206 THE SALT OF MY LIFE

And now we are all busy, letting the float travel nearly as far as the opposite post, then bringing it back to travel over the same ground again. This usually means losing the paste, so that the rebaiting is a considerable item in our activity,

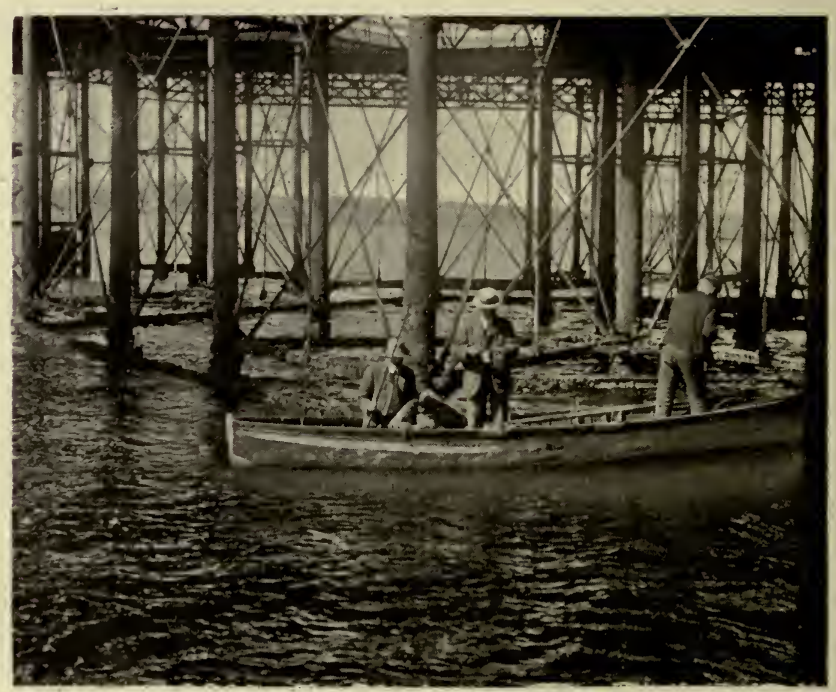

MULLET FISHING UNDER MARGATE JETTY

and indeed on this first morning there is so much rebaiting for the first hour or so that I begin to fear that my customary luck has followed me to Margate, and that I am not even going to see any of the coveted mullet caught by others. Suddenly, however, the expert wrist on my right gives a 
flick, and " In him! " cries Gomm, whose cane rod is bending madly to right and left, as a fat mullet, evidently a good fish, tries in vain to plunge towards the piles. The other lines are brought in, so that the landing net may have a fair field, and in a very few minutes a splendid mullet of $4 \mathrm{lbs}$. $14 \mathrm{ozs}$. is kicking in the linen bag provided for its reception. An hour later the rod on my left is behaving likewise, and a second fish, half the weight of the first, is added to the inside of the bag. The rod straight before me refuses to bend. Several times I think I see a bite betrayed by the green-and-white tell-tale, but it is long since I did much float-fishing, and my striking is ill-timed. And now, after two hours of it, the tide first falls slack for a little and then preceptibly drains towards, instead of away from, the boat. Properly speaking, we ought to change over and fish the up tide facing west, but it is windy in that quarter and, anxious to get the benefit of lee water as long as possible, we continue fishing, without further result until it runs too strongly to be fishable that way. The new position is then occupied; the remainder of the groundbait is thrown overboard; and no more fish are caught at all, though I just manage to turn one, striking a fraction of a second late, and feel the weight of him on my rod. So far, I stood with the mullet as before, though I had at any rate seen a couple caught in the same 
boat, which was a step in the direction of a more intimate acquaintance. All that day the wind blew hard from the south-west, and little "white horses" galloped across the water, much to my host's disgust, for such cavalry, he declared, was a menace to our sport in the afternoon. It was not therefore in any very sanguine frame of mind that we returned to our boat at four in the afternoon, a couple of hours before low water, and once more took up the correct position for fishing the down-tide. Again, the rods were put together, and the ground-bait was flung as a sop to the mullet. In future, I think I shall always tempt the Fates to be kind by sallying forth with the conviction of failure, for in the midst of my despondency at having to record yet another misfire, down went the float and I too enjoyed the sensation of a good mullet careering in an arc with as wide a circumference as I dare allow so near the ironwork. Even then they assured me that the fish was not yet caught, as mullet very often, and sometimes unaccountably, break away at the last moment. But luck was mine this time, and a fish of a shade over three pounds, a beautiful, fighting silvery mullet, lay gasping in the landingnet. Such is the importance assumed by a fish that has hitherto baffled all one's efforts, that I doubt whether any man ever thrilled more over his first salmon than did I when at last the net 
was safely under my first English mullet. It broke ice that had grown too thick with time, and even if I had not caught a second, this time on the up-tide, I should have been perfectly satisfied with the result of the expedition.

Ground-bait, then, with tackle as fine as can be trusted, is one secret of success with grey mullet, and how important the ground-bait is may be gathered from the conviction of these Margate experts, that the regular return of the mullet to the water beneath that Extension year after year, and, what is more, their loyalty to those haunts throughout the summer and greater part of the autumn, must be entirely attributable to the great quantity of scrapings and refuse thrown over each day from the restaurant upstairs. Of green peas, for instance, this singular fish is inordinately fond, and the paunch of many a mullet is found to be crammed with that vegetable. Bran is another weakness, and mullet will even wander around and suck it in, a particle at a time, until fat with it.

Yet above the matter of tackle and bait I should personally feel inclined to set the value of close study by regular anglers. If you can place yourself, as I had the good fortune to, under the guidance of residents who have fished under every kind of conditions and over a period of years, success is, if not assured, at any rate very probable. My memories of those Margate mullet are most $15-2272$ ) 
agreeable in all but one particular. It has pleased those who cater for the week-end public to run large steamers between these Kentish resorts and the metropolis, with the result that on Sundays at any rate a very fearful collection of semihuman wildfowl is diffused among the coast towns for several hours, massing on the piers and jetties towards the hour of return. A few score of these filthy ruffians gathered on the upper deck of the Extension immediately over our heads, on one occasion and went from unnoticed chaff to more aggressive measures of annoyance. Cigarette ends were the first missiles, and it would have been well had they stayed at these, but unfortunately there is a species of human beast that cannot find itself immediately over the heads of its more respectable fellow-creatures without resorting to a disgusting act, in which the marksmanship of the llama and archer-fish is emulated if not surpassed. The spitting hooligan is so base a coward that he rarely indulges in his beastiality if there is the smallest chance of reprisal, but it will easily be understood that the occupants of a boat moored at some distance from any landing steps are peculiarly helpless. I would suggest to the authorities on the Jetty Extension at Margate that, as other pier companies find anglers worth encouraging, and do what is possible to ensure their comfort, it might be worth their while to make a nominal 
charge (say, the equivalent of the admission money) for boats moored to the piles and see to it that fishermen are not exposed to such disgustng treatment from above. It would even be right for them to take such steps without any such charge, for the continuous success, year after year, of the few habitués unquestionably attracts others to the Extension itself, some to try their hand from the stages, others to watch the more experienced anglers in their boats. One of the Jetty officials might easily patrol the very small square of deck, from which such expectoration has any chance of being effective, and the sooner orders are given to this effect, the better it will be for the reputation of a very delightful resort, which such practices have long discredited with many who might otherwise patronise it.

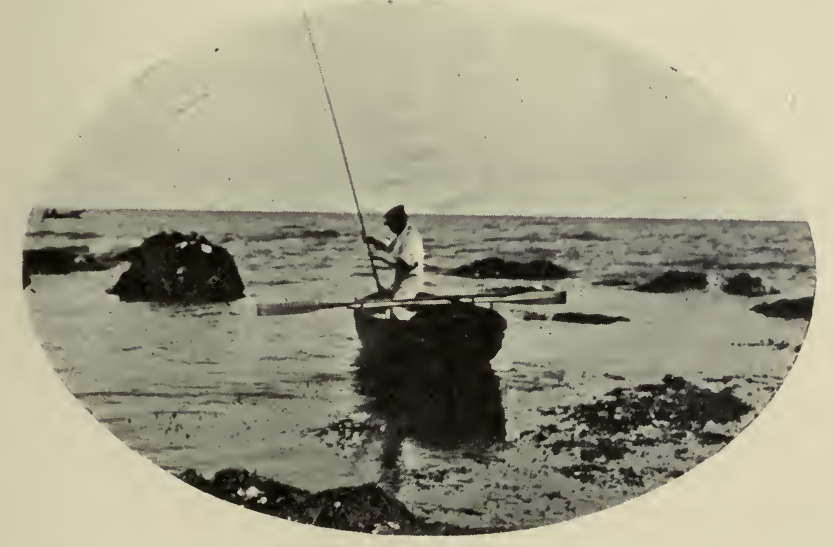




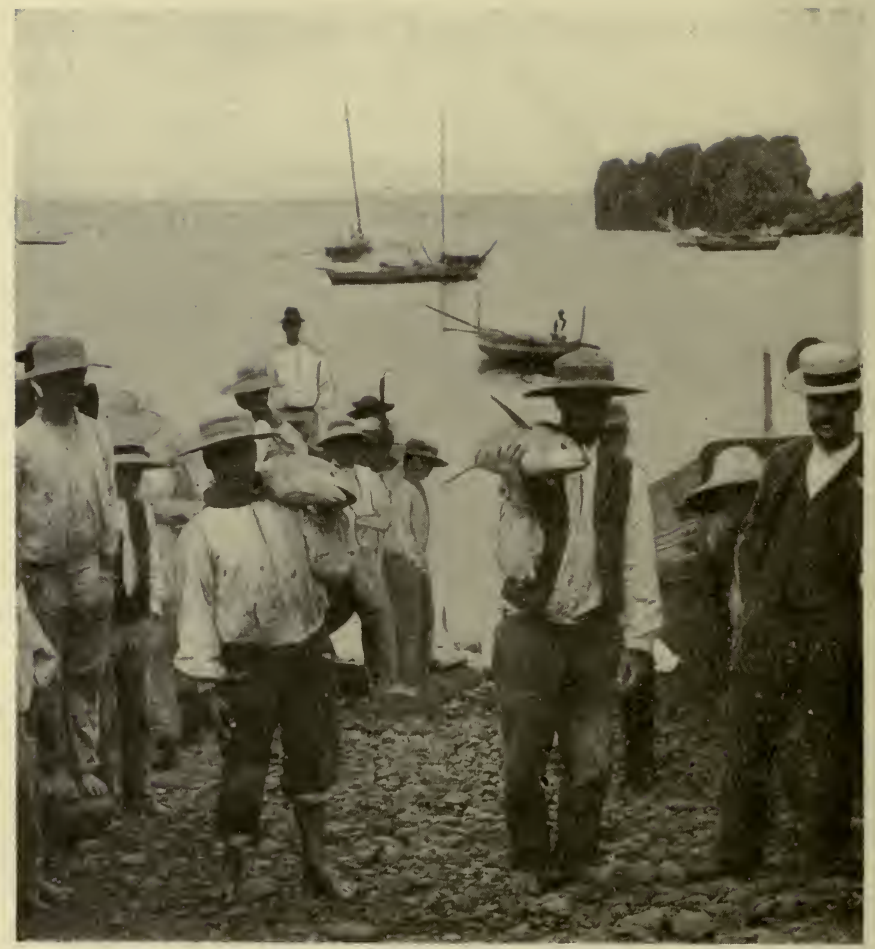

Photo

Perestrillo

BRINGING SMALL TUNNY $\Lambda$ HORE 


\section{A FORLORN QUEST AND SOME COMPENSATIONS}





\section{VIII}

\section{A FORLORN QUEST AND SOME COMPENSATIONS}

Success and Failure-Welsh Adders-Other Failures : Arun and Teign Mullet-Poole Bass-Bexhill Cod-Lulworth Pollack-Eddystone Whiting-Sydney Grouper-Queensland Perch-Maldon Brill-The Worst Failure of all: Madeira Tunny-Origin of Plan to Catch them on the Rod-Preparations and Arrangements for the Trip-Arrival at FunchalOur First Outing-We catch a Turtle, but no Tunny-Our Second Failure-We Follow the Tunny to Porto SantoCamp three nights on the Ilheo de Cima with C. B. CossartFishing in the Rock-pools-Barbary Type of Our FishermenBringing Spiders Home for the Zoo-We Catch a Variety of Fish in Trammels-Other Rod-fishing: Sargo-fishing at Sunset-Novel Way of Getting Crab-bait-The Birds of our Island-Padre Schmitz-Trailing for Garoupa-A Last Try for Tunny-A Rough Sea for Fishing-Chances of Catching Madeira Tunny on the Rod-Different Classes of TunnyDifficulties-Mr. Holder's Advice-Fishing for Mackerel and Muræna at Funchal-Torches and Groundbait-An Incantation-Farewell to Madeira !

OF failures it is the lot of the fisherman to taste more generous measure than of successes. Fortunately, the memory of success stands the wear and tear of time much the better of the two, else suicide would be more popular. This is so with trifles as with life's greater traffic. Those two 
Teign bass, caught on successive mornings, are before me still; every incident of their capture, from the first dip of the rod to the final work of the gaff and the glorious weighing, that went even beyond expectations. It is only with an effort that memory conjures up the many lean days, the days on which we hoped against hope, when the sea was too rough, the river full of weed, when the storm came up so rapidly from behind the hills that the zenith of the day was Egyptian darkness, when hooks betrayed the trust reposed in them, when fish were both loved and lost, when fish could not be even lost, since they would not take the hook. Such rank and file of failures is consigned to the limbo of oblivion.

Here and there, of course, some prodigious fiasco stands out undeniable from the background of the life that is lived and done with. Not all of fishing, but also of other minor hobbies, has failure made great part.

There were those Welsh adders! Where the merry Monnow frets with fitful music over the stony lairs of trout and grayling, I three days in succession sought the elusive adder, even towards the peaks of grim Garway and exhausting Graig. Sought the reptile, and found not ; yet the expedition, barren of results, was not without interest, since it revealed the methods and enthusiasm (which is more precious than method) of one who 


\section{A FORLORN QUEST, ETC.}

has since published important works on our snakes and lizards.

Dr. Gerald Leighton, with whom I had long enjoyed that postal acquaintance which often exists between men interested in natural history, invited me to visit him at Grosmont, near Hereford, where he then had a practice. I accepted with pleasure and spent many agreeable hours dissecting adders and discussing their life story, and above all the one problem more fascinating than the rest, in his surgery, the walls of which were lined with every stage of adder in picklejars, material for the forthcoming book. To the pleasure of reading his letters about scrambles in and out of quarries, firing gorse, digging out mole-runs, kills and escapes, I now added the joy of toiling in his tracks for three blazing days of June, the thermometer at $95^{\circ}$ in the sun, the soil brick-hard after a drought that had already lasted three weeks. We plodded all over the beautiful Kentchurch estate, crashing through larch woods and glissading down red rocks. Every likely ingle was examined, every clump of bracken disturbed, every pile of timber prodded till not so much as an ant could lie hidden. With all this zeal, we got no adders. The odds against lighting on a particular reptile anywhere in six or eight thousand acres are heavy if you are looking for it. Had a little child gone forth barefooted, it 
would in all probability have found an adder within a few hundred yards of the garden gate. Once indeed ten inches of a bright-hued female vanished over a low boulder and under a bush. We fired the bush, but it was a case of

"She wandered down the mountain side," and we saw no further trace of her, but were hard at work for twenty minutes putting out the conflagration.

More profitable, and much less tiring, were our rambles in the surgery. One adder of $24 \frac{3}{4}$ inches, which we dissected, had slain a bullock only the week before and was found close to its victim. It was a female, and contained seven well-developed embryos. From a larger specimen Leighton had once taken seventeen, but never more. One authority gave the number as ranging up to forty ! That, if true, would in itself settle, once and for a!l, the vexed question of the female swallowing the young to get them out of harm's way, for, by the simple process of dilating the æsophagus with a blowpipe, we satisfied ourselves that that waiting room might have accommodation for seventeen, but that never could room be found inside it for forty.

That district of South Wales, where Leighton accumulated material for his book, is particularly favourable to the adder, for the hillsides are sparsely populated by human beings, besides 
affording ample food and cover. As a result of conditions so auspicious, adders not only abound in Monmouthshire, but also attain to the largest size recorded in these islands.

It will take long for memory to lose the picture of those beautiful Welsh hills, the distant views, the crisp air, the scent of new-mown hay, the palefaced Hereford cattle staring meekly from every byre. Above all, the vision of Leighton standing at attention with a fearful trident poised to strike, while with his boot he carefully turned over some likely looking stone. From the valley beneath came the sobbing of the Monnow, deliciously cool as it fell on our burnt up senses. If one personality besides Leighton's stands out from that panorama, it is that of a prehistoric lizard of a man, a pterodactyl in fustian, who stood aloft on a haycart, brandishing a fork just above my jugular, and prayed that that rustic tool might fall from his hand if he did not tell the truth when he swore to having seen an adder swallow her entire family.

Of fishing failures, have not more than a few been already admitted to these pages? The Littlehampton mullet were of these. There were other apocryphal mullet in a little lagoon fed by the Teign, beside which a gallant Indian colonel and myself sweltered through a hot August day, when we might as well have hoped to catch a 
pelican. He recalled strange Pathan oaths, acquired no doubt in earlier days from those whom he had hanged after they had sniped in vain; I lisped sentiments, not less fervent, in a readier tongue. There were the bass of Poole, bass of enormous size, which one August night I sought with lively prawns in a downpour of rain, that drove me back to the hospitality of the "Antelope." Were there not also the heavy cod of Bexhill, the fighting pollack of Lulworth, the abundant whiting of the Eddystone? All of these were failures on the occasions that I have, black on white, before me. In pursuit of the cod I spent futile days at the then undeveloped Sussex resort; for the pollack I put in a whole week in the beautiful cove and around Durdle Door; the whiting cost me a night's rest and the hire of a smack. To my own rod the total bag in these three expeditions was: cod, none; pollack over $5 \mathrm{lbs}$., none; whiting, five. When I sought to explain the Bexhill failure, I failed ; but at Lulworth want of bait, and at the Eddystone excess of tide were the causes of our distress. The Sydney grouper, the Tasmanian trumpeter, the Queensland perch, all among the fish that failed, were noticed in their right place.

The Maldon " brill," failure was rather amusing, or so at any rate I am able to consider it after the lapse of years, though at the time the humour of 
the situation did not appeal. One who resided in the quaint and picturesque Essex town told me that if I fished the Blackwater in winter on the evening tide, I should almost certainly catch brill. To catch brill in a river, even in a tidal reach of it, promised sufficient novelty to make the expedition worth a trial. I therefore arranged by wire for Handley's yacht to be at my disposal, and it was with the keen anticipation that casts a halo over all such preliminaries of a novel angling quest that I stepped into my train at Liverpool Street one cold and clear November morning. Thanks to carefully acquired wrong information, I had chosen the wrong week for the tides, with the pleasing result that, on a bitter evening, I had the satisfaction of kicking my heels on a frost-spangled deck, for three hours before the ebb tide slacked sufficiently for the leads to hold the bottom. We were anchored over an agreeable spot known as Death Crick Hole, such a scene as the genius of Mr. Baring Gould or Mr. Blyth would revel in for some dreadful deed of marshman's violence. Every few minutes, new flats of ooze were uncovered in the silvery light of the moon, before whose cold disc there passed a strange and ghostly squadron of night fowl, herons, dotterel, dunlin, teal and mallard. No sooner had the tide done ebbing than it apparently started to flow back with little less vigour, but in the brief interval I was so 
lucky as to catch the one fish of the evening, a whiting-pout of perhaps three ounces, which had cost me, all told, about fifty shillings. In one respect, however, this solitary and sorry trophy was worth the money, for it solved finally the mystery of the brill. The local name for this fish of many aliases is, it transpired, "whitingwill," abbreviated by the sanction of usage to "will," and this it was that had moved my informant to put me unintentionally on the track of a fish that never was seen in Maldon outside of the fishmonger's. This highly successful adventure had an appropriate sequel in a dreadful walk by lantern light over endless mud flats, and so, through the sleeping town, to my refuge at the "Ship."

This preliminary discourse of failures great and small is only by way of leading up to the greatest of them all, the quest of Madeira tunny. It happened thus:

During the first month of the present year, the Field published a most interesting account of tunny-fishing with rod and line by Colonel Stead, who had spent the winter at Funchal. He threw out the suggestion that these splendid fish, which are identical with the famous tuna of Santo Catalina, might be caught on the rod by anyone so enterprising as to try. There is a mood of absorbent vanity on which a challenge so friendly 
lights with fatal results, and in such a mood, and in the most comfortable armchair in the smoking room of the Sports Club, that Field article caught me on the morning of its publication. I was due at a matinée that afternoon, during the whole performance of which the spectres of gigantic tunny floated between me and the stage. Back to the club I went and wrote to Messrs. Donald Currie, to Colonel Stead, and to one who is without doubt the greatest living authority on tuna fishing, Mr. C. F. Holder, whose work on the big game of the sea is one of the most thrilling pieces of angling literature in print. After some little change in my plans, I was booked to go out in the Armadale Castle leaving Southampton on April 15th, and I can confidently say that scarcely a day of the remaining three months passed without my worrying someone fresh. One correspondent got more than his fair share. In an unhappy moment for him, I was furnished with a letter of introduction to Mr. Maurice Faber, an old resident in Funchal, and to him I believe I wrote three letters each mail until the date of sailing. He read and answered my letters with a patience that was more than human, and he engaged for me the best skipper and crew that could be found in the place. The terms, proposed by myself, were $£ 1$ a day, with a bonus of 10s. for every fish of $100 \mathrm{lbs}$. or more, the men to 
keep the fish. Alas, I was never called upon to exceed the daily minimum, and of fish there were none to keep. Besides worrying Mr. Faber, who, after all, could only retaliate once a week, I turned my pen on anyone within reach who had ever caught large sea fish; and Mr. Turner Turner, Mr. Rowland Ward and many others were bothered in turn. Tackle I begged, bought, or borrowed on all sides. Mr. Turner very kindly lent me a complete tarpon outfit, including one of Vom Hofe's reels, with which his wife and he had enjoyed mighty sport in Florida. Messrs. Farlow lent me special hooks of the right pattern, lines and a spare rod. Messrs. Carter provided me with a beautiful line of copper wire, made specially for the experiment, and 300 yards long. Though the supreme test in view was not forthcoming, the way in which it sank vertical in tides that took other lines almost to the surface, as well as the condition in which it came out of a very trying entanglement with the anchor rope, caused me to revise a hitherto hesitating appreciation of this material. I had cabled to E. Vom Hofe for the largest tuna reel in his store, as Turner's was rather small. As some indication of my state of mind at the time, I may as well confess that I apparently omitted to sign the cablegram, as a result of which the reel did not come. Messrs. Bernard, however, stepped into the breach with 


\section{A FORLORN QUEST, ETC.}

a very serviceable mahseer reel, fitted with their patent brake, which, though lacking the complex mechanism of the orthodox American reel, would, I doubt not, have been found efficient if the tunny had given it a chance to do itself justice. Such is an outline of my preparations for the trip, and I have devoted so much space to them, not merely because the preparatory stage is often the most interesting reminiscence of such expeditions, but by way of reviewing them in the reader's company and asking myself whether they look incomplete. Many heads are better than one, particularly when that one is mine; but I confess to have been a little staggered by a friendly criticism, which Mr. Rowland Ward made on my want of success. " Ah," he wrote, " you should have taken a guide from Santa Catalina, used to the work." I venture to predict that if anyone inducts a Californian guide into the mysteries of tunny-fishing at Funchal, he will as likely as not be shot for his forethought.

Equipped, then, with a care and completeness, with an outfit, compared with which the kit of a Knight Templar setting out of old to the Crusades was slipshod, and accompanied by a friend, who shall herein figure as A. K. M., and whose fishing had hitherto been for Irish and Norwegian trout, I embarked in-April on the Armadale Castle and had a blameless and unemotional

$16-(2272)$ 
passage to Funchal. On the morning of our arrival, tunny were strewn in careless profusion on the beach. They were pointed out to us by an agent of Messrs. Blandy, who came on board as soon as the anchor was down, and he further raised our hopes by saying that the bay had not been so full of those fish within the memory of man. Later in the day, after we had settled in our quarters at the Palace Hotel, which, like most of the rest, is the property of Mr. Reid, I had the courage to seek out Mr. Faber, who quickly put me at my ease, and indeed almost made me regret that I had not written more fully. Both he and Mr. John Blandy told us that tunny had not been so cheap for years. Indeed, the poorer class of natives would not buy any meat, so plentiful was that satisfying fish in the market. Both predicted great and immediate success, and, with our hearts singing of triumph on the morrow, a triumph which we had promised to cable home, we fixed 3 a.m. next morning for the first essay and interviewed the Reis (captain) of our boat, that he might understand to bring her round to the private steps of the hotel. How great a convenience that private landing was throughout our stay can be appreciated by those who know how keenly the sensitive angler feels marching through busy streets in his indecorous clothes when he has no fish to show the crowd. We retained the services 
of an interpreter at $5 \mathrm{~s}$. a day. This excellent fellow knew just sufficient English to ensure misunderstanding all round. Without his services, gesticulation and an occasional oath in any language but Portuguese would have made matters go quite smoothly. His name was "John." Every native is named either "John" or "Manoel." And for us he had a sentimental and auspicious interest from having accompanied Colonel Stead on his successful capture of tunny on the native tackle.

Confident of success, having mentally worded our cablegrams, all but the individual weight of the fish, we took a bullock-car back to tiffin and spent much of that afternoon fixing up our tackle.

Five minutes after three next morning, with a pale moon gleaming coldly on the beautiful terraced garden, robbing rose and geranium of their colour and revealing the ghostly outlines of cactus and of palm, three determined anglers, fortified with an early meal prepared by themselves, stole, like thieves in the night, down the winding slope and forty minutes later got on board the boat, which at that moment arrived with remarkable punctuality at the steps. It is not actually on record, but it is surmised that Madeirans are lineally descended from him who said "I go, Lord!" and went not.

Scarcely a breath of air helped us along until 
the levée in the East, and for the next three hours, as day gained the mastery, we were drawing slowly through the water, the sail hardly filling out and glad of assistance from the long sweepers, at which the men toiled like the galley slaves they looked. At last, without apparently taking up any particular marks, the Reis put down the anchor and signified that we should begin fishing. A lively mackerel was dipped out of the bait barrel, into which a fat boy, with no other very evident ambition in life, had been zealously pouring water ever since the sun was up. The hook was fixed in the back, and the Reis asked us, through John, to let out about 60 fathoms to start with. Plumb went my, wire line, Turner's reel, which held no more than a hundred fathoms of it, running out easily with the weight of the $2 \mathrm{lb}$. mackerel. No tunny accepted the invitation, and I have since reflected that if one had, I must either have gone overboard, or lost a lot of another man's tackle, not the most agreeable alternative for a holiday. In California they played these huge fish from a small boat, which the fish is free to tow until tired out. This puts the minimum of strain on the rod and gives the line every chance. Anchored, however, in water of such depth, there would only be one chance in a thousand of saving a heavy fish, even if the first rush did not decide the issue. There was an agony of suspense, for we did not then 


\section{A FORLORN QUEST, ETC.}

know that on the very night of our arrival the tunny shoals had gone off to Porto Santo, forty miles distant. We sat for hours divided between the ridicule of not getting even a bite and the fear that a bite might mean disaster. At length we asked the Reis whether we could not fish drifting about, so as at once to cover more ground, a good plan with all shoal fish, and slightly to lessen the risk of breakage with the anchor down. Thanks to John's skilful interpreting, our elaborate suggestion was construed as an order to return home, but we contrived, much to the disgust of the crew, to make our real meaning unmistakeable, and the Reis, to do him credit, took the correction in good part. Indeed, he was a cheery fellow, and we took a fancy to him from the first, though this was our only outing in his boat. The primitive anchor was once more at the bow, and for two or three hours more we drifted about, fishing at times with as much as 80 fathoms off the reel, to allow for the drift, but with no result. A grampus of great size was cruising about a couple of miles to leeward, and the presence of that cetacean, was, the Reis gave us to understand, the cause of our bad luck. Whatever the cause, the result was undeniable, and eventually, after having sat patiently fishing for quite five hours without a touch, we gave the order to make for home in real earnest, particularly as there was a favourable 
breeze from the southward. On the run in, we acquired the only two trophies of the day, a turtle, which one of the men picked off the surface of the sea, where it lay basking in chelonian luxury, and a wreck-fish weighing about a pound. The latter was swimming after the boat, three or four feet below the surface, and one of the crew actually contrived to gaff it in that position. Those who are skilful with the gaff, as well as gillies generally, will appreciate the difficulty of gaffing so small a fish so far below the top of the water and from a boat sailing at any rate four knots an hour. The turtle was of the hawksbill kind, common enough in the Atlantic and reducible to very palatable soup, though not the equal of the aldermanic favourite. Two small crabs (Planes minutus), evidently parasitic, clung to its tail. These I put in spirit and the turtle I managed to convey alive to the $Z$ oo a month later, in company with a second, of smaller dimensions, which I purchased alive in the Funchal market for the ruinous sum of sixpence. Thus ended our first failure, and so easily does the angling temperament veer between the clouds and the pit that we now doubted (with more reason perhaps than we suspected at the time) whether we should ever hook a tunny, much less ever kill one. There are men in every walk of life who, so to speak, set out with a flourish to catch tunny and succeed 
only in catching turtle, and with these failures we henceforth grudgingly associated ourselves.

The second failure was enacted on very similar lines, only under another captain. Our own vanished after that day-the next was Good Friday, and at first we attributed his absence to the Easter Holidays - and we saw no more of him until the last week of our stay. Day after day, even when the holidays were past, John reported him at Porto Santo. Several explanations were offered of this embarrassing defection of the man retained to look after me. One was that, in view of the departure of the tunny to Porto Santo on the day of my arrival, I was accounted a Jonah (a minor prophet still, for all the advance in nature-teaching, popularly associated with great fishes), to tempt Providence in whose company the daily sovereign was inadequate recompense. Another hinted that a market rumour had gained currency to the effect that I was spying out the land, under the guise of sport, with a view to the establishment of a commercial fishery with improved engines. That anyone, however, who had seen the innocent behaviour of our rods that first day could ever again credit us with sinister designs on the fish seemed impossible, even in a community where piety and suspicion are good comrades. The most obvious explanation of all, the fact of these fishers having 
followed their prey to the island where they were known to have migrated, does not seem to have occurred to anyone, but such was, I have since had reason to believe, the very simple construction that we ought to have placed on their behaviour.

The presence of tunny at Porto Santo was reported day after day. Not a boat was to be seen fishing off Funchal, though at the time of Colonel Stead's visit to the grounds I was told the bay was studded with the busy argosies. To follow this recalcitrant mackerel over forty miles of ocean to a small and isolated island, where we should for the period of our stay be cut off, even as regards electric communication, from all the rest of the globe, looked at first sight a harebrained scheme, but the more we thought over it, the more it liked us. Perhaps, too, our hand was forced by the remarkable kindness with which everyone made the path smoother, Messrs. Blandy by lending us a launch, to take us over on the Tuesday and call for us three days later, and Mr. C. B. Cossart, as keen a sportsman as any in Madeira, by promising to accompany us and bring his tents and men. Clearly, everything pointed the way to Porto Santo, or rather to a little satellite known as the Ilheo de Cima, inhabited only by the lighthouse-keeper, his wife, his children, his goats and his assistant, one who 


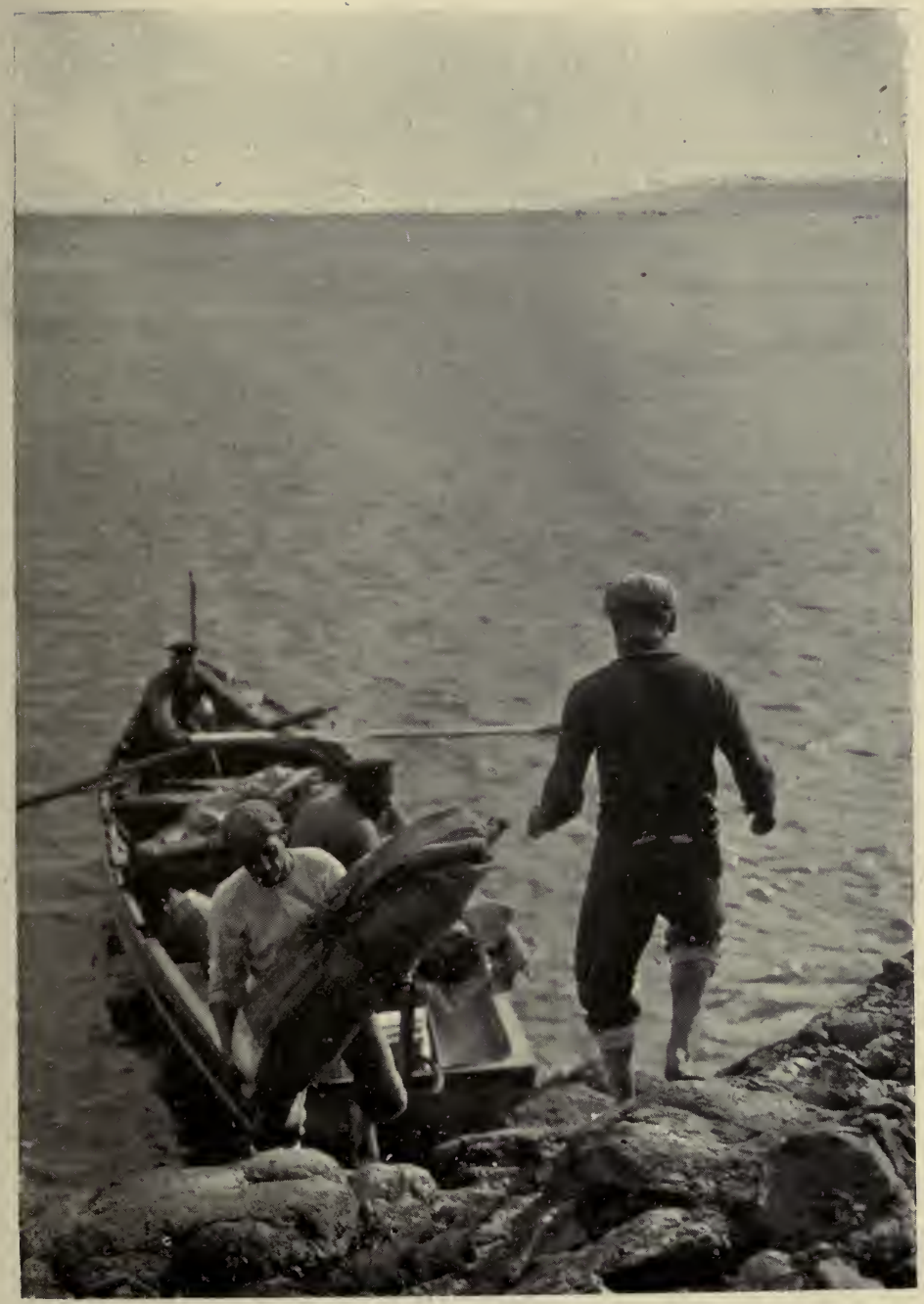

BRINGING THE TENTS ASHORE 
in his time sold hats of the latest fashion to the young bloods of Funchal.

Thither to the island of our last hopes, sped the Falcon one breezy morning in May, and as she dipped and somewhat rolled in an exceedingly impolite sea, we were overhauled by the Kildonam Castle, homeward bound. At first sight, the little I. de Cima looked an unpromising rock, but we grew to like it mightily during our three days of occupation, and it was with great reluctance at the last that we saw Cossart's comfortable tents rolled up and taken back to the launch. The glamour of the camping life is apt to be a little overdone by travellers who write books, for they invariably overlook the horrors usually incidental, the noxious insects, prowling beasts, thievish natives and climatic trials ranging from cataclysmic rains to cyclonic winds. On this occasion, however, perched on a little ledge, snug against the cliff, and within fifty yards of the Atlantic breakers, I can swear that none of the usual drawbacks (and I have known them elsewhere) interfered with our $\therefore$ enjoyment of the perfect peace. There were no insects, though spiders of great size and appalling mien abounded on the stony plateau atop the cliff. The only fourfooted visitors were a most friendly mongrel dog from the phare and a few goats, which their owner now and then drove to distraction by hunting. 
them with a borrowed rifle of Cossart's. On one occasion he with great address hit an old buck (not, I believe, the one intended) with one out of fourteen cartridges and brought it to its knees, though it nearly sent him over the edge of the cliff when he went to secure it. The poor brute was, however, all but mortally hit, and it was a relief when he presently, with the help of the retired hatter, succeeded in pushing it down the slope and finally killing it at the water's edge. The hatter did the gralloching, and a very pleasant job he made of it within about six yards of our dinner table.

It is not, however, of the big game shooting on our island that I wish to write. The day following our arrival, we were up with the sun, or, to be accurate, about an hour earlier, catching all manner of little fishes in the rock pools. Little breams and blennies of several species came so greedily at the tiny hook that in a few minutes I had an assortment in a pickle jar in spirit. Those unsophisticated little creatures were even more free of guile than my perch and bream in the Baltic estuary had been fifteen years earlier. It is improbable that several of the pools, those at some distance from the landing place, are darkened by man's shadow from one year to the other, as a result of which anything tasty is at once seized, in full view of the angler, and without a 
thought of danger. We had only to drop the hook, baited with a fragment of limpet or whelk (there were no mussels on those rocks), in the midst of a seemingly empty pool, when from under every rock or stone, from behind every curtain of waving weed, little fishes darted to it like iron filings to a magnet.

The sea ran so high that morning, that even old "Beiçana" (the Portuguese love nicknames, and this one had reference to our friend's generous lips), an experienced veteran, declared the weather unsuited for tunny fishing. "Beiçana," as will be seen from my photograph, in which he is holding a pair of newly caught becuda, or seapike, is of that strikingly Moorish type so noticeable in the fishermen of those islands. The traveller who is familiar with the Barbary States will find among the loafers in the Funchal fishmarket many familiar ruffians, as truly Moorish as any that years gone by sailed out of fair Salee to cut a throat and. scuttle a merchantman. Morocco may have been swept from the seas; she may even have come low among the land nations; but undeniable Nature has set a hall-mark on many of those seamen in the Spanish and Portuguese archipelagoes of the eastern Atlantic, linking them with the merry rovers who raided, burnt and loved in the golden days of their seamanship. Nature has set the stamp, and time 


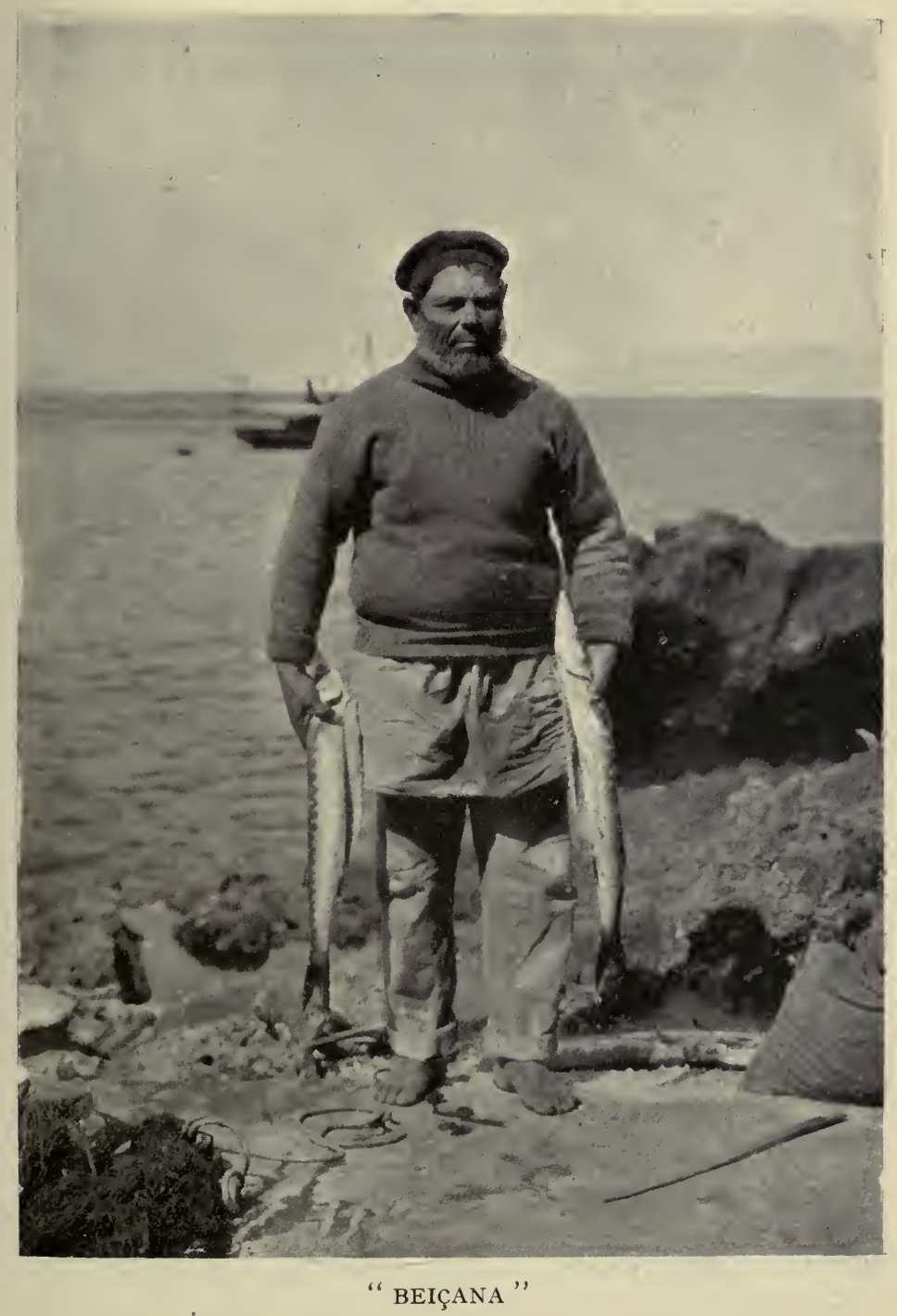


cannot efface it. Our first morning, then, between breakfast and lunch, was spent at the lighthouse, which not to see and admire would have been to offend our only neighbour greviously : and on the plateau before it, where we turned over stones and dislodged the great $L y \cos a$ spider that lurked under two out of three. This arachnid (L. portosantana) is a tarantula, closely related to, though not identical with, the species found in Madeira, and Deserta, a neighbouring island owned by Messrs. Cossart and Hinton. If feeds on small land-molluscs, and masses of the shells, sucked dry of their occupants, lay beneath each stone. I took a number of these spiders home to the $Z$ oo, together with a smaller black one, commonly regarded as fatally venomous, though in all probability quite harmless, and some males and females of the zebra-spider. The last-named spun its strong webs in every clump of cactus in the hotel garden, writing across it that curious zigzag white hieroglyph, which naturalists gifted with a ready imagination have interpreted as arachnid for "Will you walk into my parlour ?" Those, however, who know something of the animals' anatomy recognise in the so-called "writing" a means of using up superfluous building material. All my cargo of spiders, some twenty in number, lived through the voyage to England without food. Every effort was made by myself and my 


\section{A FORLORN QUEST, ETC.}

cabin-steward to obtain flies for them on the Carisbrooke, but a violent head wind, which lasted all the way from Funchal to Southampton, blew every fly out of the ship soon after we left Madeira. To atone for the lack of solid food, I was extra careful to sprinkle them every few hours with water, as I had them in boxes specially designed for that purpose ; and it is well known that spiders can go a considerable period without food so long as they get plenty of water, for they are greedy drinkers. When I handed them over to the Zoo, they were in excellent condition, and Mr. Pocock at once found them suitable quarters in the warm Insect-House. The rest of my living luggage, consisting of the two turtles, a-lizard from Porto Santo, and twelve others, somewhat different, from Madeira, went to the Reptile House. The turtles had their salt water bath on board every morning before I had my own, but the lizards packed for me by Padre Schmitz, whose museum at the Seminario is one of the sights of Funchal, survived the journey in a linen bag, without further attention. These hints on the transport of such living souvenirs of the trip are given in case they should be of use to other people with a fancy to do likewise.

We also derived much amusement from laying down and taking up Cossart's trammels, of which there were two, as well as a long single net. The 
principle of the trammel is more ingenious perhaps than that of any other net used in fishing. It consists of three nets, two outer with very large meshes, and an inside one, double their length and height, and with a very small mesh. A fish strikes one of the outer nets and passes through it, only to encounter the long net, which it pushes before it, being unable to go through so small a mesh, through the corresponding large hole in the third. Making a dash for freedom, it shuts itself inextricably in a blind pocket, and there it remains until the net is visited next morning, for, unlike the trawl or drift-net, the trammel has the great advantage of catching fish while its owner is comfortable in bed. Down went the trammels each evening, and up they came in the morning, yielding good measure and some variety. The bag included dogfish (Mustelus) with living young, many of the embryos being very advanced, wrasse of large size, becudas (Sphyrana), powerful seapike these last, which at times give good sport on whiffing tackle, whiprays, red mullet and grey, both of large size, and a crayfish without claws, much esteemed as the nearest approach to a lobster which those islands produce.

One of the most amusing petites pêches was from the rocks at sunset for sargo, a game, silvery bream with black stripes, which grows in those waters to rather more than a pound weight, or 


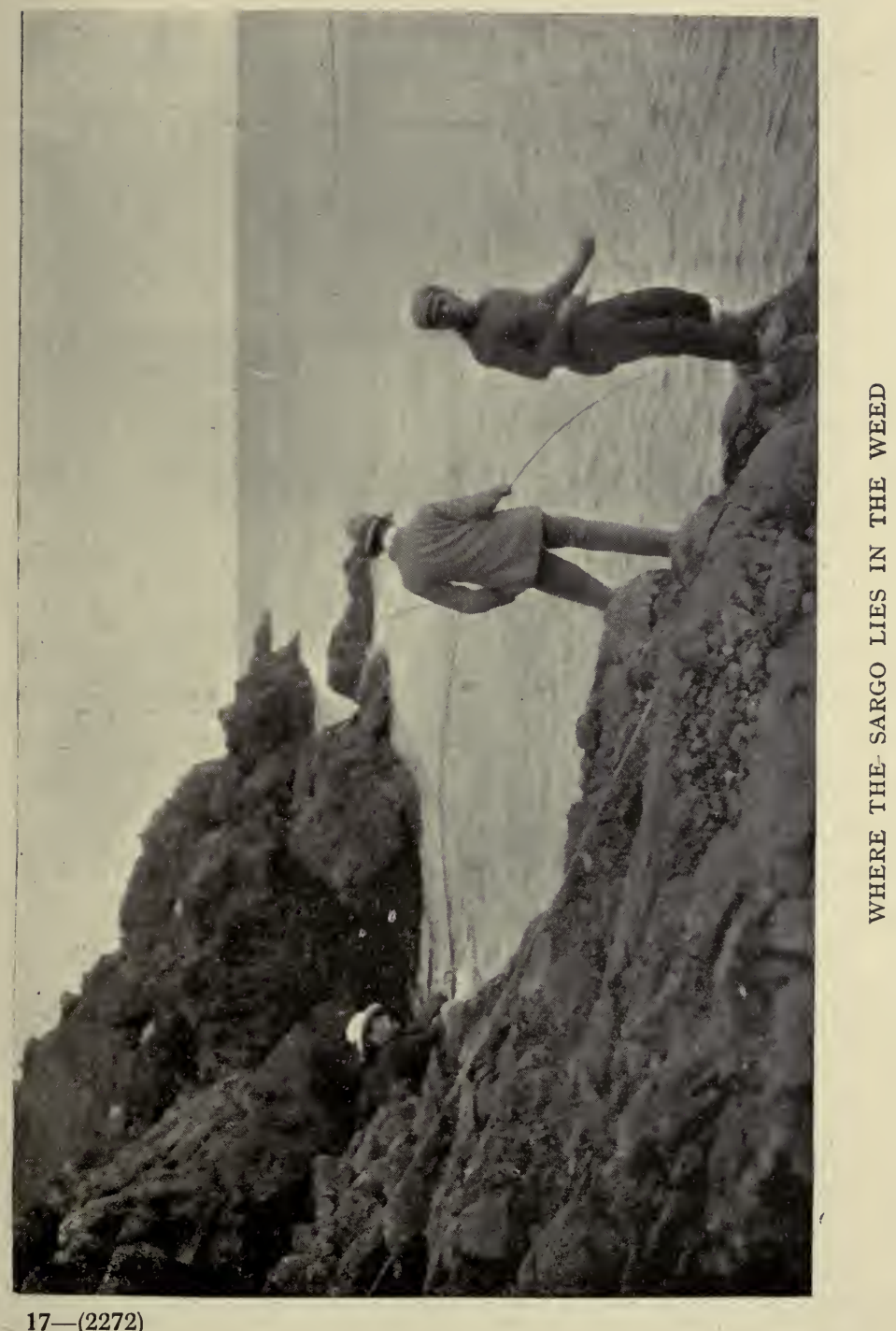


such at-any rate was the largest that we caught. An ancient bard, quoted by Izaak Walton, relates a quaint scandal of how the sargo goes ashore courting she-goats, and certainly the I. de Cima does provide that attraction, for she-goats are the only females in evidence. The sargo is caught on a single cane rod and tight line, and the hook is baited with the fleshy portion of a crab's leg. This crab is by no means scarce, but during the day it is as shy of pursuit as an undischarged bankrupt; and more than once, as time was limited, Cossart resorted to the somewhat laborious and certainly expensive plan of stalking each crab with his rifle, picking it off on a rock before it could scuttle out of sight and then sending Manoel to retrieve the game before the Atlantic washed it away. Manoel, an admirable gillie on such occasions, played a still more important part in the proceedings. Someone in the Latin Grammar used to offer, I never understood under what circumstances, to perform the function of a whetstone. Manoel-was more useful still, for he performed the function of a sprinkler of groundbait. Chewing a fascinating mixture of these crabs and sweet potatoes in his mouth, he would, with the calm precision of a Zoo llama bedewing a silk hat, project it, a little at a time, round our lines. The sargo, like the black bream of Australia, bites so tenderly that it requires a little practice 
to strike just at the right moment, but when actually hooked on the light cane and tight line, it gives great play until jifted out on the rocks. In addition to sargo, we caught a number of seascorpions and wrasse, which was just as satisfactory as catching leatherjacket when after grouper. Indeed, the remembrance of those Australian days was intensified by the rock-climbing which we had to do in order to reach the best pools. Then, when the sun had gone down behind Porto Santo, we clambered back to camp. Swifts screamed against the blue sky, but the terns had gone to roost. A desultory chatter was kept up in a kestrel's nest just above our camp, where the parents were rearing a greedy brood, but the only other birds in evidence so late in the day were Bulwer's Petrel, which flew barking among the cliffs, and nervous shearwaters, which, we afterwards discovered, had a single chick in a nest under one of the biggest boulders beside our camp. No harm, however, came to the nestling from our visit, and even in that short time the parents seemed to appreciate that all was well. There were many other birds on our island : turnstones, gulls, meadow-pipits on the plain up by the lighthouse, rock-pigeons and one or two others. The rest of the land-fauna consisted mainly of the aforesaid spiders and lizards, the latter swarming among the rocks and seeming equally at home 
half way up the face of the cliff or on the lowest boulders within reach of the driven spray. The sight of lizards flashing over rocks wet with seawater is an uncommon one, but what perhaps struck the observer even more was the indifference of these little reptiles to extremes of temperature. They were to all appearance as much at their ease in the glare of the summer sun and in the shelter of exceedingly cold burrows in the cliff.

One other kind of fishing we did close inshore, though from a boat, and that was a peculiar mode of very slow whiffing for large wrasse, known in those islands as "garoupa," a name that once again recalled those futile climbs on the coast of New South Wales. The tackle used for this fishing was an immense cane spreader, the two hooks on which were baited with small pieces of tunny or mackerel. In England such a spreader would be used only from a boat at anchor, but out there the approved method is to trail it quite slowly in moderately deep water, by which means we added to our varied bag a few wrasse, clad, like most of their kind, in a coat of many colours.

On the second morning, Cossart and I decided at daybreak to go forth after the tunny. The wind seemed to have moderated, and, since bad weather of any description is but comparative, it certainly had done so to the extent that it was 


\section{A FORLORN QUEST, ETC.}

to-day possible for the boats to hold their anchors. A. K. M. determined to remain ashore. He had not, he said, been born great, nor did he particularly wish to have greatness thrust upon him, but was content to take his pleasure unambitiously on dry land. The fact is he thought himself a much worse sailor than he really was, and was for ever dreading sickness, but never, to my knowledge, sick. On one rather trying day off Funchal, a day of oily calm but heavy ground swell, he certainly did behave from time to time in a manner that I have not previously witnessed under those conditions. He lay on his back in the bottom of the boat, pulled a sail over his face to keep the sun off, and then broke out in a series of amazing Irish songs, chiefly about brave doings at fairs, which won the heart of the crew. As he never developed this talent for singing at any other period of our acquaintance, I was reminded of Thackeray's confession, that the best thing he ever wrote in his life (I think it was the surgeon's song in "Harry Rollicker") was done when he was desperately sick on an Austrian Lloyd boat.

When Cossart and I had come to our heroic resolution, "Beiçana" was despatched as envoyextraordinary to one of the numerous tunny boats riding at their anchorage opposite our camp to arrange the price of our admission for some hours. Eventually I gave the Reis a sovereign, and he 
wanted (but did not get) thirty shillings, which was only the manner of his tribe. There is no island in which begging is carried to greater per-

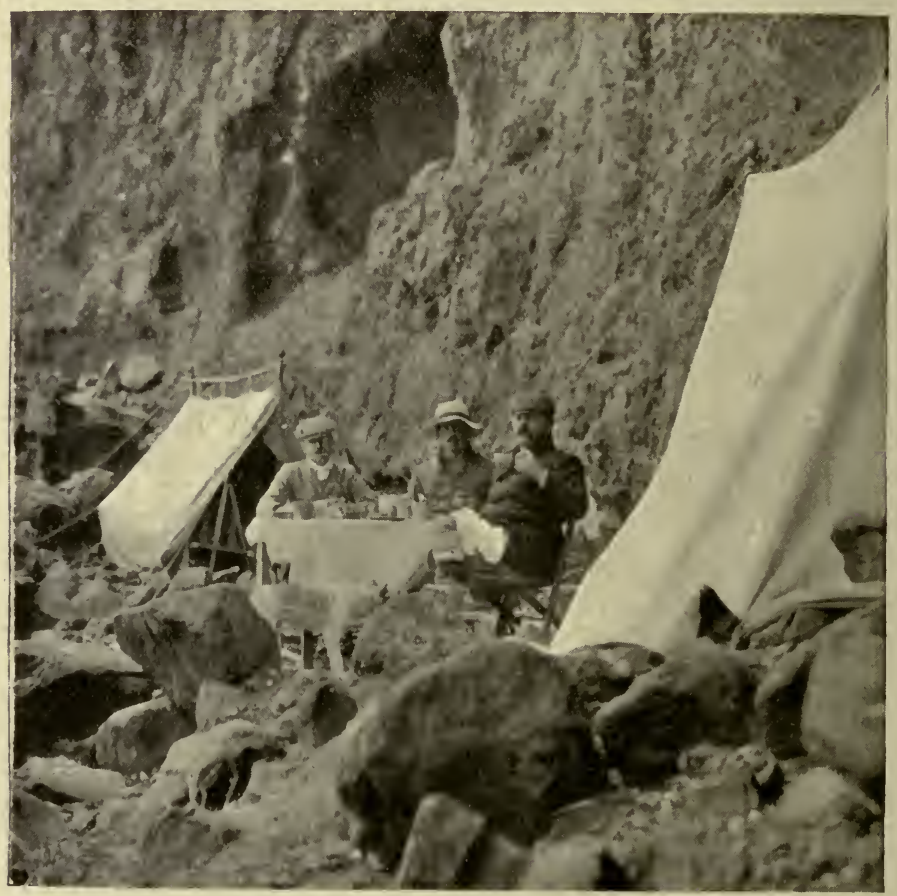

CAMPING ON THE ILHEO DE CIMA

fection than in Madeira. When you have paid your carro-man half again his proper fare, he asks for " something for the boy," and if you gave that also, he would no doubt ask next for something for the bullocks. Indeed, I believe it to 
be a physical fact that the hands of most of the natives are crooked at birth, owing to generations of alms-seeking forbears.

We hurried over breakfast so as to be at the disposal of the Reis the moment he should come for us, and he, having ensured several dollars, fish or no fish, remained at anchor for another two hours. At length we got off, and they put us in a great basket, which apparently held stale bait at other times. It was firmly wedged against the side of the boat, and for this we presently had reason to be grateful, for no sooner were we rcund the point, beneath the lighthouse, than we saw what we were in for. If the sea had looked rough from camp, it resembled at close quarters fancy paintings of the Bay of Biscay out of temper. Up we went on a breaking wave, which drenched the oarsmen from bow to stern; down we came with the vacant sensation, which is so disagreeable even to good sailors.

\section{“.... Salt entered mouth and eyes Often enough...."}

Things went a little more smoothly when the sail was hoisted, but even so the antics of so heavy a boat were not unlike those of an anchored lightship, which had previously been my standard of the tortures of purgatory. We held on bravely, though, and it was not until I had been shot out 
of the basket and into Cossart's stomach that we agreed as to the possibility of overrating the charms of tunny-fishing in mid-Atlantic. A. K. M., we afterwards discovered on comparing notes, must at about that moment have been sitting down to a savoury breakfast of fried becuda, specially prepared for him by the solicitous John. This, be it explained, was not the polylinguist of Funchal, but a most admirable amateur cook, employed, when not conjuring up visions of Delmonico's, in Mr. Hinton's sugar works.

We were now nearing the fishing fleet, eight or ten boats anchored in that fearful sea and behaving like seesaws at a country fair. When within three or four hundred yards of the nearest, out went our anchor likewise, and by the time about a quarter of a mile of cable had been paid out, we were not more than a hundred yards from our neighbour and just in time to see a tunny hauled on board. This looked like business, but one must not judge by appearances. Moreover, I had doubted the possibility of playing a heavy fish when anchored in comparatively calm water off Funchal or Cama de Lobos, but there could be no doubt whatever about the immediate result of an encounter in such a sea as this, with the boat rising and falling ten or fifteen feet as each roller passed under her keel and raced on to the fleet. Even the local handlines, twelve or fifteen hundred feet in 
length, and almost as strong as the anchor rope, are sometimes broken by the big tunny, and when the difference is allowed for between such a line, with coils of slack to meet a sudden strain, and the fine line on a tarpon reel, with no such provision possible, it is not hard to understand our disturbed frame of mind, half longing for the excitement of a rush, yet certain that the tackle would not stand the test.

We need not have worried. Several of the men put out lines, and an unfortunate horsemackerel was blinded and thrown overboard, that it might swim aimlessly around the boat and attract the tunny. This piece of cruelty was unfruitful, and, mercifully perhaps, the tunny stayed away. After we had been buffetted about for a couple of hours and seen another fish hauled into the neighbouring boat, we gave it best. I am not as a rule an impatient fisherman, nor am I particularly nervous of either sickness or shipwreck, but it must be admitted that I never heard the "Home, James!" with more fervent thanksgiving than on that occasion. Even before the anchor was down, we had recognised the futility of fishing under such "Heads you win ; tails I lose " conditions. Still, having followed the shoals for forty miles, only to reach them in the full blast of the north-east trades, it seemed hardly playing the game not to make that one attempt. This 
is not intended as a reflection on the absent, breakfasting member of the party. He and John had other fish to fry.

With this recital of my third, and, for the time being, last, attempt to catch tunny, it seems desirable to offer a word or two of remark on the general prospects of others succeeding where we failed. If success comes out of failure, then failure is not all regret. This is the kind of platitude that one might preach as a funeral oration over a partridge killed by contact with a telegraph wire, only one knows to a moral certainty that in the next gale another bird will in all probability fall dead on the same spot . In angling, however, it is different, or at any rate would be if anglers were as circumstantial over their failures as they are over their successes, if they would tell us of the black-edged, as well as of the red-letter, days.

That tunny of the largest class (Rabilhe) will ever be caught on the rod of Funchal, as tuna are caught off Avalon, is at present uncertain. The conditions of depth alone are so different, and the average sea so rough for small boats, that the chance of success looks remote. There are, however, two smaller kinds of tunny, or at any rate of fishes so closely allied as to go by the same generic name. These are known in the vernacular as Patudos and Avoador; and whereas the Rabilhe weigh anything up to $400 \mathrm{lbs}$., the former of these 
range, as caught for market, from 60 to $100 \mathrm{lbs}$., and the latter from 40 to $70 \mathrm{lbs}$; ; and anyone persevering with these, during, say, the dull, still June weather, should be rewarded with sport. Cossart vowed vengeance on some of these smaller fish in the near future, and A. K. M. left him his tarpon-reel wherewith to wreak it.

The chief difficulty, apart from weather, which I anticipate in connection with the sport at Funchal, will lie in the uncertain movements of the shoals. It is true that the Union Castle boats link Southampton and Madeira so closely that anyone in readiness could, if there were accommodation available, receive a wire in town on Saturday morning and be fishing for tunny on the following Wednesday. By that time, however, the fish might have gone to Porto Santo, and a further journey of 40 miles, only perhaps to be sold as we were, would not command enthusiasm, even though it might deserve it. Nor is the weather, at any rate in early spring, much less capricious than the tunny. Always beautiful on land, save when disappointed tourists ride to the rocks that overhang what should be the Curral, and look out on rolling seas of fog, it is subject to sudden gusts of wind, which, while merely refreshing to the landsman, soon make fishing from small boats uncomfortable, if not altogether impossible.

For these reasons I fancy that the tunny fishing 
will have to be counted rather as an asset in the resources of Funchal for amusing its residents, or at any rate such visitors as spend some months in the island. Sportsmen would in such circumstances be able to pick and choose days offering a combination of fish and fine weather. Anyone going out, as we did, for the inside of a month might not enjoy one day with just the right conditions On the other hand, one day of tunny fishing with rods might, given the luck, amply compensate for weeks of waiting. Those who doubt the supreme thrill of playing a heavy tuna (the same fish, as has already been pointed out) should read Mr. Holder's volume (in the "American Sportsman's Library") on Big Game Fishes, without question the most exciting book on angling in cold print. Writing to me on the subject, Mr. Holder, who, may be regarded as the inventor of angling for tuna, told an experience of his, in which a tuna towed his boat for fifteen hours, covering an estimated forty miles, and then broke away! He regards the chain used on tarpon hooks as unnecessary for tuna, which does not hurl itself into the air, Jike the giant herring, when hooked. It has a habit of keeping well down in the water, he says, more like a shark ; and, as the line is apt to get frayed across the sharp fins on its back, it is desirable to have the piano-wire "leader" longer than the fish itself. 
I followed Mr. Holder's instructions to the letter, and all the native fishermen who saw my tackle admitted that, being so fine, it would certainly be seized before their coarser lines, but that it would as certainly be broken in the first rush of the frantic fish. As the boat was anchored in such deep and troubled water, I was disinclined to criticise their unfavourable forecast.

In addition to the shore-fishing already described, there were two other kinds of sport at Funchal, which served to pass the time and to console us for the tunny that failed.

The first of these was the mackerel-fishing just beneath the windows of the Palace Hotel, or on another ground, just east of the Pontina, which we did not try. At sunset every evening a fleet of from fifteen to fifty small open boats would assemble on an area of not much more then ten acres, so that a neighbourly spirit was necessary for complete harmony to reign. Unfortunately, some of the crews were from Cama de Lobos, naughty knaves and quite unworthy their lovely home with its crescent beach and background of mighty cliffs. These ruffians were suspected of keeping aboard their boats plentiful ammunition of stones, with which to pelt anyone fishing too close to them. That they gave passers by a broadside of very foul language there was no question of suspicion, though any one ignorant 
of the vernacular might merely scent reference to a famous racehorse.

An hour after the sun was gone, when darkness fell so swiftly on the face of the waters as to remind us how near we were to Africa, each boat kindled its torch, and night after night the rival constellations marked the two mackerel-grounds. On more than one evening we sacrificed the pleasures of table d'hôte and took an abbreviated dinner at our own time in order to fish with the fleet, and within ten minutes of embarking at the hotel steps we were anchored on the spot Next to us was a boat from Cama de Lobos, but the occupants on this occasion were peaceable. Cama is the beauty spot on that south coast, and, besides being a busy fishing centre, it is in the chief winegrowing district on the island. It has, moreover, the advantage, from the visitor's pcint of view, of lying on the New Road, practically the only one in all Madeira on which you can get a canter of more than a hundred yards without a more than sporting chance of breaking your neck. The road goes, in fact, from the hotel gate. The town owes its name to the traditional occurrence of seals among its rocks, but these have long since disappeared, and none occur in these days nearer than the islands of Deserta and Bugio, away on the south-eastern horizon.

We are anchored as close to the Cama boat as 


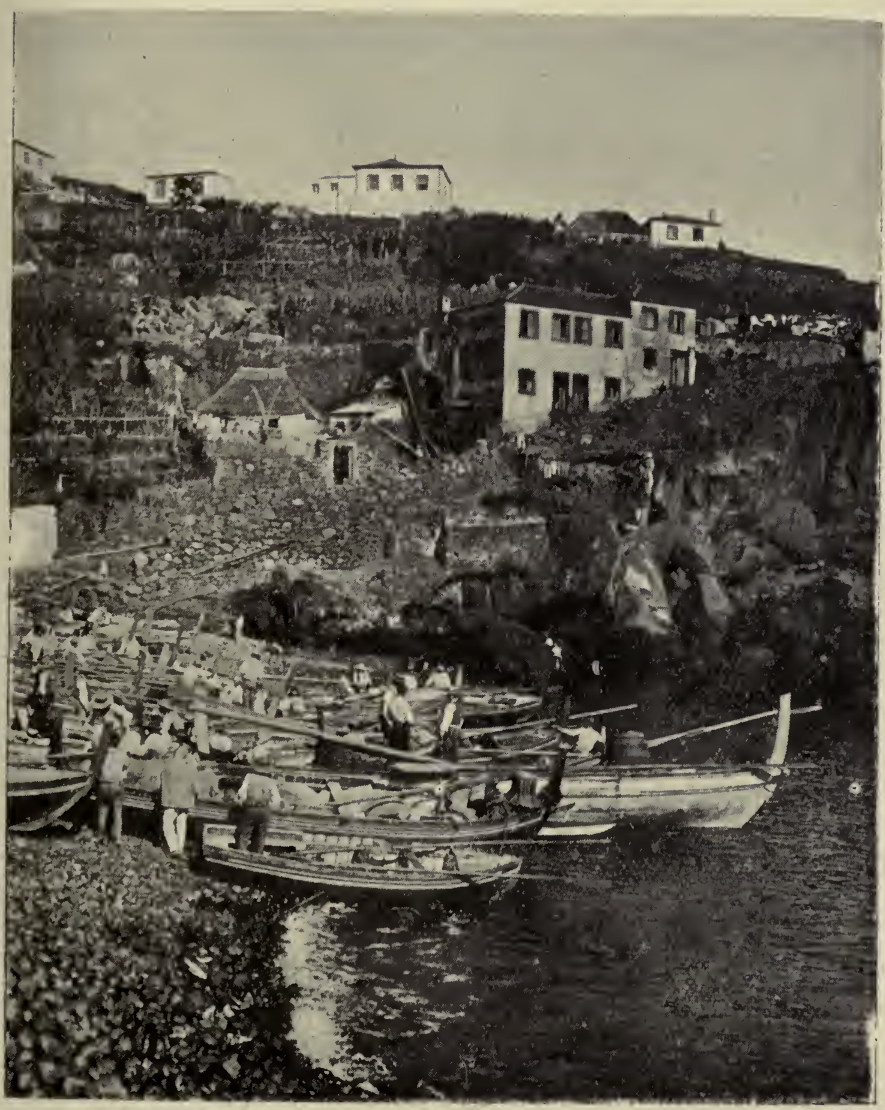

TUNNY BOATS AT CAMA DE LOBOS 
policy dictates, and now comes the making of the groundbait. This is a mixture of tunny and sweet potato (a convolvulus), and it must be chopped on a board when the boat is anchored over the fishing grounds and not before. The noise of this chopping reaches us over the water from boats all around, and the fishermen have the firmest belief that the orchestra of choppers has the same effect on the mackerel as the nasal cry of the muezzin on true believers. John, or Manoel (every fisherman on the island will answer to either name, or to both, for a few reis) is busy pounding up the bait, while Manoel, or John, gets ready the cane rods and reluctantly obeys orders, and removes from two of them the blunt native hooks, for which we propose substituting a couple of stripped sea-trout flies from A. K. M.'s bulging fly-book.

The sea is beautifully smooth, and the tide, diminishing every moment, runs to the eastward. Surely, the use of tunny as bait for mackerel is setting a whale to catch a sprat! A little of the groundbait is flung over the side, and on each hook is impaled a little cube of tunny, after which the tackle is lowered in the water, rod and all going under. Local practice decrees that the rod shall be held point downwards below the surface, and this, with some doubts, we do. Presently, there is a tweak at my bait. I strike, and not being 
accustomed to fish with a submerged rod, miss the fish and have to bait the hook again. A. K. M. does the same, and after we have missed the next half dozen, we anathematize the local method and fish, as we should at home, with the rod out of water. This makes a difference, for, instead of getting bites and missing the fish, we get no bites at all, for the baits are too high in the water unless the rod is kept well down. One of the men makes us understand by signs that by and by, when the torches burn, they will feed close to the top, but that until then we must fish as deep as possible. Down go the rods again, and this time, having served our apprenticeship of failure, we simultaneously hook fish, horse-mackerel both of them, which play well on the tight line and pliant cane, until at last we lift them into the boat. The horsemackerel, or scad, is always the more plentiful of the two, though a two-pound mackerel gives such excellent sport on A. K. M.'s rod that we resolve to meet again on the Cornish coast, where alone in the south of England the water approaches to the clearness of the open Atlantic, in a couple of months' time and try the same tactics over there. And so in part it came about. We did meet there, but too early in the season for the big mackerel.

All those other boats are fishing in dead earnest, either for tunny bait or for the morrow's market. We alone are there for the fun of the thing; not $18-(2272)$ 
anbther man in all the fleet would call nightfishing fun unless he had recently had sunstroke. And so we leave them. There is a pathetic side to fishing side by side with those to whom it means

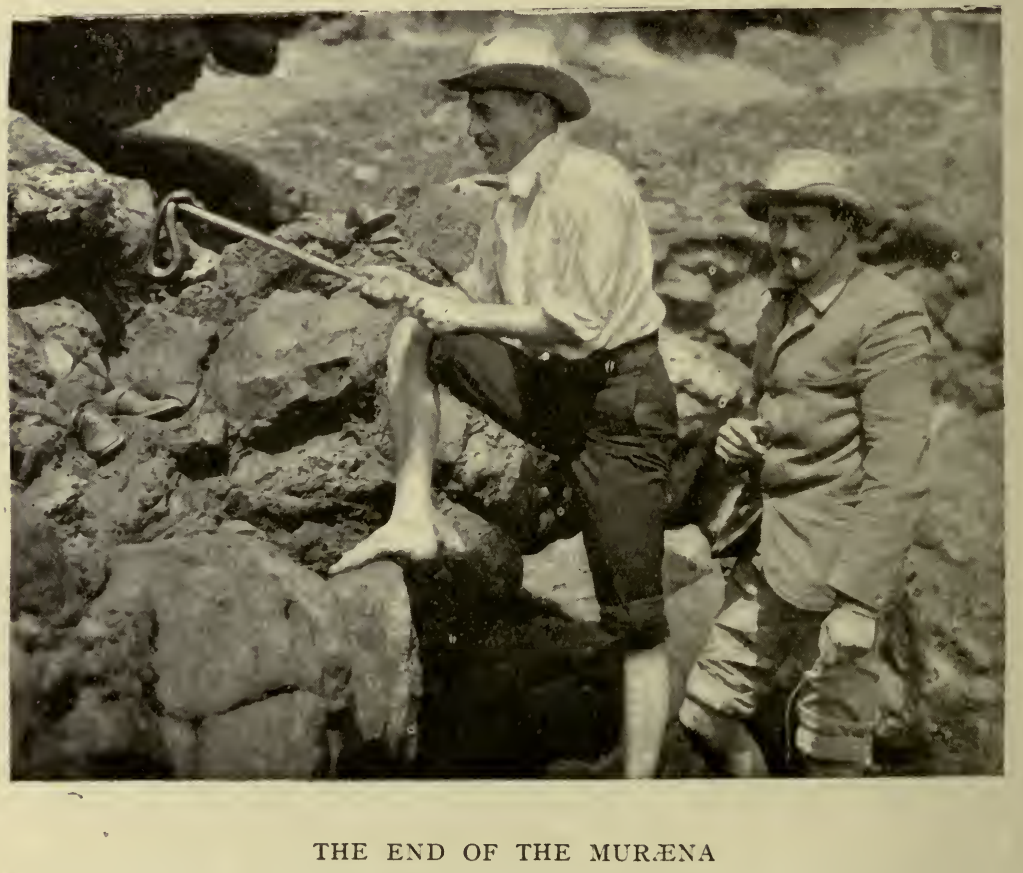

bread. When you are tired of either failure or success (for the one can be almost as wearisome as the other), you go back to port. Those others, the brave and underpaid, stay on and wring their meagre harvest from the hostile sea. 
The other fish, with the capture of which, by much less sporting but not less amusing methods, we passed some of the pleasant hours, was the muræna, a first cousin of the conger eel, but fiercer in manner and appearance. The conger, whose bite is said to have left its mark on the hind leg of the gentle Diplodocus, is bad enough in all conscience, but compared with the muræna it is as a silkworm to a rattlesnake. It is singular that the waters contiguous to Madeira should have produced two such æsthetic extremes as the muræna and opah, though there is just one fish worse even than the eel, and that is the Spada, one of the scabbard-fishes. As this nightmare of the deep sea is delicious eating, Nature no doubt has bestowed its ugliness as a protection. She adopts a similar plan with some of those vestals who, vowed to literature, devote their lives to a great work of extraction in the dim shades of our public libraries. Otherwise, outward beauty and delicate flavour are often found united. The strawberry, the peach, the red mullet and the golden plover look the royal dishes they are. The spada, on the other hand, unquestionably the best table-fish in Funchal, looks as if its father had been the sea-serpent and its mother a griffin. It baffles description in the colourless phrase of modern scientific writing and demands rather the poetic flights of the older observers, whose 
warm imagination was an agreeable substitute for unromantic accuracy. "Some fishermen," wrote such an observer in the Sporting Magazine for May, 1820, "lately trawling in Emsworth " Harbour, caught a fish called the 'lioness.' "The resemblance it bears to that animal is in "its claws and the roar of its voice. With a " mouth full of teeth, its tongue is like a Newfound"land dog's; the tail spreads like a fan, and when " expanded is ten inches wide."

The foregoing is a fairly reasonable impressionist picture of a seal, but to class it as anything but a fish would rob it of all interest.

I wish that this gifted writer might have encountered a spada in the half-light. Its tender face would have tested the resources of even his vocabulary.

But I leave my muræna. Unlike the spada, which has to be caught on long handlines in deep water, he lurks among the rocks near low-water mark; nor would I, having seen him exorcised, wade among those foam-flecked pools in the twilight for a boatload of new-minted dollars, for the creature has its share of sharp teeth and is imbued with a determined ferocity in attacking its food, before which even Sandow himself might quail barefooted.

So repulsive a child of the waters might well be eft undisturbed, were it not that its capture is 


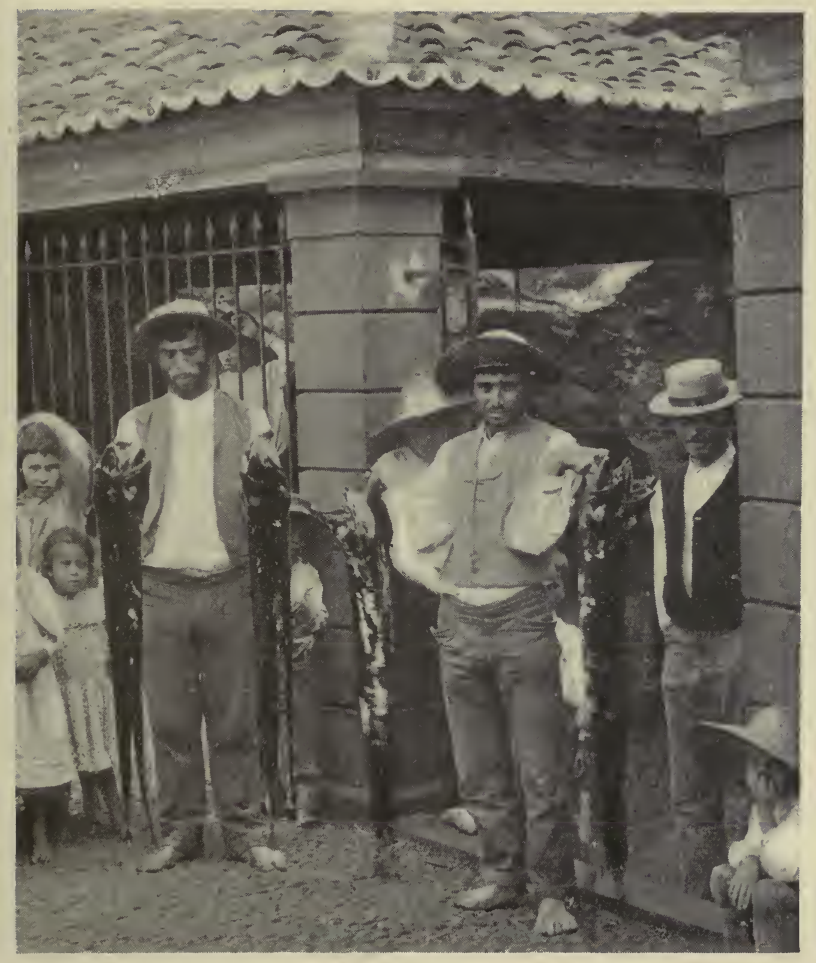

Photo

Peresirello

SPADA FOR THE MARKET 
rather novel and amusing. As with the mackerel, the charm of sound is employed as an attraction, and a rude equivalent of music is made to soothe the savage beast. The native fisherman, in fact, sings and whistles to his "Moreia" for some minutes before effecting a capture; and the burden of the chant, which is in three verses and sung in that wailing voice equally familiar on both sides of the Straits of Gibraltar, is roughly as follows :

\section{Moreia do Rolo \\ Vem a terra \\ Comer polvo \\ Moreia pintada \\ Vem a terra \\ Regalada \\ Moreias todos trez \\ Cader qual \\ per sua vez}

In order to appreciate the meaning of these verses, it must be explained that there are two species of muræna on that coast, the one of a uniform grey, the other (the pintada) of a lighter yellow with black markings. 'The first of these is generally invited to come on shore and bite the dust ; the second is bidden to come and enjoy itself. The third verse refers to a very curious fact. It 


\section{A FORLORN QUEST, ETC.}

says in intent "Let all three murænas fall, each in his own way;" and it is a well known fact, of

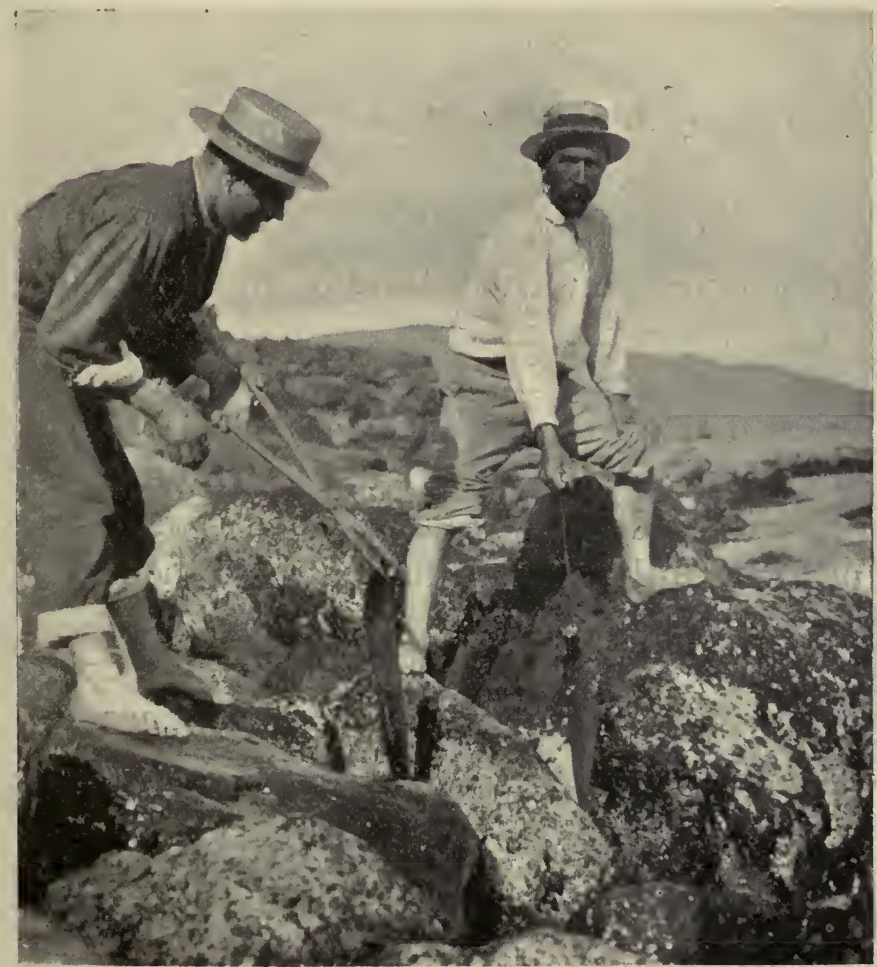

SLIPPERY FOOTHOLD

which I am quite unable to offer any original, or borrowed, explanation, that, in nine cases out of every ten, three of these fishes are caught in company. I regret not having made any observations 
on the proportion of the sexes in this singular partnership, otherwise polygamy might have explained the uneven number, but it is a mystery worth clearing up by someone with better opportunities.

The invocation usually ends with a final

Quo, moreia, quo!

and then comes soft whistling between the closed teeth. While the music is working its subtle spell, the man dips in the water a slab of tunny, so putrid on occasion that it ought to attract murænas even from the Canary Islands. Again and again he dips this alluring food in the water, squeezes it in both hands, so that fragments drop back into the pool and are carried by the force of each wave into every cranny where an epicure may lurk. This gloomy performance, always accompanied by the chanting, may be protracted until more tunny is required, or it may meet with immediate and well deserved success. Suddenly the man's attitude is rigid. He has seen the sinuous form of a muræna glide into view from beneath a rock. Still singing and whistling, a performance which he continues almost unconsciously, he quietly lays down what remains of the bait and, making as little fuss as possible, reaches for one of three implements, with which to secure the eel. This may be done with a baited 


\section{A FORLORN QUEST, ETC.}

hook on a yard of gimp attached to piece of wood. This is presented to the muræna, which strikes at it again and again in a kind of blind frenzy, evidently guided by the scent (which is not surprising), as it will even strike it out of water, where in all probability it is quite unable to see. Another plan is to use a pair of serrated tongs, with which it is bodily gripped. Cossart kindly gave me a pair of these, and a London maker, who saw them, has since asked permission to copy them for use in conger-fishing. The third, and in some respects the least unsporting, way of catching a muræna, since it involves a good deal of skill, is to secure it in a running noose worked in a hollow cane. The novice invariably allows too much or too little for refraction when attempting to use one under water, but the muræna, under the combined charm of the stale fish and cracked voice, is so emboldened that it generally waits around until it is caught by accident or design.

The natives hold it in wholesome dread, and whenever they catch one, it is beaten to pulp on the rocks, so as to make assurance doubly sure. Nor am I prepared to regard the precaution as superfluous after having seen one, that had been left for dead, turn with such suddenness on a barelegged man as to make him overbalance and fall on his back.

Such is the gentle creature, which the ancient 
Romans, in what are appropriately styled the " good old days," fed on spare slaves. In Leghorn we used to spear it at night, that is to say when we could remember to miss our own feet, which generally had first call. It cannot be claimed that any of these methods come, strictly speaking, under the head of "sport," yet so stubborn a creature would not be manageable on ordinary gear.

I have not, if the Fates are kind, baited my last hook in the waters of Madeira. First tried in the spring of the year, that is not a climate to taste but once. The beautiful bay, the delicious bathes, the mackerel fishing within ten minutes of your bedroom, the pleasant canters in the cool of the afternoon to Cama de Lobos, the slower and more ambitious ascent of mountain sides to get amazing views, the cooling return by sledge to sea levelmemories like these, to say nothing of a hospitality that those only can appreciate who travel, invite return. Then there are the tunny. They have yet to be reckoned with. So far, it is they that have done the reckoning, but the account is not yet closed. That the smaller kinds at any rate are occasionally caught napping is proved by a yarn which I had from a veteran sea captain, who was on one occasion bound from Gibraltar 


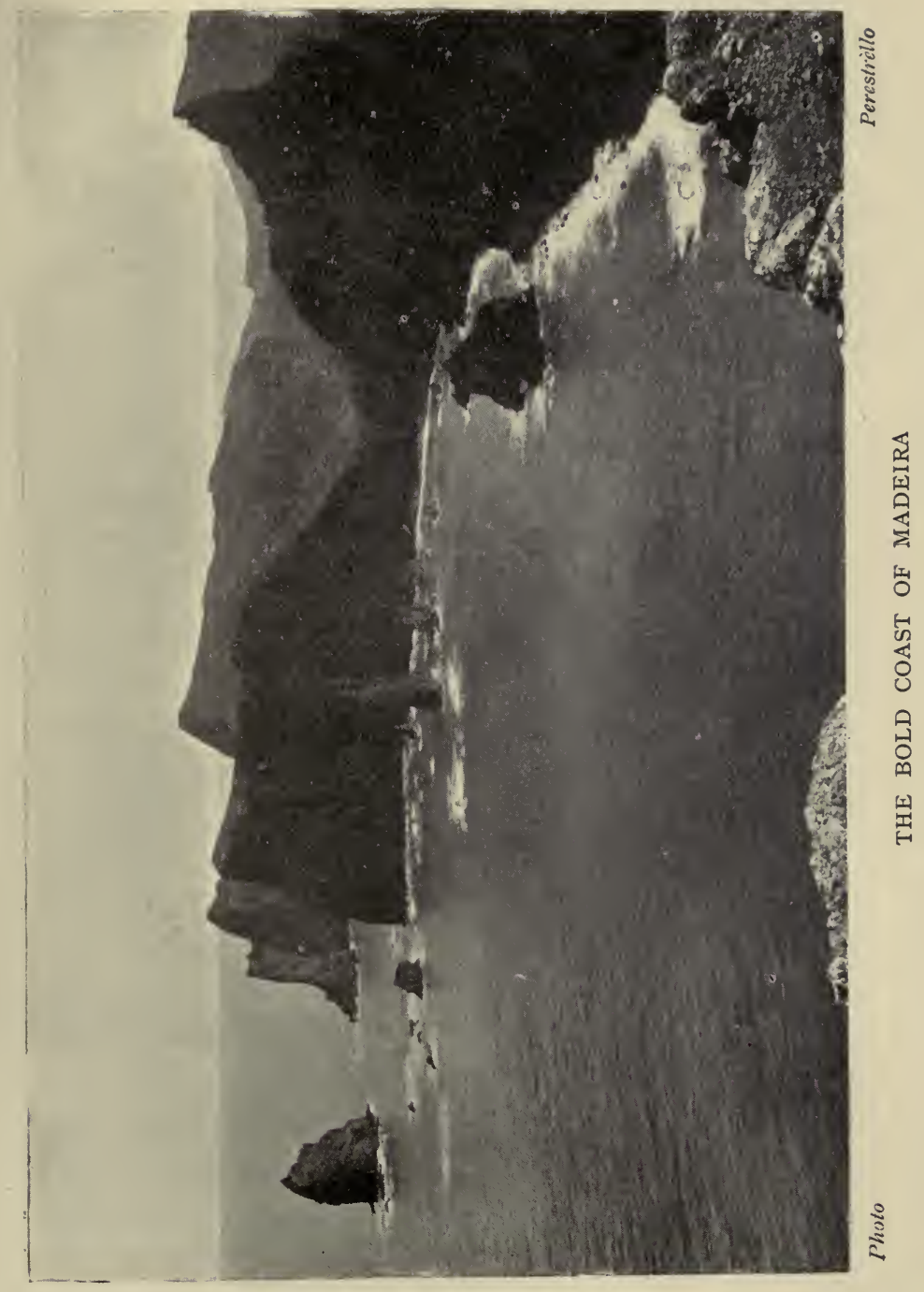


to New York in a Nova Scotia barque, the Scottish Bride. She was not copper-bottomed, and as, during her last three years in the Mediterranean she had not once been cleaned, she was very foul with barnacles. She got becalmed off Madeira on a sixty-fathom bank, and the fish rose in hundreds after the barnacles, were caught in great number by the crew, and followed the vessel almost as far as the American coast.

It cannot be said that this unsophisticated behaviour is what I should have expected of tunny after my experiences off Madeira and Porto Santo, but education may have done something for them, as it has for most fish in both fresh and salt, during the last few years. It may be also that on some future occasion I shall catch them in more friendly mood. If not I, someone else. It matters very little, so long as the thing is done. 
HÆC OLIM MEMINISSE JUVABIT 



\section{IX}

\section{HÆC OLIM MEMINISSE JUVABIT}

The Margate mullet and Madeira tunny, the mullet that were, the tunny that were not, have swum to the very shore of retrospect, for the summer that is gone completes the quarter of a century. Between those Lowestoft quays in 1880 and the Kentish pier in 1905 memory has ranged over strange phantasy of hot seas and cold, and heaving ocean and peaceful estuary.; days and nights on piers, bridges, beaches, lighthouses ; summer solstice north of the Equator; and south of it, winter months, that should be summer to anyone so accustomed. Of fishing-craft reminiscence embraces such a medley as links the Berthon, which we carried shoulder-high to the water's edge, and the ten-thousand-ton liner flying the burgee of the Union-Castle company. These and other pictures shape themselves at bidding, some sharp in outline, others blurred and defiant of closer inspection. As the old scenes are revisited, the old battles fought again, half a dozen languages, with as many more dialects, echo in the ear. Now and then the mind's eye spells out some weird, uncouth word like Köder, Machiowler, Chut, and. 
automatically each conjures up its appropriate human figure, the scarred German student, the weather-beaten Cornishman, the gaunt Asiatic, transplanted to another soil, who worships in the Mosque. Scarcely a bait, but recalls a seascape in keeping; the sunlit Devon estuary for the sand-eel, the chalky line of Kent for the rockworm and for paste, the uncovered Cornish harbour for the pilchard, the last a memory rather for the nose.

A pleasant task is done. The persistent personal note, which may, I fear, have embroiled me with reviewers hitherto more than kind, was explained at the threshold. A respected friend, to whom some earlier portions of the book were submitted, took exception to the title. He was indignant, in short, that the salt of a man's life should be associated with "so silly an ideal as "fish-killing, which puts you on a level with otters " and porpoises, or rather below them, since they " kill more fish in a week than you in a year.

" as an occasional diversion for idle hours, perhaps, "but as the salt of life. ...!"

Yet retrospect is not sweetened only by memories of the slain, nor is the salt of life necessarily synonymous with its ideals. The failures survive with the successes; to each the due niche. The quaint restfulness of Poole is not spoilt for me because I caught no bass from its bridge. For 


\section{HAC OLIM MEMINISSE JUVABIT 273}

all its lack of fish, the picturesque stagnation of Maldon has left a pleasant memory. I never caught a mullet in the Arun, or a tunny anywhere, yet that comely Sussex river, flowing through lush meadows, from castle to pier, is as glad a retrospect as the Atlantic islands where in vain I sought the mightiest game in the angler's visiting list.

It may be that the story of the manner in which a man has employed his leisure reads the riddle of his failure in the sterner purposes of life. Indeed, the measure of that leisure may furnish the explanation. Yet he will not hug its memory the less. If from time to time he looks with envy at the winners in life's race, who were his equals, almost perhaps his inferiors, in the days of school, consolation comes with the conviction that he has had, if a less profitable, at any rate a more enjoyable time of it here below. Reflection may also bring the blessed revelation that failure and success are but relative, that yesterday's disappointment is the solace of to-morrow, that there are as good fish in the sea as ever came out of it.

Only a few weeks ago I saw the chequered buoy which revolves in conflicting currents a little way outside the entrance to Ramsgate Harbour, saw its black-and-white shell with a friendly eye. Yet for many years I could not look upon it without resentment, for the suspicion rankled $19-(2272)$ 
that a week of May squandered in its company in 1889 might, spent in the smell of oil, have given another result in June. And then came the assurance of that blessed Anglo-Indian that the goal

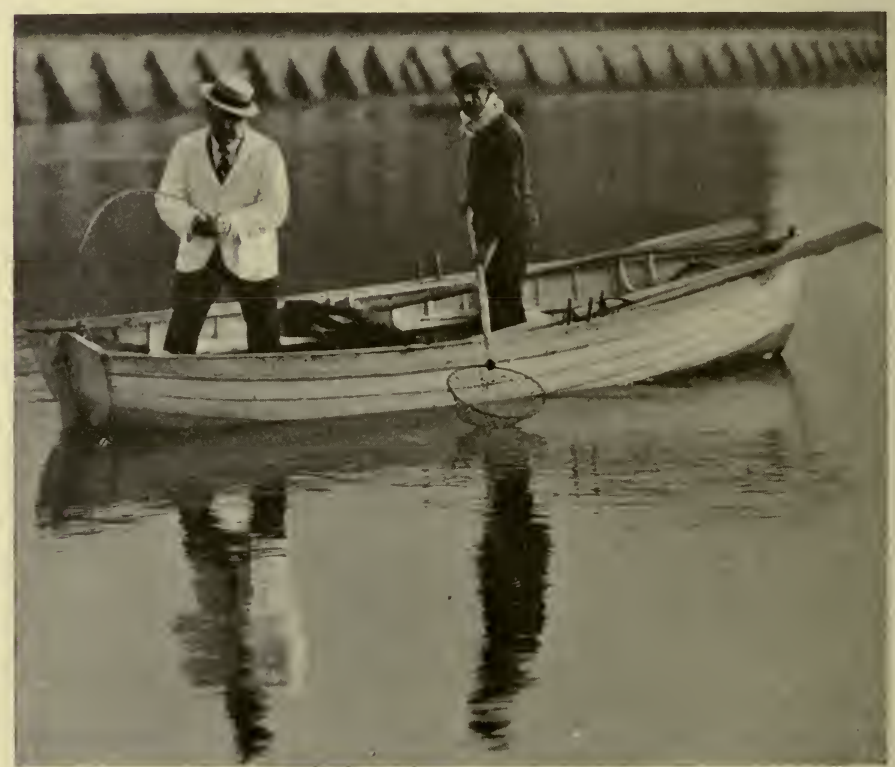

NEARING THE END

of my ambitions sixteen years ago would ere now have been my tomb-and the buoy is forgiven. There is a gentle river in the soft West country, more than once referred to in these pages, whereon one evening I sat idly angling, when a messenger 


\section{HÆC OLIM MEMINISSE JUVABIT 275}

ran along the quay waving the pink slip that told me of an action lost in the House of Lords. Had the intelligence found me on shore, I should doubtless have gone to the telegraph office and wired condolences to the public-spirited Society which had fought on purely technical grounds an action, with which my personal connection was little more than nominal. This remarkable reversion of two findings in the Court below would, I knew, inevitably entail on the Society in question a heavy loss, which I felt far more than the mere personal annoyance of so unlooked for a result. I might, but for the blessed disability of being in a boat, have written off the reel some absurd letter to the Times, which that journal would not have published. What? The tide was flowing; the bass were on the feed. To perdition with copyright and all the far off turmoil of the great world ! To limbo with the lawyers; to purgatory. with the publishers! On went a fresh bait, and next moment I was absorbed in a struggle so vigorous as to banish all thought of my lost suit. I even forgot to cry "Down with the House of Lords!" By the time two more bass had been added to the five already in the boat, the tide was at the full, and I stepped ashore in a chastened mood, which realised that, whether justice had been done or not, the heavens were not falling.

Some there are who regard angling and kindred 
pursuits as proper rather to the period of extreme youth, when the broader purposes of life have not been seriously engaged in. This is a fallacy, for one of its strongest claims on the devotee is its potence as an elixir of youth. The keen angler is always young, and even when rheumatism and other legacies of the years that lie behind debar him from kneeling in wet grass to stalk his trout, or from staying on the water on any but the warmest days, the memories of more robust sport bring with them a measure of consolation.

The angler has indeed an advantage over the devotees of most other sports and, games. The shooting man is compelled by the march of years to confine himself to the grouse butts or coverts, for the exercise of rough shooting and walking generally is too much for all but the hardiest when life is over the brink of the hill. The cricketer the footballer, the polo player are, in the process of years, reduced to the position of lookers on. Golf, it is true, affords gentle exercise for even an octogenarian; and the man who can take croquet seriously in his youth could probably do as much on his hundredth birthday.

It is borne home to some of us, who, from force of circumstances or by inclination, work hard in other directions, that the old interest in our fishing sometimes palls; and we realise with regret that our loyalty, which no failure would have 


\section{HÆC OLIM MEMINISSE JUVABIT 277}

undermined twenty years ago, needs feeding with continual success.

The pity of it !

It is well for the fisherman whose sport still holds first place in his affections when time, or his own temper, has robbed him of his friends.

For me, when the salt shall have lost its savour, let them ring down the curtain.

The play will be ended.

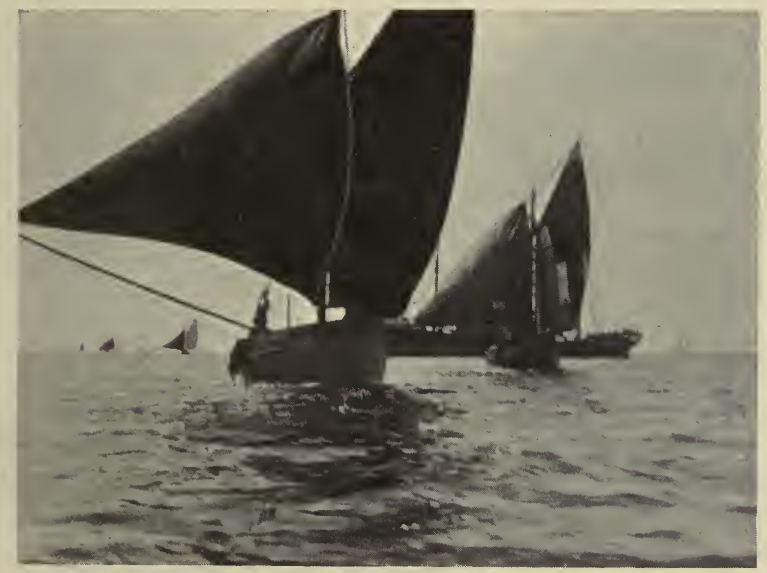




